\title{
Terrestrial Salamander and Ant Community Responses to Imidacloprid Application in Central Appalachian Eastern Hemlock Forests
}

\author{
Lenza E. Paul
}

West Virginia University, lep0001@mix.wvu.edu

Follow this and additional works at: https://researchrepository.wvu.edu/etd

\author{
Recommended Citation \\ Paul, Lenza E., "Terrestrial Salamander and Ant Community Responses to Imidacloprid Application in \\ Central Appalachian Eastern Hemlock Forests" (2021). Graduate Theses, Dissertations, and Problem \\ Reports. 10259. \\ https://researchrepository.wvu.edu/etd/10259
}

This Thesis is protected by copyright and/or related rights. It has been brought to you by the The Research Repository @ WVU with permission from the rights-holder(s). You are free to use this Thesis in any way that is permitted by the copyright and related rights legislation that applies to your use. For other uses you must obtain permission from the rights-holder(s) directly, unless additional rights are indicated by a Creative Commons license in the record and/ or on the work itself. This Thesis has been accepted for inclusion in WVU Graduate Theses, Dissertations, and Problem Reports collection by an authorized administrator of The Research Repository @ WVU. For more information, please contact researchrepository@mail.wvu.edu. 
Terrestrial Salamander and Ant Community Responses to Imidacloprid Application in Central Appalachian Eastern Hemlock Forests

Lenza E. Paul

Thesis submitted to the Davis College of Agriculture, Natural Resources, and Design

at West Virginia University

in partial fulfillment of the requirements for the degree of

Master of Science

in

Wildlife and Fisheries Resources

Donald J. Brown, Ph.D., Chair

Petra B. Wood, Ph.D.

Yong-Lak Park, Ph.D.

Division of Forestry and Natural Resources

Wildlife and Fisheries Resources Program

Morgantown, West Virginia

2021

Keywords: ants, Appalachia, eastern hemlock, eastern red-backed salamander (Plethodon cinereus), hemlock woolly adelgid (Adelges tsugae), imidacloprid, pesticide, salamander, wildlife

Copyright 2021 Lenza E. Paul 


\section{ABSTRACT \\ Terrestrial Salamander and Ant Community Responses to Imidacloprid Application in Central Appalachian Eastern Hemlock Forests}

Lenza E. Paul

Imidacloprid is the most widely used insecticide in the world and has been found to impact non-target taxa in systems in which it is applied. It is used as the primary treatment method in the protection of eastern hemlocks (Tsuga canadensis) from impacts of hemlock woolly adelgid (HWA; Adelges tsugae), an invasive insect in the U.S. that is causing widespread mortality of hemlock trees. In this study, we investigated whether imidacloprid applied in eastern hemlock forests is impacting woodland salamander and ant communities.

In Chapter 1, I provide an overview of the ecological importance of eastern hemlocks and the HWA invasion, with a focus on invasion and management responses in the West Virginia National Park system. I then discuss biological and ecological aspects of the pesticide imidacloprid the ecological importance of eastern hemlocks, followed by a review of potential impacts of imidacloprid on amphibians and ants. Finally, I introduce the study area, discuss research needs, and define the objectives of the thesis research.

In Chapter 2, we investigated whether imidacloprid applications were associated with woodland salamander abundance and health. We sampled terrestrial salamander communities at 18 control and treatment sites, respectively, with $12-17$ surveys completed at each site. We tested the influence of three imidacloprid predictors on relative abundance and body condition while accounting for influential habitat characteristics. We did not find evidence for an overall 
difference in relative abundance between control and treatment plots. The body condition index score of adult salamanders was negatively associated with treated tree diameter at breast height (DBH), a proxy for treatment intensity, and positively associated with years since treatment (YST) at treatment sites. Furthermore, the YST relationship was stronger at sites with greater treated tree DBH. In addition, 8 eastern red-backed salamanders (Plethodon cinereus) collected from treatment areas contained imidacloprid, indicating terrestrial salamanders are uptaking the pesticide.

In Chapter 3, we investigated the influence of imidacloprid treatments in eastern hemlock forests on ant relative abundance and diversity. Using bait traps, we sampled ants at 18 control and treatment sites, respectively, in spring, summer, and fall in 2020. We captured a total of 5 species and 17,626 ants, with 10,324 ants captured in control plots and 7,302 ants captured in treatment plots. We found that relative abundance of the dominant ant species (Aphaenogaster picea) exhibited a strong negative response to imidacloprid treatments. Recovery time of the species over time was dependent on treated tree DBH and years since the plot was treated, with abundances improving faster in sites with a lower amount of treated tree DBH. We found that ant diversity was also negatively impacted by imidacloprid treatments, but the effect was weaker, with coefficient confidence intervals overlapping 0 . In addition, we detected imidacloprid in the biomass of ants collected from treatment sites, indicating ants are uptaking the pesticide.

Overall, our study indicates that woodland salamanders and ants in eastern hemlock forests are negatively impacted by imidacloprid treatments, but they seem to recover over time. Salamanders and ants heavily influence the ecology of forest systems in the eastern U.S. They serve as important predators and prey and can have direct and indirect influences on the biological, physical, and chemical properties of soil and vegetation. The results of this thesis may 
help resource managers make informed decisions to balance the need for maintaining healthy eastern hemlock forests while minimizing impacts to non-target species. 


\section{ACKNOWLEDGMENTS}

I would first like to acknowledge the support, patience, guidance, and encouragement that I have received from my research advisor Dr. Donald Brown. I want to thank my committee members Drs. Petra Wood and Yong-Lak Park for their support, guidance, and direction during this process. I would especially like to acknowledge my National Park Service supervisors, coworkers, and interns that have stood by my side through this lengthy process and have directly contributed to my research project and facilitated completion of the degree requirements. I want to thank John Perez who developed the original outline and scope of work for this project. I want to acknowledge my former supervisor Dr. Mark Graham who encouraged me to pursue my M.S. in order to advance my wildlife management career. I want to give a special acknowledgment to my current supervisor, Bryan Wender, who has patiently supported me through this process, offering encouragement and motivation for me to see it to completion in my times of self-doubt. I'd like to express my gratitude to Sara Crayton, who not only provided technical support throughout my research, but was a crucial source of emotional support and motivation as well. Lastly, I want to express my love and appreciation to my motley crew of animals that are the unknowing source of my mental stability and happiness. 


\section{TABLE OF CONTENTS}

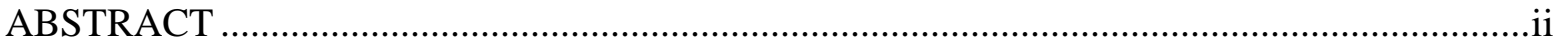

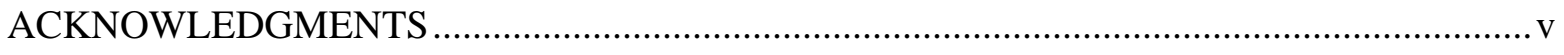

TABLE OF CONTENTS ................................................................................................

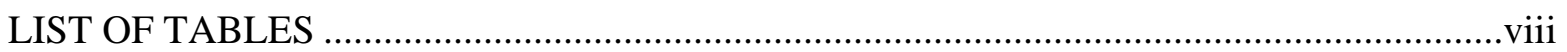

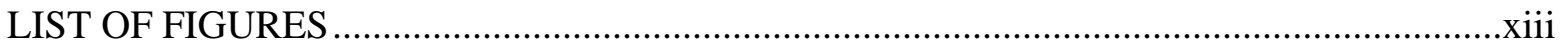

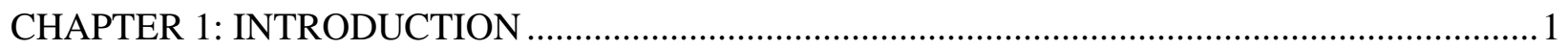

HEMLOCK WOOLLY ADELGID MANAGEMENT IN THE WEST

VIRGINIA NATIONAL PARK SYSTEM ………………………………………………...

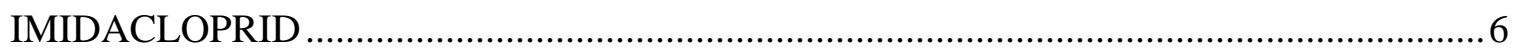

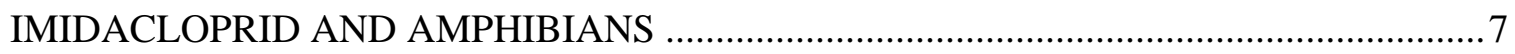

IMIDACLOPRID AND ANTS ..................................................................................

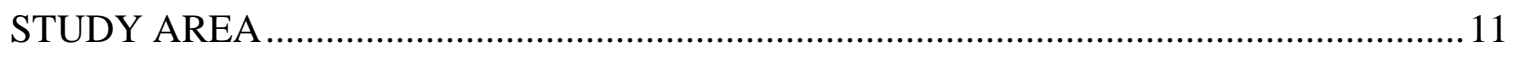

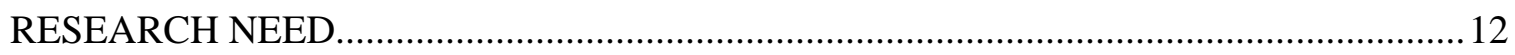

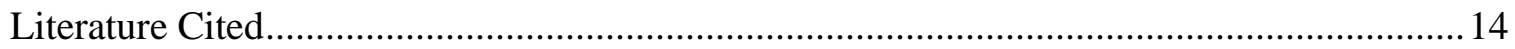

CHAPTER 2: EFFECTS OF IMIDACLOPRID EXPOSURE ON WOODLAND

SALAMANDER RELATIVE ABUNDANCE AND HEALTH...................................................22

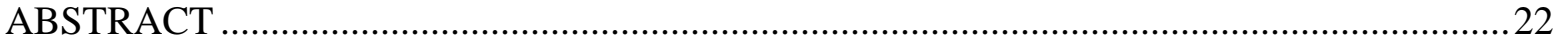

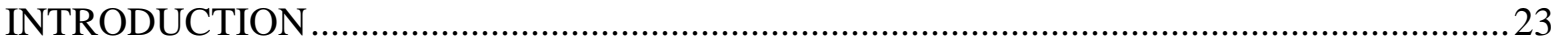

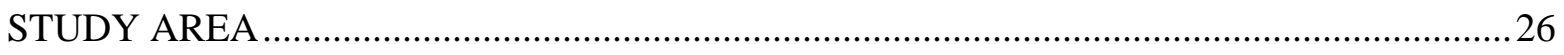

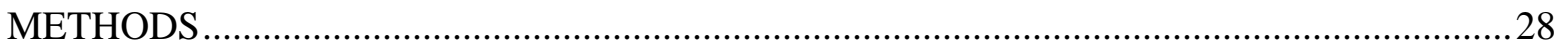

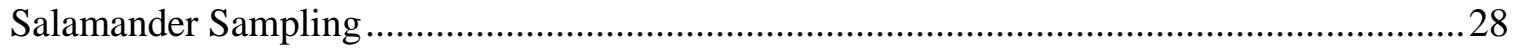

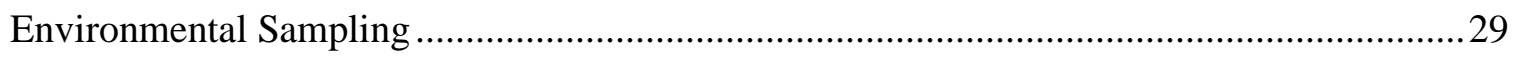

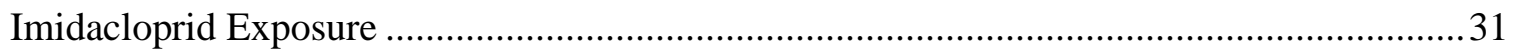

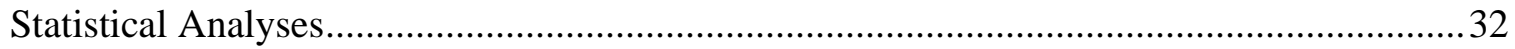

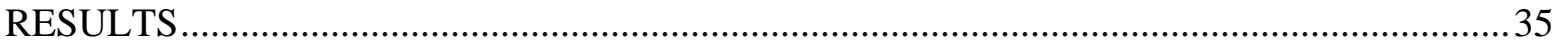

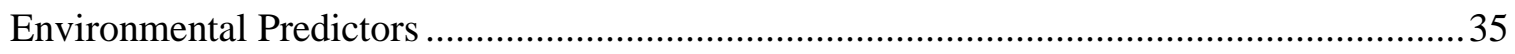

Imidacloprid Effects (Control and Treatment Plots) ............................................................36 


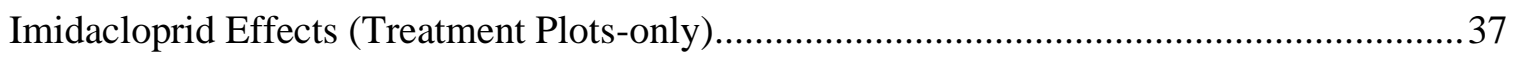

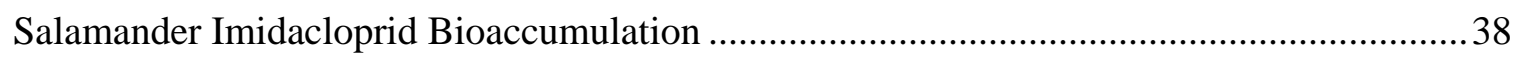

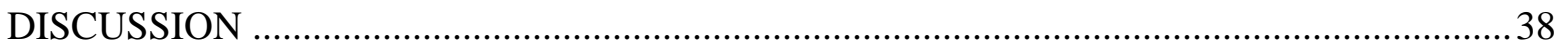

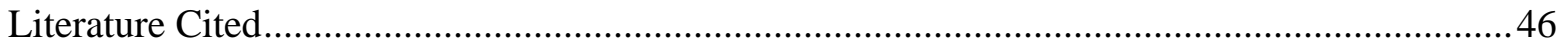

CHAPTER 3: EFFECT OF IMIDACLOPRID TREATMENTS IN EASTERN

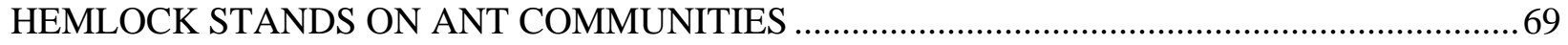

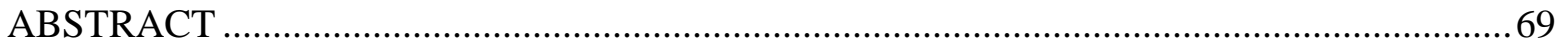

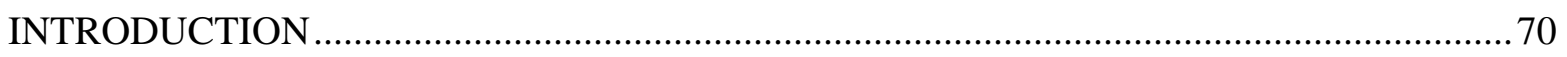

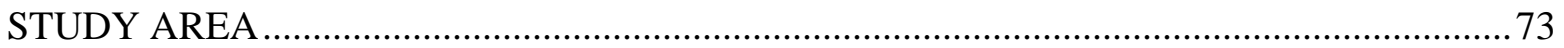

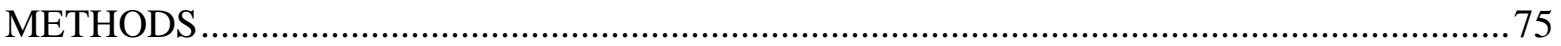

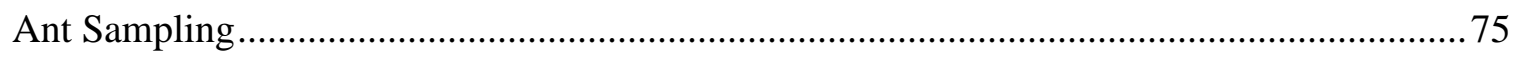

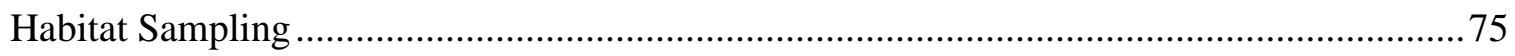

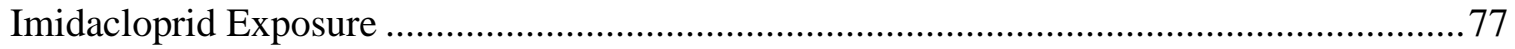

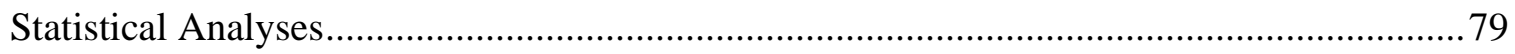

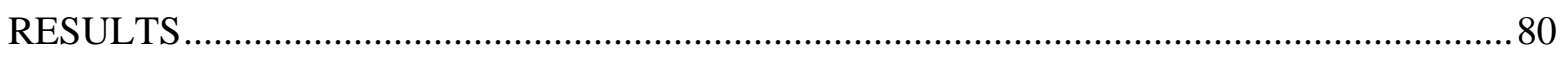

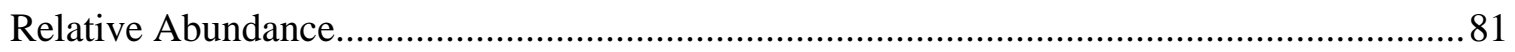

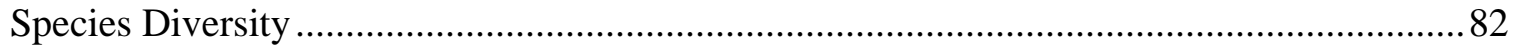

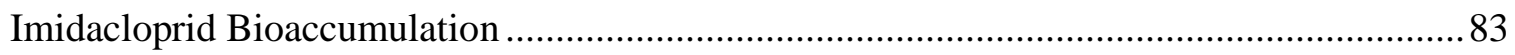

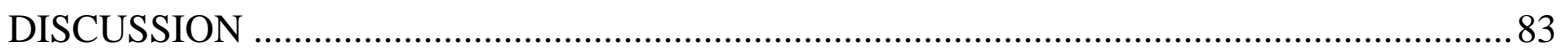

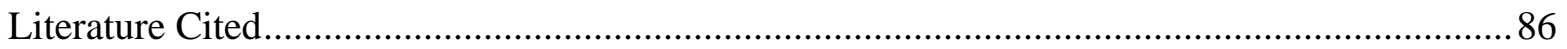




\section{LIST OF TABLES}

\section{CHAPTER 1}

Table 1-1. Imidacloprid treatment details for the history of eastern hemlock (Tsuga canadensis) conservation efforts in Gauley River National Recreation Area and New River Gorge National River in West Virginia, USA. Imidacloprid was applied as a soil drench, soil tablet, or a trunk injection to protect the trees from the impacts of hemlock woolly adelgid (Adelges tsugae)..... 21

\section{CHAPTER 2}

Table 2-1. Total detections and captures-per-unit effort (CPUE) of each salamander species captured in terrestrial plots located in eastern hemlock (Tsuga canadensis) forests that have been treated or not been treated with imidacloprid. Plots were located in Gauley River National Recreation Area and New River Gorge National River, West Virginia, USA. For each species and life stage, CPUE was calculated by dividing total detections by the total number of surveys per plot, and then averaging across plots. Standard deviation (SD) is displayed next to CPUE. Species are ordered from the highest number of detections to the lowest. Plethodon cinereus and Plethodon glutinosis were separated by adults and juveniles for further analysis, while the other species were not separated into age classes or analyzed due to low detections.

Table 2-2. Imidacloprid (IMI) concentrations in soil samples extracted from terrestrial salamander plots located in eastern hemlock (Tsuga canadensis) forests that have been treated (Tx) or not treated with imidacloprid. Plots were located in Gauley River National Recreation Area and New River Gorge National River, West Virginia, USA. Dashes represent samples in which no imidacloprid or metabolites were detected. Site codes that end in " $T$ " indicate a treatment site, while codes ending in " $\mathrm{C}$ " indicate control sites

Table 2-3. Control and treatment plot model selection results for the influence of environmental variables on terrestrial salamander captures-per-unit-effort (CPUE) in eastern hemlock (Tsuga canadensis) forests in Gauley River National Recreation Area and New River Gorge National River, West Virginia, USA. Sample groups consisted of adult Plethodon cinereus (Adult PLCI; $\mathrm{n}$ $=542$ ), adult $P$. glutinosis and $P$. cinereus (Total Adults; $\mathrm{n}=577$ ), and juvenile $P$. glutinosis and $P$. cinereus (Total Juveniles; $\mathrm{n}=151$ ). Environmental variables were standardized prior to analyses and included canopy cover (\%; canopy), soil $\mathrm{pH}$ (converted to $\mathrm{H}^{+}$), soil moisture (\% volumetric water content), mean cover objects searched across all samples (cover objects), total tree diameter at breast height (total DBH), and combined duff and litter depth (cm; duff and litter depth). The intercept-only model is represented by ( . ). We ranked each candidate predictor using Akaike's Information Criterion corrected for small sample size $(\triangle \mathrm{AIC} c)$ and included additive and interaction candidate models in the model selection for the two most supported predictors 
Table 2-4. Control and treatment plot model selection results for the influence of environmental variables on terrestrial salamander body condition index (BCI) scores in eastern hemlock (Tsuga canadensis) forests in Gauley River National Recreation Area and New River Gorge National River, West Virginia, USA. Sample groups consisted of adult Plethodon cinereus (Adult PLCI; $\mathrm{n}$ = 536), adult $P$. glutinosis and $P$. cinereus (Total Adults; $\mathrm{n}=571$ ), and juvenile $P$. glutinosis and $P$. cinereus (Total Juveniles; $\mathrm{n}=149$ ). Environmental variables were standardized prior to analyses and included canopy cover (\%; canopy), soil $\mathrm{pH}\left(\right.$ converted to $\left.\mathrm{H}^{+}\right)$, soil moisture (\% volumetric water content), mean cover objects searched across all samples (cover objects), total tree diameter at breast height (total DBH), and combined duff and litter depth (cm; duff and litter depth). The intercept-only model is represented by ( . ). We ranked each candidate predictor using Akaike's Information Criterion corrected for small sample size $(\triangle \mathrm{AIC} c)$ and included additive and interaction candidate models in the model selection for the two most supported predictors.

Table 2-5. Control and treatment plot model selection results for the influence of imidacloprid variables on terrestrial salamander captures-per-unit-effort (CPUE) and body condition index (BCI) scores in eastern hemlock (Tsuga canadensis) forests in Gauley River National Recreation Area and New River Gorge National River, West Virginia, USA. Sample groups consisted of adult Plethodon cinereus (Adult PLCI), adult $P$. glutinosis and $P$. cinereus (Total Adults), and juvenile $P$. glutinosis and $P$. cinereus (Total Juveniles). Imidacloprid variables included total treated tree diameter at breast height (Tx Tree $\mathrm{DBH})$ standardized before analysis and treatment presence (a categorical variable representing whether the site was located in a treated or nontreated area; Tx Presence). The intercept-only model is in parentheses and included top environmental predictors from the first stage of the model selection process (Table 2-3 and 2-4). We ranked each imidacloprid predictor using Akaike's Information Criterion corrected for small

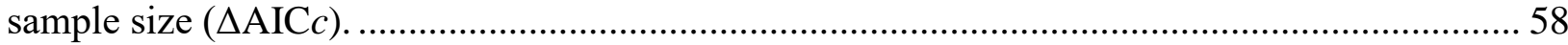

Table 2-6. Model coefficient ( $\beta$ ) estimates and 85\% confidence intervals (CI) for supported control and treatment plot models investigating potential sublethal effects of imidacloprid on salamander captures-per-unit-effort (CPUE) and body condition index (BCI) scores in eastern hemlock (Tsuga canadensis) forests in Gauley River National Recreation Area and New River Gorge National River, West Virginia, USA. Sample groups consisted of adult Plethodon cinereus (Adult PLCI), adult $P$. glutinosis and $P$. cinereus (Total Adults), and juvenile $P$. glutinosis and $P$. cinereus (Total Juveniles). Imidacloprid variables were standardized prior to analyses and included total treated tree diameter at breast height (Tx Tree DBH) and treatment presence (a categorical variable representing whether the site was located in a treated or nontreated area; Tx Presence). Imidacloprid predictors defined in the table represent imidacloprid variables with Akaike's Information Criterion corrected for small sample size ( $\triangle \mathrm{AIC} c$ ) scores of

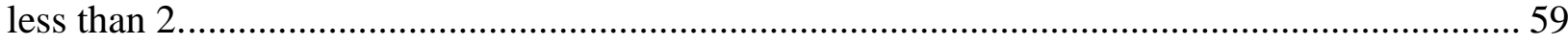

Table 2-7. Total detections and mean body condition index (BCI) of Plethodon cinereus and $P$. glutinosis individuals captured over 516 terrestrial salamander surveys conducted to investigate potential sublethal effects of imidacloprid on salamanders in West Virginia, USA. 
Table 2-8. Treatment plots-only model selection results to determine the potential effects of imidacloprid on salamander captures-per-unit-effort (CPUE) and body condition index (BCI) scores in eastern hemlock (Tsuga canadensis) forests in Gauley River National Recreation Area and New River Gorge National River, West Virginia, USA. Sample groups consisted of adult Plethodon cinereus (Adult PLCI), adult P. glutinosis and P. cinereus (Total Adults), and juvenile $P$. glutinosis and $P$. cinereus (Total Juveniles). Imidacloprid variables were standardized and included mean years since treatment (YST) and total treated tree diameter at breast height (Tx Tree DBH). Total treated tree DBH and YST were tested together as both an additive (+) and interaction (x) effect. The intercept-only model is in parentheses and included top environmental predictors (Table 2-3 and 2-4). We ranked each candidate predictor using Akaike's Information Criterion corrected for small sample size $(\triangle \mathrm{AIC} c)$.

Table 2-9. Model coefficient ( $\beta$ ) estimates and 85\% confidence intervals (CI) for supported treatment plots-only models in this study investigating potential sublethal effects of imidacloprid on salamander captures-per-unit-effort (CPUE) and body condition index (BCI) scores in eastern hemlock (Tsuga canadensis) forests in Gauley River National Recreation Area and New River Gorge National River, West Virginia, USA. Sample groups consisted of adult Plethodon cinereus (Adult PLCI), adult $P$. glutinosis and $P$. cinereus (Total Adults), and juvenile $P$. glutinosis and $P$. cinereus (Total Juveniles). Imidacloprid variables were standardized prior to analyses and included mean years since treatment (YST), and total treated tree diameter at breast height (Tx Tree DBH). Total treated tree DBH and YST were tested together as both an additive $(+)$ and interaction $(x)$ effect. Imidacloprid predictors defined in the table represent imidacloprid variables with Akaike's Information Criterion corrected for small sample size ( $\triangle \mathrm{AIC} c$ ) scores of less than 2

Table 2-10. Imidacloprid concentrations found in eight adult Plethodon cinereus collected in $2018(n=4)$ and $2019(n=4)$ in treated eastern hemlock (Tsuga canadensis) forests in Gauley River National Recreation Area and New River Gorge National River, West Virginia, USA. Individuals were analyzed separately using liquid chromatography-tandem mass spectrometry for presence of imidacloprid. Surrogate recovery is a measurement of analysis accuracy. A recovery score of $100 \%$ represents an analysis with no error, while percentages less than or more than 100 represent surrogate recovery with some error.

\section{CHAPTER 3}

Table 3-1. Total ant captures by species, captures-per-unit-effort (CPUE), and Simpson's diversity index for control and treatment plots located in treated or untreated eastern hemlock (Tsuga canadensis) forests in Gauley River National Recreation Area and New River Gorge National Park and Preserve, West Virginia, USA. Site codes that end in "T" indicate treatment plots, while codes ending in " $\mathrm{C}$ " indicate control plots. To account for uneven sampling effort, we calculated CPUE by dividing the total number of Aphaenogaster picea captures by the total number of subplot samples per plot. 
Table 3-2. Imidacloprid (IMI) and two common imidacloprid metabolite (IMI Olefin, IMI Urea) concentrations in soil samples extracted from eastern hemlock (Tsuga canadensis) forests that were used to investigate the effects of imidacloprid on ant abundance and species diversity in Gauley River National Recreation Area and New River Gorge National Park and Preserve, West Virginia, USA. Dashes represent samples in which no imidacloprid or metabolites were detected. Site codes that end in " $\mathrm{T}$ " indicate treatment plots, while codes ending in " $\mathrm{C}$ " indicate control plots.

Table 3-3. Control and treatment plot model selection results for the influence of environmental and imidacloprid variables on Aphaenogaster picea captures-per-unit-effort (CPUE) in eastern hemlock (Tsuga canadensis) forests in Gauley River National Recreation Area and New River Gorge National Park and Preserve, West Virginia, USA. Environmental variables were standardized prior to analyses and included canopy cover (\%; canopy), soil $\mathrm{pH}$ (converted to $\mathrm{H}^{+}$), soil moisture (\% volumetric water content), total tree diameter at breast height (total DBH), and combined duff and litter depth (cm; duff and litter depth). Imidacloprid variables were standardized prior to analyses and included total treated tree diameter at breast height (Tx Tree $\mathrm{DBH}$ ) and treatment presence (a categorical variable representing whether the site was in a treated or non-treated area; Tx Presence). The intercept-only model is represented by ( . ). We ranked each candidate predictor using Akaike's Information Criterion corrected for small sample size $(\triangle \mathrm{AIC} c)$ and included additive $(+)$ and interaction $(\mathrm{x})$ candidate models in the model selection for the two most supported environmental predictors.

Table 3-4. Model coefficient ( $\beta$ ) estimates, standard errors (SE) and $85 \%$ confidence intervals (CI) for supported control and treatment plots and treatment plots-only models in this study investigating potential effects of imidacloprid on Apheanogaster picea captures-per-unit-effort (CPUE) in eastern hemlock (Tsuga canadensis) forests in Gauley River National Recreation Area and New River Gorge National Park and Preserve, West Virginia, USA. Control and treatment plot imidacloprid variables were standardized prior to analyses and included total treated tree diameter at breast height (Tx Tree DBH) and treatment presence (a categorical variable representing whether the site was located in a treated or non-treated area; Tx Presence). Treatment plots-only imidacloprid variables were also standardized prior to analyses and included mean years since treatment (YST), and total treated tree diameter at breast height (Tx Tree DBH). total treated tree DBH and YST were tested together as both an additive (+) and interaction (x) effect. Models included in this table represent imidacloprid variables with Akaike's Information Criterion corrected for small sample size $(\triangle \mathrm{AIC} c)$ scores $<7$. 
Table 3-5. Treatment plots-only model selection results for the influence of environmental and imidacloprid variables on Aphaenogaster picea captures-per-unit-effort (CPUE) in eastern hemlock (Tsuga canadensis) forests in Gauley River National Recreation Area and New River Gorge National Park and Preserve, West Virginia, USA. Environmental variables were standardized prior to analyses and included canopy cover (\%; canopy), soil $\mathrm{pH}$ (converted to $\mathrm{H}^{+}$), soil moisture (\% volumetric water content), total tree diameter at breast height (total DBH), and combined duff and litter depth ( $\mathrm{cm}$; duff and litter depth). Imidacloprid variables were standardized prior to analyses and included mean years since treatment (YST) and total treated tree diameter at breast height (Tx Tree DBH). Total treated tree DBH and YST were tested together as both an additive (+) and interaction (x) effect. The intercept-only model is represented by ( . ). We ranked each imidacloprid predictor using Akaike's Information Criterion

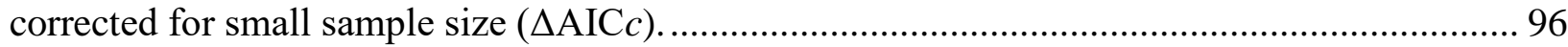

Table 3-6. Control and treatment plot model selection results, coefficient ( $\beta$ ) estimates, standard errors (SE) and 85\% confidence intervals (CI) for the influence of environmental and imidacloprid variables on ant species diversity in eastern hemlock (Tsuga canadensis) forests in Gauley River National Recreation Area and New River Gorge National Park and Preserve, West Virginia, USA. The response variable was Simpson's diversity index calculated for each plot. Environmental variables included canopy cover (\%; canopy), soil $\mathrm{pH}$ (converted to $\mathrm{H}^{+}$), soil moisture (\% volumetric water content), total tree diameter at breast height (total DBH), and combined duff and litter depth (cm; duff and litter depth). Imidacloprid variables included total treated tree diameter at breast height (Tx Tree DBH) and treatment presence (a categorical variable representing whether the site was in a treated or non-treated area; Tx Presence). Environmental and imidacloprid variables were standardized prior to analyses. The interceptonly model is represented by $($.$) . We ranked each candidate predictor using Akaike's$ Information Criterion corrected for small sample size $(\triangle \mathrm{AIC} c)$ and included additive $(+)$ and interaction (x) candidate models in the model selection for the two most supported environmental predictors. 


\section{LIST OF FIGURES}

\section{CHAPTER 1}

Figure 1-1. General locations of research plots in New River Gorge National River (NERI) and Gauley River National Recreation Area (GARI), West Virginia, USA. The Fayetteville area has 10 research sites (Bridge Buttress, Burnwood 1, Burnwood 2, Fern Buttress, Fern Creek 1, Fern Creek 2, Fern Creek 4, Kaymoor 1, Kaymoor 2, and Nuttall sites). In southern NERI, Poll's Branch research area consists of 2 sites. The remaining 8 research sites are in GARI (upper right) and consists of Carnifex Ferry, Elliott Cutoff, Richmond Chapel, Summersville Dam 1, Summersville Dam 2, Wood's Ferry. Each site consists of a control and a treatment plot, for a total of 36 plots.

\section{CHAPTER 2}

Figure 2-1. Map of imidacloprid study sites used in this study investigating potential effects of imidacloprid on salamander relative abundance and body condition index scores in eastern hemlock (Tsuga canadensis) forests in Gauley River National Recreation Area and New River Gorge National River, West Virginia, USA. There were 18 sites consisting of a treatment plot and a control plot for a total of 36 plots sampled over a three-year period from 2016 to 2019. .. 66

Figure 2-2. Terrestrial salamander sampling plot design showing coverboard locations and soil sampling points for imidacloprid quantification during 2017-2019. Plots measured $20 \mathrm{~m}$ x $20 \mathrm{~m}$ and were installed in eastern hemlock (Tsuga canadensis) forest that had been treated or not treated with imidacloprid in Gauley River National Recreation Area and New River Gorge National River, West Virginia, USA.

Figure 2-3. Model-estimated relationship showing the effects of years since treatment (YST) and treated tree diameter at breast height (Tx Tree $\mathrm{DBH} ; \mathrm{cm}$ ) on adult Plethodon cinereus body condition index (BCI) scores in eastern hemlock (Tsuga canadensis) forests treated with imidacloprid in Gauley River National Recreation Area and New River Gorge National Park and Preserve, West Virginia, USA, including: a) estimated relationship between BCI and YST without accounting for Tx Tree DBH; b) estimated relationship between BCI and Tx Tree DBH without accounting for YST; c) estimated relationship between BCI and YST at the mean (186 $\mathrm{cm}$ ) and +/- 1 standard deviation of all plot Tx Tree DBH size (interaction effect). The results indicate that BCI was positively associated with YST and negatively associated with Tx Tree DBH, but plots with greater Tx Tree DBH had a stronger positive influence of YST. Imidacloprid variables were standardized prior to analyses but are displayed in their original units in the figure.

\section{CHAPTER 3}

Figure 3-1. Map of imidacloprid study sites used in this study investigating potential effects of imidacloprid on ant species relative abundance and diversity in eastern hemlock (Tsuga canadensis) forests in Gauley River National Recreation Area and New River Gorge National Park and Preserve, West Virginia, USA. There were 18 sites consisting of a treatment plot and a control plot, for a total of 36 plots sampled three times in 2020. 
Figure 3-2. Model-estimated influence of treated tree diameter at breast height (DBH) on Aphaenogaster picea captures-per-unit effort (CPUE) in untreated and treated eastern hemlock (Tsuga canadensis) plots in Gauley River National Recreation Area and New River Gorge National Park and Preserve, West Virginia, USA. The variable total treated tree DBH was standardized prior to analyses, but is displayed in its original units in the figure. The gray band represents the $85 \%$ confidence interval of the estimated relationship.

Figure 3-3. Model-estimated influence of imidacloprid treatment presence (Tx Presence) on Aphaenogaster picea captures-per-unit effort (CPUE) in untreated and treated eastern hemlock (Tsuga canadensis) plots in Gauley River National Recreation Area and New River Gorge National Park and Preserve, West Virginia, USA. We calculated CPUE by dividing total captures by number of subplot samples per plot.

Figure 3-4. Model-estimated relationship of the effects of years since treatment (YST) and treated tree diameter at breast height (Tx Tree DBH; $\mathrm{cm}$ ) on Aphaenogaster picea captures-perunit-effort (CPUE) in eastern hemlock (Tsuga canadensis) plots treated with imidacloprid in Gauley River National Recreation Area and New River Gorge National Park and Preserve, West Virginia, USA, including: a) estimated relationship between CPUE and YST without accounting for Tx Tree DBH; b) estimated relationship between CPUE and YST and CPUE and Tx Tree DBH (additive effect); c) estimated relationship between CPUE and YST at the mean $(186 \mathrm{~cm})$ and $+/-1$ standard deviation of all plot Tx Tree DBH sizes (interaction effect). Imidacloprid variables were standardized prior to analyses, but are displayed in their original units in the figure. The gray bands represents the $85 \%$ confidence interval of the estimated relationships. 101 


\section{CHAPTER 1: INTRODUCTION}

There are five species of hemlock (Tsuga spp.) in North America: eastern hemlock ( $T$. canadensis), western hemlock (T. heterophylla), Carolina hemlock (T. caroliniana), mountain hemlock (T. mertensiana), and a mountain and western hybrid (Taylor 1972, Natural Resources Conservation Service 2020). The range of eastern hemlock extends from the far north of eastern

Canada southward to the northern areas of Georgia and Alabama. The range extends westward to Minnesota, but the most concentrated portions of the eastern hemlock range follow the Appalachian mountain range (Brisbin 1970).

Eastern hemlock occurs in moist, well-drained, loamy, acidic soils in valleys, ridgetops, coves, steep slopes, and on the periphery of wetlands (Farjon 1990). It is generally found in mixed-species forest patches with maples (Acer spp.), beeches (Fagus spp.), and oaks (Quercus spp.). Eastern hemlock cultivates unique micro-habitat conditions. In dense hemlock forests, sunlight penetration to the understory can be as little as 1\% (Rosenthal and Wildova 2017). Hemlock litter has a high tannin content, low $\mathrm{pH}$, and high carbon to nitrogen ratio that results in very slow decomposition compared to litter of primarily deciduous forests (Finzi et al. 1998). Soils in hemlock stands have low $\mathrm{pH}$, high carbon to nitrogen ratios, and low rates of nitrogen mineralization and nitrification (Mladenoff 1987, Jenkins et al. 1999, Yorks et al. 1999, Evans 2002). Hemlocks have a very shallow root system, resulting in vulnerability to drought conditions, extreme winds, and fire (Brisbin 1970).

The hemlock woolly adelgid (Adelges tsugae; HWA) is an exotic, invasive, aphid-like insect that causes severe damage to hemlock trees (Orwig and Foster 2000). It is one of many species of piercing and sucking insects that are a threat to eastern hemlock (Buck et al. 2005, 
Dilling et al. 2007, Turcotte 2017). First detected in Richmond, Virginia in 1951, HWA is thought to have been introduced from nursery trees shipped from Asia (Gouger 1971, Cheah et al. 2004). The HWA is also established in western North America on western and mountain hemlocks, but mass mortality does not occur due to established host defenses in western species (Cheah et al. 2004).

Measuring less than $2 \mathrm{~mm}$ in length, the adelgids attach themselves to the base of hemlock needles and consume xylem ray parenchyma cells (Young et al. 1995). They feed on the cells through the winter, beginning in fall and remaining in place until early the following summer. In the U.S., HWA produce two generations per year and lack natural predators, resulting in rapid population increases (Ward et al. 2004). The destruction of the xylem structure leads to reduced vigor and crown health, and tree mortality can occur in as little as four years (McClure 1991, Souto et al. 1995, Yorks et al. 1999). Slope, elevation, aspect, and soil moisture are site-level factors that are correlated with mortality in HWA-infested stands (Souto et al. 1995, Kantola et al. 2014, Havill et al. 2016). Studies have shown HWA to spread via wind, birds, deer, and humans (McClure 1996), and the species is spreading at a rate of ca. $12.5 \mathrm{~km}$ per year (Evans and Gregoire 2007).

Impacts of HWA on hemlock forest ecosystems can be severe. Stream temperatures can be significantly higher in hemlock forests that are impacted by HWA (Rosenthal and Wildova 2017). Replacement tree species in degraded eastern hemlock forests are generally deciduous species with increased water needs, and the resulting decrease in the amount of water from the forest leeching into the stream increases water temperatures (Souto et al. 1995, Siderhurst et al. 2010, Rosenthal and Wildova 2017). Jenkins et al. (1999) found impacted hemlock forests to have a higher amount of sunlight reaching the forest floor from canopy gaps created by 
mortality, increasing organic matter desiccation, and soil temperature. Nitrogen rates at the forest floor level had a significantly higher turnover rate than sites without HWA, and the quality of the organic matter at the forest floor level was negatively impacted by HWA infestation (Jenkins et al. 1999).

Current treatments for HWA infestation include chemical insecticide application (McClure 1991), horticultural foliar oil application (McClure et al. 1996), and biological controls such as entomopathogenic fungi and predatory beetles (Cheah et al. 2004). Chemical controls include active ingredients such as imidacloprid, acetamiprid, thiamethoxam, and dinotefuran (Havill et al. 2016, Turcotte 2017). Imidacloprid applied to the soil near the base of the trunk has proven to be the most effective, cost-efficient way to treat HWA populations (Cowles et al. 2005, 2006, Havill et al. 2016), though residual chemical in the soil and sap of the tree can remain for years (Havill et al. 2016). There are three main genera for biological control species that feed on HWA: Sasajiscymnus, Scymnus, and Laricobius (Sasaji and McClure 1997, Cheah et al. 2004, Cowles et al. 2006). Factors that limit the realistic field applications for biological controls include the extreme labor intensity of raising lab-reared beetles and the slow reproduction rates of the beetles (Onken and Reardon 2008).

\section{HEMLOCK WOOLLY ADELGID MANAGEMENT IN THE WEST VIRGINIA NATIONAL PARK SYSTEM}

Hemlock forests make up a large portion of the total forested area in West Virginia's National Park Service (NPS) units: New River Gorge National River (NERI), Gauley River National Recreation Area (GARI), and Bluestone National Scenic Area (BLUE; Figure 1-1). These forests play critical roles in ecological, aesthetic, and recreational aspects of each park, and compose ca. 
$5 \%$ of NERI, $8 \%$ of BLUE, and $50 \%$ of GARI total forest cover (Vanderhorst et al. 2007). In GARI, several hemlock tree stands are between 300 and 400 years old. All three parks' hemlock trees are considered highly vulnerable to the HWA.

In 1998, in response to hemlock mortality at other central Appalachian NPS units (i.e., Blue Ridge Parkway, Great Smoky Mountains National Park), NERI developed a long-term hemlock ecosystem monitoring program. Thirty-six plots were established to monitor the extant hemlock forest and its inevitable decline from HWA. Presence or absence of HWA was recorded, along with individual plot tree characteristics: live crown ratio, vigor, and tree straightness (Wood 1999). The hemlock plots remained free of HWA until 2005 (Wood et al. 2008), and by the year 2010 HWA had spread to all 36 plots. In 2000, the average hemlock crown vigor (a visual assessment of the health of the tree crown) was $95.3 \%$, with $8 \%$ hemlock mortality occurring in the plots (Onken et al. 1994, Wood et al. 2008, Strickler 2012). By 2012, average crown vigor ratings across the 36 plots had decreased to $53.5 \%$ with $24 \%$ hemlock mortality (Strickler 2012).

Control measures at West Virginia NPS units were initiated in 2005, beginning with the release of predatory beetles (primarily Laricobius nigrinus) in select hemlock stands in NERI and GARI. Park managers chose to implement L. nigrinus due to the availability of the beetles, and the success rate it has against HWA (Onken and Reardon 2008, Strickler 2012). In 2006, NPS began systemic insecticide (e.g., imidacloprid) treatments. From 2006-2018, there were a total of 15,592 applications of imidacloprid in NERI, 4,443 in GARI, and 753 in BLUE. The four treatment methods used were trunk injection, soil tablet, soil drench, and basal bark treatment. Soil drench (products: Imida ${ }^{\circledR} 75$ WSP, Merit ${ }^{\circledR} 75$ WSP, Mallet ${ }^{\circledR} 75$ WSP) was used for $51 \%$ of total treatments and was the most common method used over all treatment years. Soil 
tablets (product: Coretect $^{\circledR}$ ) account for $46 \%$ of total treatment methods, while basal bark $\left(\right.$ Safari $\left.^{\circledR}\right)$ and trunk injection (products: ImaJet ${ }^{\circledR}$, Tree-Age $^{\circledR}$ ) combined account for approximately 3\%. Between 2006 and 2018, there were approximately 544 ha of hemlock forest treated (441 ha in NERI, 95 ha in GARI, and 8 ha in BLUE). Application methods and dosage rates followed instructions on the pesticide labels. Soil drench and soil tablet application occurred at the base of the trunk to maximize uptake by the target tree (Cowles et al. 2006). Imida $^{\circledR} 75$ WSP, Merit ${ }^{\circledR} 75$ WSP, and Mallet ${ }^{\circledR} 75$ WSP are water soluble packets that contain $75 \%$ imidacloprid and are mixed with water to be used in a handheld soil injector tank. The yearly acreage limit is 8.6 ounces of active ingredient per acre per year. Coretect ${ }^{\circledR}$ tablets weigh 2.5 grams ( 0.0875 ounces) each and contain $0.5 \mathrm{~g}$ (20\%) imidacloprid. The yearly acreage limit is 450 tablets (39 ounces active ingredient) per acre per calendar year. The number of trees treated with Coretect ${ }^{\circledR}$ in all treatment sites per year in NERI and GARI ranged from 1-646 trees (mean $=96$ trees). The number of trees treated with soil drench methods in all treatment sites per year in NERI and GARI ranged from $41-3,137$ trees (mean $=968$ trees). Soil drench was the dominant treatment method in the earlier years of the treatment program. From 2006 to 2010, the mean number of trees treated annually with soil drench was 1,876 trees. From 2011 to 2018, the mean number of trees treated via soil drench dropped to 158 trees. In 2011, pesticide applicators started using more Coretect ${ }^{\circledR}$ and the mean number of trees treated with Coretect $^{\circledR}$ per year went from 103 trees (2006-2010) to 1,149 trees (2011-2018). In 2017, NERI began using an optimized treatment method developed by Benton et al. (2016) that reduced the amount of imidacloprid applied per tree for larger trees while maintaining the effectiveness of the treatment. 


\section{IMIDACLOPRID}

Imidacloprid (1-[6-chloro-3-pyridinyl) methyl]-N-nitro-2-imidazolidinimine) is a systemic pesticide that is widely used on a variety of plants for protection against sap-sucking insects. It is a neurotoxicant that causes mortality by interfering with the transmission process of the nicotinic acetylcholine receptors of the insect's nervous system (Schroeder and Flattum 1984). It deteriorates slowly causing incessant interruptions in the nervous system within the insect, most often leading to death (Schroeder and Flattum 1984, Mullins 1993, Smith and Krischik 1999). Due to the effectiveness on a wide variety of insects, it is one of the most widely used insecticides in the world (Silcox 2002, Jeschke and Nauen 2008).

Imidacloprid is considered both a systemic (distributed through the plant tissue) and a contact (causes insect mortality through direct contact) insecticide (Mullins 1993). Various studies have examined the effect of treatment season (Dilling et al. 2010), application method (Tattar et al. 1998, Cowles et al. 2006), and the movement of imidacloprid in eastern hemlocks infested with HWA (Eisenback et al. 2009, Dilling et al. 2010). Turcotte et al. (2017) demonstrated within-tree movement of imidacloprid can be intermittent depending on a variety of tree and site characteristics (i.e., tree diameter, amount of live tree crown, treatment season, and level of HWA infestation). In soils, the half-life of imidacloprid has been documented between 29 and 229 days, and tends to increase with higher soil $\mathrm{pH}$ values, absence of sunlight, and higher soil organic matter content (Sarkar et al. 2001, Fossen 2006, Liu et al. 2006, Dilling et al. 2007). 


\section{IMIDACLOPRID AND AMPHIBIANS}

Most previous research examining imidacloprid effects on amphibians involved anurans (mostly tadpoles) in laboratory settings, little research has been conducted on salamanders. Specific skin function, metabolic rates, mobility, and habitat selection are obvious differences between caudates and anurans that highlight the need for salamander-specific laboratory and field studies examining responses to imidacloprid exposure. Many of the studies called for further study on the indirect and direct effects of pesticides on amphibians, both terrestrial and aquatic (PérezIglesias et al. 2014, Van Meter et al. 2015).

To my knowledge, seven published studies have investigated imidacloprid effects on anurans, including six laboratory studies involving tadpoles (Julian 2000, Feng et al. 2004, Ade et al. 2010, Pérez-Iglesias et al. 2014, Ruiz de Arcaute et al. 2014, Hrynyk et al. 2018), two laboratory studies involving adults (Feng et al. 2004, Van Meter et al. 2015), and an outdoor mesocosm experiment involving terrestrial adults (Robinson et al. 2017). In addition, Julian (2000) tested the hatching success and development of Jefferson salamander (Ambystoma jeffersonium) egg masses exposed to four concentrations of imidacloprid and found a reduced survival probability and an increased amount of time to metamorphosis. Researchers in six of the seven studies labeled the imidacloprid concentration used in their study as unlikely to occur in the field. However, many of the studies still resulted in negative effects (Pérez-Iglesias et al. 2014, Ruiz de Arcaute et al. 2014). For example, Ruiz de Arcaute et al. (2014) and Pérez-Iglesias et al. (2014) observed genotoxic effects such as an increase in micronuclei, altered nuclei shape, and binucleated cells in Montevideo tree frogs (Hypsiboas pulchellus) exposed to imidacloprid. The two studies represented the lowest laboratory study concentrations involving imidacloprid and ranged from $52.6 \mathrm{mg} / \mathrm{l}$ (Pérez-Iglesias et al. 2014) to $84.9 \mathrm{mg} / \mathrm{l}$ (Ruiz de Arcaute et al. 2014). 
Pérez-Iglesias et al. (2014) hypothesized that imidacloprid was not a potent DNA damaging agent because the dosage required to induce micronuclei formation was presumably unrealistic for concentrations in the field. However, Ruiz de Arcaute et al. (2014) proposed a label of "moderate ecotoxicity concern" for the insecticide based on their findings. Ade et al. (2010) examined the effects of realistic environmental levels of imidacloprid $(9 \mathrm{mg} / \mathrm{L})$ and predation on cricket frogs (Acris crepitans) and green frogs (Lithobates clamitans) and observed a 77\% decrease in cricket frog survival probability.

Several studies have investigated potential sublethal effects of imidacloprid exposure on anurans. Feng et al. (2004) analyzed DNA damage via comet assays on black-spotted frogs (Pelophylax nigromaculatus) and documented the lowest observable effect level (LOEL) at 0.05 mg/l and 8mg/l of imidacloprid in micronuclei testing. Ruiz de Arcaute (2014) found that cellular damage occurred in Montevideo tree frogs after 48 hours of exposure to $15 \mathrm{mg} / \mathrm{l}$ of imidacloprid. Egg masses from western chorus frogs (Pseudacris triseriata) that were exposed to 88-110 mg/l of imidacloprid resulted in deformities for $24 \%$ of tadpoles (Julian 2000). Van Meter (2014) studied the dermal uptake of imidacloprid in anuran tissue samples and discovered whole body imidacloprid presence in exposed individuals. In Van Meter (2015), barking treefrogs (Hyla gratiosa) exposed to direct spray application had significantly higher dermal uptake compared with individuals with indirect exposure to imidacloprid via soil contact.

Some studies have found no or positive effects of amphibian exposure to imidacloprid. A study involving larval wood frogs (Lithobates sylvaticus) exposed to $10 \mu \mathrm{g} / \mathrm{L}$ and $100 \mu \mathrm{g} / \mathrm{L}$ demonstrated increased survival rates compared to control individuals, but delayed metamorphosis (Robinson et al. 2017). Hrynyk et al. (2018) subjected laboratory premetamorphic African clawed frogs (Xenopus laevis) to two concentrations of imidacloprid (1 
$\mu \mathrm{g} / \mathrm{L}$ and $500 \mu \mathrm{g} / \mathrm{L}$ ) before infecting the individuals with Ranavirus strain FV3 to examine the effects of imidacloprid on infection susceptibility. They found exposure to imidacloprid reduced the mortality rates for exposed individuals relative to control individuals.

In the last few years, several studies have investigated imidacloprid impacts on salamanders. Danis and Marlatt (2021) found that northwestern salamander (Ambystoma gracile) larvae exposed to 750 and $2250 \mu \mathrm{g} / \mathrm{L}$ imidacloprid for 96 hours had a significant decrease in thyroid function but found no overall effect on larvae survival or mean body size. They also found that larvae exposed to $100 \mu \mathrm{g} / \mathrm{L}$ imidacloprid for 35 days had a significant increase in the rate of development of the right forelimb. In another laboratory study, Crayton (2019) documented a reduction in body condition and food intake in spotted salamanders (Ambystoma maculatum) that were housed in tanks with soil treated with imidacloprid. Using ultraperformance liquid chromatography-tandem mass spectrometry ([UP] LC-MS/MS), they found that individuals exposed to imidacloprid in the experiment had detectable levels of imidacloprid and two common imidacloprid metabolites (imidacloprid olefin and imidacloprid urea). In a field study, Crayton et al. (2020) found that Desmognathus salamanders in streams adjacent to HWA treatment areas had significantly increased stress hormone levels and decreased body condition index scores associated with higher stream imidacloprid concentrations. They also discovered imidacloprid bioaccumulation in whole salamander body tissue samples from 31 D. monticola and 16 D. fuscus. In Great Smoky Mountains National Park, Cox (2020) found higher relative abundances of three salamander species (Eurycea wilderae, Plethodon jordani, Desmognathus wrighti) in designated hemlock conservation areas that had received imidacloprid treatments compared to unmanaged sites in late-stage HWA infestation. 


\section{IMIDACLOPRID AND ANTS}

Soils are critical habitat for a wide range of organisms, such as macro- and mesoinvertebrates, microbes, prokaryotes, and various subterranean vertebrates (Coleman and Whitman 2005, Fitter et al. 2005). Carbon, nitrogen, and phosphorous levels in the soil are heavily influenced by soil-dwelling organism activity, and the effects of those activities can be seen at the ecosystem level (Fitter et al. 2005). Ants are primary food source for many taxa, including birds, mammals, reptiles and amphibians (reviewed in Bequaert 1922). They are often primary prey items for woodland salamanders, comprising up to 33\% of their diet (Burton 1976, Pauley 1978, Ivanov et al. 2011). Ants are an important ecological foundation taxon in both agricultural and ecological settings and are referred to as "ecosystem engineers" (Holldobler and Wilson 1990) because of their ability to impact physio-chemical properties of their surrounding environments. Their impacts start in the soil, altering micro-organism communities, other macroinvertebrate species richness and diversity, and plant communities (reviewed in Folgarait 1998). In agricultural settings, ants are used as biological control agents to combat fungal pathogens and crop insect pests (reviewed in Philpott and Armbrecht 2006), while simultaneously controlled as a pest in many other agricultural applications.

Like other insects, imidacloprid-induced ant mortality can occur relatively quickly. However, in a pest control setting, delayed toxicity to allow for trail following by other colony members is necessary for whole colony pest control. Concentrations that are too high can kill worker ants too quickly, blocking the delivery of the bait to the larvae housed inside the physical colony structure (Rust et al. 2004). This mode of toxicity could lend itself to non-target colony mortality in low imidacloprid concentrations that may be found in treated hemlock plots. 
The lowest published concentration of imidacloprid that was linked to observable sublethal effects in ants (Pogonomyrmex occidentalis; Hymenoptera: Formicidae) was 50 ppb $(0.05 \mu \mathrm{g} / \mathrm{g})$. Ants exposed to this concentration required four to six times longer than control ants to locate food, though nest-building ability was not impaired (Sappington 2018). Wang et al. (2015) discovered that $0.25 \mu \mathrm{g} / \mathrm{ml}$ imidacloprid decreased Solenopsis invicta (Hymenoptera: Formicidae) queens brood tending ability, extended larval emergence time, and stopped production of pupae and adult workers. Grooming behavior was inhibited in leaf-cutting ants (Acromyrmex s. subterraneus; Hymenoptera: Formicidae) by imidacloprid, which is a primary defense against colony-wide fungal infections (Galvanho et al. 2013). Defensive behaviors can also be affected when individuals are exposed to sublethal doses of imidacloprid, causing some species to lower aggression and others to increase aggression (Barbieri et al. 2013).

\section{STUDY AREA}

This study was conducted on two of the NPS units in southern West Virginia, NERI and GARI. NERI was established in 1978 and is the larger of the two parks at approximately 29,137 ha (National Park Service 2020). GARI was established in 1988 and contains approximately 4,654 ha. Elevation in the two units ranges from approximately $244 \mathrm{~m}$ at river level near Gauley Bridge to approximately $853 \mathrm{~m}$ above Slater Creek near the town of Thayer (data accessed via Topoview; https://ngmdb.usgs.gov/topoview). Both units are characterized as steep-sloped river

gorges and are located in the Valley and Ridge province of the Appalachian Mountains (National Park Service 2016). The Köppen-Geiger Climate Classification of this region is Cfc (warm temperate, fully humid, and cool summer; (Kottek et al. 2006). This area of West Virginia 
receives an average of $104 \mathrm{~cm}$ of rain per year, with an annual average temperature of $11^{\circ} \mathrm{C}$ (National Oceanic and Atmospheric Administration 2016).

Specific study sites were placed within eastern hemlock forests that were either previously treated or never treated with imidacloprid. Treatment history and intensity varied among study sites. The Fern Creek area (Fern Creek 1, 2, and 4) received treatments at least once

per year over a span of twelve years (2006-2018), while areas such as Nuttall, Poll's Branch, and Fern Buttress only received one treatment in one year (mean for all areas $=3.75$ treatments per year; Table 1-1). The number of total treated trees per treatment area ranged from 17 trees (Nuttall) to 4,004 trees (Fern Creek) with treatment acres per area per year differing substantially (Bridge Buttress $=0.20$ ha in 2013; Fern Creek $=36.5$ ha in 2010; mean $=5.7$ ha; Table 1-1). The number of years between the start of salamander sampling and the last year of treatments ranged from 0 years (Fern Creek) to 5 years (Bridge Buttress and Nuttall), with a mean of 1.9 years for all areas. Each treatment plot had a matched control plot that had similar environmental characteristics, and the pairs were established in close geographical proximity (mean $=385 \mathrm{~m}$, range $=40-852 \mathrm{~m})$.

\section{RESEARCH NEED}

At NERI and GARI, imidacloprid is primarily applied to the soil at the base of trees. While many non-target species can be exposed to imidacloprid, ground-dwelling species with low vagility likely have comparatively high exposure levels. Woodland salamanders (Plethodon spp.) and ants (Formicidae) are low vagility taxa that are strongly tied to the soil environment (Welsh and Droege 2001). Woodland salamanders and ants live and feed in the soil, and their eggs are laid and develop in the soil (Holldobler and Wilson 1990). Further, woodland salamander respiration 
takes place through their permeable dermal layer, making them particularly sensitive to environmental contamination (Quaranta et al. 2009). Thus, woodland salamanders and ants are useful sentinel species for understanding potential non-target impacts of imidacloprid on forest animal communities.

Imidacloprid exposure through direct contact or consumption of contaminated prey could result in lethal or sublethal effects to salamanders. Potential sublethal impacts on salamanders include behavioral changes, impaired growth and reproduction (either through direct exposure or indirectly through reduced prey availability), induced immunosuppression, and damaged DNA (Julian 2000, Feng et al. 2004, Ade et al. 2010, Bayci 2011, Mason et al. 2014, Pérez-Iglesias et al. 2014, Ruiz de Arcaute et al. 2014). There are seven protected salamander species in NERI: Midland mud salamander (Pseudotriton montanus diastictus; S1 [critically imperiled]), Jefferson salamander (S2 [rare and imperiled]), Cumberland Plateau salamander (Plethodon kentucki; S2), green salamander (Aneides aeneus; S3 [vulnerable to extirpation]), black-bellied salamander (Desmognathus quadramaculatus; S3), cave salamander (Eurycea lucifuga; S3), and northern red salamander (Pseudotriton ruber; S3).

A decrease in ant community composition could result in altered soil chemical properties, decomposition rates, and nutrient cycling (Wardle et al. 2011, Del Toro et al. 2012, Kendrick et al. 2015). Ants are a primary prey source for many woodland salamanders (Petranka 2010, Lewis et al. 2014, Paluh et al. 2015). Thus, a decline in ant abundance could impact the woodland salamander community, potentially increasing competition for food sources and ultimately reducing environmental carrying capacity for salamanders (Thurow 1976, Mathis 1990). Additionally, ants present a potential route of imidacloprid bioaccumulation in salamanders via dietary exposure (Rabitsch 1997, Peijnenburg et al. 2012). 


\section{RESEARCH OBJECTIVES}

The objectives of this thesis are to determine if a real-world imidacloprid application program for hemlock preservation is influencing abundance, diversity, and health of woodland salamanders and ants. In Chapter 2, we investigated whether exposure to imidacloprid treatments affected the relative abundance and health (i.e., body condition) of woodland salamanders. In Chapter 3, we investigated the effects of imidacloprid treatments on ant species relative abundance and diversity. The results of this research project may be used to assist NPS management in assessing best practices for the long-term management of HWA-infested hemlock forests.

\section{Literature Cited}

Ade, C. M., M. D. Boone, and H. J. Puglis. 2010. Effects of an insecticide and potential predators on green frogs and northern cricket frogs. Journal of Herpetology 44:591-600.

Barbieri, R. F., P. J. Lester, A. S. Miller, and K. G. Ryan. 2013. A neurotoxic pesticide changes the outcome of aggressive interactions between native and invasive ants. Proceedings of the Royal Society B: Biological Sciences 280:20132157.

Bayci, M. N. 2011. Effects of a neonicotinoid insecticide on larval stages of the green frog, Rana clamitans. Thesis, Kalamazoo College, Kalamazoo, USA.

Bequaert, J. 1922. The predaceous enemies of ants. Pages 271-331 in. Bulletin of the American Museum of Natural History. Volume 45. New York, New York, USA.

Brisbin, R. L. 1970. Eastern Hemlock (Tsuga canadensis (L.) Carr.). U.S. Department of Agriculture - American Woods FS-239:1-8.

Buck, L., P. Lambdin, D. Paulsen, J. Grant, and A. Saxton. 2005. Insect species associated with eastern hemlock in the Great Smoky Mountains National Park and Environs. Journal of the Tennessee Academy of Science 80:60-69.

Burton, T. M. 1976. An analysis of the feeding ecology of the salamanders (Amphibia, Urodela) of the Hubbard Brook Experimental Forest, New Hampshire. Journal of Herpetology 10:187-204.

Cheah, C., M. E. Montgomery, R. C. Reardon, and B. Onken. 2004. Biological control of hemlock woolly adelgid. USDA Forest Service, Forest Health Technology Enterprise Team, Morgantown, WV, USA.

Coleman, D. C., and W. B. Whitman. 2005. Linking species richness, biodiversity and ecosystem function in soil systems. Pedobiologia 49:479-497. 
Cowles, R. S., C. S.-J. Cheah, and M. E. Montgomery. 2005. Comparing systemic imidacloprid application methods for controlling hemlock woolly adelgid. Pages 169-172 in Proceedings, 16th U.S. Department of Agriculture interagency research forum on gypsy moth and other invasive species. USDA Forest Service, Hamden, Connecticut, USA.

Cowles, R. S., M. E. Montgomery, and C. S.-J. Cheah. 2006. Activity and residues of imidacloprid applied to soil and tree trunks to control hemlock woolly adelgid (Hemiptera: Adelgidae) in forests. Journal of Economic Entomology 99:1258-1267.

Cox, J. L. 2020. Conservation of terrestrial salamanders through hemlock woolly adelgid management in eastern hemlock forests within Great Smoky Mountains National Park. Thesis. University of Tennessee, Knoxville, Tennessee, USA.

Crayton, S. M. 2019. Stream salamander and benthic macroinvertebrate community responses to imidacloprid exposure. Thesis, West Virginia University, Morgantown, West Virginia, USA.

Crayton, S. M., P. B. Wood, D. J. Brown, A. R. Millikin, T. J. McManus, T. J. Simpson, K-M. $\mathrm{Ku}$, and Y-L. Park. 2020. Bioaccumulation of the pesticide imidacloprid in stream organisms and sublethal effects on salamander. Global Ecology and Conservation 24:e01292.

Danis, B. E. G., and V. L. Marlatt. 2021. Investigating acute and subchronic effects of neonicotinoids on northwestern salamander larvae. Archives of Environmental Contamination and Toxicology 80:691-707.

Del Toro, I., R. R. Ribbons, and S. L. Pelini. 2012. The little things that run the world revisited: a review of ant-mediated ecosystem services and disservices (Hymenoptera: Formicidae). Myrmecological News 17:133-146.

Dilling, C., P. Lambdin, J. Grant, and L. Buck. 2007. Insect guild structure associated with eastern hemlock in the southern Appalachians. Environmental entomology 36:1408-1414.

Dilling, C., P. Lambdin, J. Grant, and R. Rhea. 2010. Spatial and temporal distribution of imidacloprid in eastern hemlock in the southern Appalachians. Journal of Economic Entomology 103:368-373.

Eisenback, B. M., D. E. Mullins, S. M. Salom, and L. T. Kok. 2009. Evaluation of ELISA for imidacloprid detection in eastern hemlock (Tsuga canadensis) wood and needle tissues. Pest Management Science 65:122-128.

Evans, A. M., and T. G. Gregoire. 2007. A geographically variable model of hemlock woolly adelgid spread. Biological Invasions 9:369-382.

Evans, R. A. 2002. An ecosystem unraveling. Pages 23-33 in Proceedings of the Hemlock Woolly Adelgid in Eastern North America Symposium. USDA Forest Service, East Brunswick, New Jersey, USA.

Farjon, A. 1990. Pinaceae. Drawings and descriptions of the genera Abies, Cedrus, Pseudolarix, Keteleeria, Nothotsuga, Tsuga, Cathaya, Pseudotsuga, Larix and Picea. Koeltz Scientific Books. Lubrecht and Cramer Ltd, Konigstein, Germany.

Feng, S., Z. Kong, X. Wang, L. Zhao, and P. Peng. 2004. Acute toxicity and genotoxicity of two novel pesticides on amphibian, Rana $n$. hallowell. Chemosphere 56:457-463.

Finzi, A. C., N. Van Breemen, and C. D. Canham. 1998. Canopy tree-soil interactions within temperate forests: species effects on soil carbon and nitrogen. Ecological Applications $8: 440-446$. 
Fitter, A. H., C. A. Gilligan, K. Hollingworth, A. Kleczkowski, R. M. Twyman, and J. W. Pitchford. 2005. Biodiversity and ecosystem function in soil. Functional Ecology 19:369_ 377.

Folgarait, P. J. 1998. Ant biodiversity and its relationship to ecosystem functioning: a review. Biodiversity and Conservation 7:1221-1244.

Fossen, M. 2006. Environmental fate of imidacloprid. California Department of Pesticide Regulation, Sacramento, California, USA.

Galvanho, J. P., M. P. Carrera, D. D. O. Moreira, M. Erthal, C. P. Silva, and R. I. Samuels. 2013. Imidacloprid inhibits behavioral defences of the leaf-cutting ant Acromyrmex subterraneus subterraneus (Hymenoptera: Formicidae). Journal of Insect Behavior 26:1-13.

Gouger, R. J. 1971. Control of Adelges tsugae on hemlock in Pennsylvania. Scientific Tree Topics 3:6-9.

Havill, N. P., L. C. Vieira, and S. M. Salom. 2016. Biology and control of hemlock woolly adelgid. USDA Forest Service. Forest Health Technology Enterprise Team, Morgantown, West Virginia, USA.

Holldobler, B., and E. O. Wilson. 1990. The Ants. Belknap Press, Cambridge, Massachusetts, USA.

Hrynyk, M. A., C. Brunetti, L. Kerr, and C. D. Metcalfe. 2018. Effect of imidacloprid on the survival of Xenopus tadpoles challenged with wild type frog virus 3. Aquatic Toxicology 194:152-158.

Ivanov, K., O. M. Lockhart, J. Keiper, and B. M. Walton. 2011. Status of the exotic ant Nylanderia flavipes (Hymenoptera: Formicidae) in northeastern Ohio. Biological Invasions 13:1945-1950.

Jenkins, J. C., J. D. Aber, and C. D. Canham. 1999. Hemlock woolly adelgid impacts on community structure and $\mathrm{N}$ cycling rates in eastern hemlock forests. Canadian Journal of Forest Research 29:630-645.

Jeschke, P., and R. Nauen. 2008. Neonicotinoids - from zero to hero in insecticide chemistry. Pest Management Science 63:1084-1098.

Julian, S. E. 2000. Effects of chronic pesticide exposure on larval amphibians. Thesis, Frostburg State University, Frostburg, Maryland, USA.

Kantola, T., P. Lyytikäinen-Saarenmaa, R. N. Coulson, S. Strauch, M. D. Tchakerian, M. Holopainen, H. Saarenmaa, and D. A. Streett. 2014. Spatial distribution of hemlock woolly adelgid induced hemlock mortality in the southern Appalachians. Open Journal of Forestry 4:492-506.

Kendrick, J. A., R. R. Ribbons, A. T. Classen, and A. M. Ellison. 2015. Changes in canopy structure and ant assemblages affect soil ecosystem variables as a foundation species declines. Ecosphere 6:Article 77.

Kottek, M., J. Grieser, C. Beck, B. Rudolf, and F. Rubel. 2006. World Map of the KoppenGeiger Climate Classification Updated. Meteorologische Zeitschrif 15:259-263.

Lewis, J. D., G. M. Connette, M. A. Deyrup, J. E. Carrel, and R. D. Semlitsch. 2014. Relationship between diet and microhabitat use of red-legged salamanders (Plethodon shermani) in southwestern North Carolina. Copeia 2:201-205.

Liu, W., W. Zheng, Y. Ma, and K. Liu. 2006. Sorption and degradation of imidacloprid in soil and water. Journal of Environmental Science and Health Part B 41:623-634. 
Mason, R., H. Tennekes, F. Sánchez-bayo, and P. U. Jepsen. 2014. Immune suppression by neonicotinoid insecticides at the root of global wildlife declines. Journal of Environmental Immunology and Toxicology 1:3-12.

Mathis, A. 1990. Territoriality in a terrestrial salamander: The influence of resource quality and body size. Behavior 112:162-175.

McClure, M. S. 1991. Density-dependent feedback and population cycles in Adelges tsugae (Homoptera: Adelgidae) on Tsuga canadensis. Environmental Entomology 20:258-264.

McClure, M. S. 1996. Biology of Adelges tsugae and its potential for spread in the northeastern United States. Pages 16-25 in Proceedings of the First Hemlock Woolly Adelgid Review. Charlottesville, Virginia, USA.

Mladenoff, D. J. 1987. Dynamics of nitrogen mineralization and nitrification in hemlock and hardwood treefall gaps. Ecology 68:1171-1180.

Mullins, J. W. 1993. Imidacloprid: a new nitroguanidine insecticide. Pages 184-198 in S. O. Duke, J. J. Menn, and J. R. Plimmer, editors. Pest Control with Enhanced Environmental Safety. American Chemical Society, Washington, D.C., USA.

National Oceanic and Atmospheric Administration. 2016. Summary of Monthly Normals. <http://www.ncdc.noaa.gov/cdo-web/datatools/normals>. Accessed 6 Nov 2019.

National Park Service. 2016. Foundation Document: New River Gorge National River. National Park Service, Glen Jean, West Virginia, USA.

National Park Service. 2020. New River Gorge National River home page. <https://www.nps.gov/neri/index.htm>. Accessed 6 Nov 2019.

Natural Resources Conservation Service. 2020. The PLANTS Database (http://plants.usda.gov, 1 July 2020). National Plant Data Team, Greensboro, North Carolina, USA.

Onken, B., and R. Reardon. 2008. Fourth symposium on hemlock woolly adelgid in the eastern United States. USDA Forest Service, Forest Health Technology Enterprise Team, Hartford, Connecticut, USA.

Orwig, D. A., and D. R. Foster. 2000. Stand, landscape, and ecosystem analyses of hemlock woolly adelgid outbreaks in southern New England: an overview. Proceedings on the symposium on sustainable management of hemlock ecosystems in eastern North America 267:123-125.

Paluh, D. J., C. Eddy, K. Ivanov, C.-A. M. Hickerson, and C. D. Anthony. 2015. Selective foraging on ants by a terrestrial polymorphic salamander. American Midland Naturalist 174:265-277.

Pauley, T. K. 1978. Food types and distribution as a Plethodon habitat partitioning factor. Bulletin of the Maryland Herpetological Society 14:79-82.

Peijnenburg, W., E. Capri, C. Kula, M. Liess, R. Luttik, M. Montforts, P. Sousa, K. Nienstedt, J. Rombke, J. P. Sousa, and J. Jensen. 2012. Evaluation of exposure metrics for effect assessment of soil invertebrates. Critical Reviews in Environmental Science and Technology 42:1862-1893.

Pérez-Iglesias, J. M., C. Ruiz de Arcaute, N. Nikoloff, L. Dury, S. Soloneski, G. S. Natale, and M. L. Larramendy. 2014. The genotoxic effects of the imidacloprid-based insecticide formulation Glacoxan Imida on Montevideo tree frog Hypsiboas pulchellus tadpoles (Anura, Hylidae). Ecotoxicology and Environmental Safety 104:120-126.

Petranka, J. W. 2010. Salamanders of the United States and Canada. Smithsonian Books, Washington D.C., USA. 
Philpott, S. M., and I. Armbrecht. 2006. Biodiversity in tropical agroforests and the ecological role of ants and ant diversity in predatory function. Ecological Entomology 31:369-377.

Quaranta, A., V. Bellantuono, G. Cassano, and C. Lippe. 2009. Why amphibians are more sensitive than mammals to xenobiotics. PLoS ONE 4:e7699.

Rabitsch, W. B. 1997. Tissue-specific accumulation patterns of $\mathrm{Pb}, \mathrm{Cd}, \mathrm{Cu}, \mathrm{Zn}, \mathrm{Fe}$, and $\mathrm{Mn}$ in workers of three ant species (Formicidae, Hymenoptera) from a metal-polluted site. Archives of Environmental Contamination and Toxicology 32:172-177.

Robinson, S. A., S. D. Richardson, R. L. Dalton, F. Maisonneuve, V. L. Trudeau, B. D. Pauli, and S. S. Y. Lee-Jenkins. 2017. Sublethal effects on wood frogs chronically exposed to environmentally relevant concentrations of two neonicotinioid insecticides. Environmental Toxicology and Chemistry 36:1101-1109.

Rosenthal, J., and R. Wildova. 2017. Relating eastern hemlock (Tsuga canadensis) ecosystem services to stand attributes in the Catskills. Ecological Research Institute, Kingston, New York, USA.

Ruiz de Arcaute, C., J. M. Pérez-Iglesias, N. Nikoloff, G. S. Natale, S. Soloneski, and M. L. Larramendy. 2014. Genotoxicity evaluation of the insecticide imidacloprid on circulating blood cells of Montevideo tree frog Hypsiboas pulchellus tadpoles (Anura, Hylidae) by comet and micronucleus bioassays. Ecological Indicators 45:632-639.

Rust, A., K. Michael, A. Donald, H. John, and J. H. Klotz. 2004. Delayed toxicity as a critical factor in the efficacy of aqueous baits for controlling argentine ants (Hymenoptera: Formicidae). Journal of Economic Entomology 97:1017-1024.

Sappington, J. D. 2018. Imidacloprid alters ant sociobehavioral traits at environmentally relevant concentrations. Ecotoxicology 27:1179-1187.

Sarkar, M., S. Roy, R. Kole, and A. Chowdhury. 2001. Persistence and metabolism of imidacloprid in different soils of West Bengal. Pest Management Science 57:598-602.

Sasaji, H., and M. S. McClure. 1997. Description and distribution of Pseudoscymnus tsugae sp. nov. (Coleoptera: Coccinellidae), an important predator of hemlock woolly adelgid in Japan. Annals of the Entomological Society of America 90:563-568.

Schroeder, M. E., and R. F. Flattum. 1984. The mode of action and neurotoxic properties of the nitromethylene heterocycle insecticides. Pesticide Biochemistry and Physiology 22:148160.

Siderhurst, L. A., H. P. Griscom, M. Hudy, and Z. J. Bortolot. 2010. Changes in light levels and stream temperatures with loss of eastern hemlock (Tsuga canadensis) at a southern Appalachian stream: implications for brook trout. Forest Ecology and Management 260:1677-1688.

Silcox, C. A. 2002. Using imidacloprid to control hemlock woolly adelgid. Pages 280-287 in Proceedings in hemlock woolly adelgid in the eastern United States. USDA Forest Service, East Brunswick, New Jersey, USA.

Smith, S. F., and V. A. Krischik. 1999. Effects of systemic imidacloprid on Coleomegilla maculata (Coleoptera: Coccinellidae). Environmental Entomology 28:1189-1195.

Souto, D., T. Luther, and R. Chianese. 1995. Past and current status of hemlock woolly adelgid in eastern and Carolina hemlock stands. Proceedings of the first hemlock woolly adelgid review. USDA Forest Service, Forest Health Technology Enterprise Team, Charlottesville, Virginia, USA. 
Strickler, L. K. 2012. Hemlock woolly adelgid control project annual report 2012: New River Gorge National River, Gauley River National Recreation Area, and Bluestone National Scenic River. National Park Service, New River Gorge National River, Glen Jean, West Virginia, USA.

Tattar, T. A., J. A. Dotson, and M. S. Ruizzo. 1998. Translocation of imidacloprid in three tree species. Journal of Arboriculture 24:54-56.

Taylor, R. J. 1972. The relationship and origin of Tsuga heterophylla and Tsuga mertensiana based on phytochemical and morphological interpretations. American Journal of Botany 59:149-157.

Thurow, G. 1976. Aggression and competition in eastern Plethodon (Amphibia, Urodela, Plethodontidae). Journal of Herpetology 10:277-291.

Turcotte, R. M., A. Lagalante, J. Jones, F. Cook, T. Elliott, A. A. Billings, and Y. L. Park. 2017. Spatial and temporal distribution of imidacloprid within the crown of eastern hemlock. Journal of Insect Science 17:1-7.

Van Meter, R. J., D. A. Glinski, W. M. Henderson, A. W. Garrison, M. Cyterski, and S. T. Purucker. 2015. Pesticide uptake across the amphibian dermis through soil and overspray exposures. Archives of Environmental Contamination and Toxicology 69:545-556.

Vanderhorst, J., J. Jeuck, and S. Gawler. 2007. Vegetation classification and mapping of New River Gorge National River, West Virginia. National Park Service Northeast Region, Philadelphia, Pennsylvania, USA.

Ward, J. S., M. E. Montgomery, C. A. Cheah, B. P. Onken, and R. S. Cowles. 2004. Eastern hemlock forests: guidelines to minimize the impacts of hemlock woolly adelgid. USDA Forest Service, Northeastern Area State and Private Forestry, Morgantown, WV, USA.

Wardle, D. A., F. Hyodo, R. D. Bardgett, G. W. Yeates, and M.-C. Nilsson. 2011. Long-term aboveground and belowground consequences of red wood ant exclusion in boreal forest. Ecology 92:645-656.

Welsh, H. H., Jr., and S. Droege. 2001. A case for using plethodontid salamanders for monitoring biodiversity and ecosystem integrity of North American forests. Conservation Biology 15:558-569.

Wood, J. M. 1999. Final report: hemlock ecosystem inventory and monitoring project of the New River Gorge National River and Gauley River National Recreation Area. U.S. Department of Interior, National Park Service, New River Gorge National River and Gauley River National.

Wood, P. B., J. H. Perez, and J. M. Wood. 2008. Hemlock ecosystem monitoring in southern West Virginia. Pages 270-278 in B. P. Onken and R. C. Reardon, editors. Proceedings of the Fourth Symposium on Hemlock Woolly Adelgid in the Eastern United States. USDA Forest Service, Forest Health Technology Enterprise Team, Hartford, Connecticut, USA.

Yorks, T. E., J. C. Jenkins, D. J. Leopold, D. J. Raynal, and D. A. Orwig. 1999. Influences of eastern hemlock mortality on nutrient cycling. Pages 126-133 in Proceedings in symposium on sustainable management of hemlock ecosystems in eastern North America. USDA Forest Service, Durham, New Hampshire, USA.

Young, R. F., K. S. Shields, and G. P. Berlyn. 1995. Hemlock woolly adelgid (Homoptera: Adelgidae): stylet bundle insertion and feeding sites. Annals of the Entomological Society of America 88:827-835. 


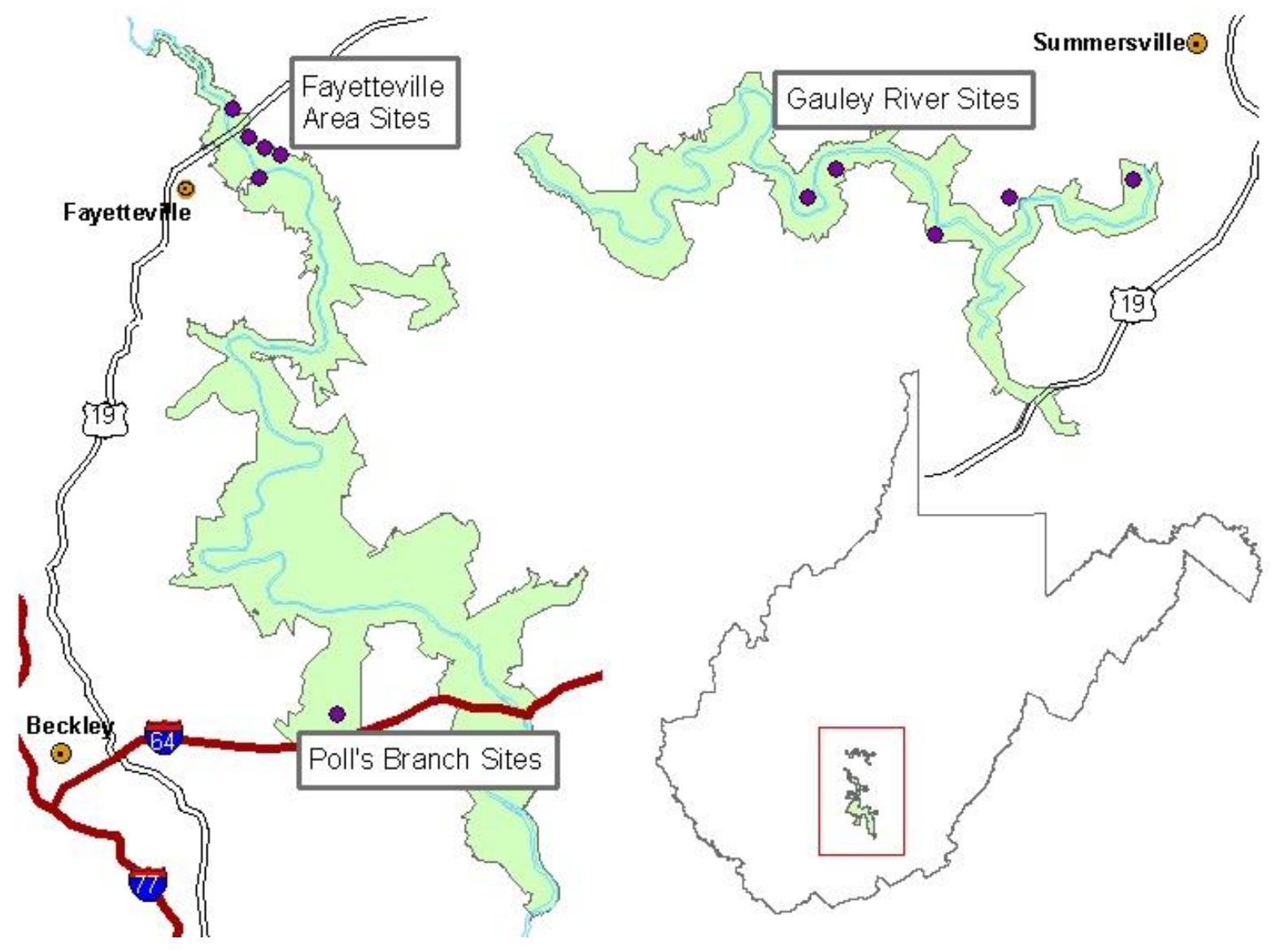

Figure 1-1. General locations of research plots in New River Gorge National River (NERI) and Gauley River National Recreation Area (GARI), West Virginia, USA. The Fayetteville area has 10 research sites (Bridge Buttress, Burnwood 1, Burnwood 2, Fern Buttress, Fern Creek 1, Fern Creek 2, Fern Creek 4, Kaymoor 1, Kaymoor 2, and Nuttall sites). In southern NERI, Poll's Branch research area consists of 2 sites. The remaining 8 research sites are in GARI (upper right) and consists of Carnifex Ferry, Elliott Cutoff, Richmond Chapel, Summersville Dam 1, Summersville Dam 2, Wood's Ferry. Each site consists of a control and a treatment plot, for a total of 36 plots. 
Table 1-1. Imidacloprid treatment details for the history of eastern hemlock (Tsuga canadensis) conservation efforts in Gauley River National Recreation Area and New River Gorge National River in West Virginia, USA. Imidacloprid was applied as a soil drench, soil tablet, or a trunk injection to protect the trees from the impacts of hemlock woolly adelgid (Adelges tsugae).

\begin{tabular}{|c|c|c|}
\hline Site Name & Treatment Years & Number of Treated Trees \\
\hline \multirow{2}{*}{ Bridge Buttress } & 2009 & 101 \\
\hline & 2013 & 8 \\
\hline \multirow{7}{*}{ Burnwood } & 2009 & 252 \\
\hline & 2010 & 139 \\
\hline & 2011 & 29 \\
\hline & 2012 & 107 \\
\hline & 2013 & 50 \\
\hline & 2014 & 179 \\
\hline & 2015 & 128 \\
\hline \multirow{3}{*}{ Carnifex Ferry } & 2014 & 88 \\
\hline & 2016 & 91 \\
\hline & 2017 & 35 \\
\hline \multirow{3}{*}{ Elliott Cutoff } & 2014 & 179 \\
\hline & 2015 & 142 \\
\hline & 2016 & 173 \\
\hline Fern Buttress & 2016 & 76 \\
\hline \multirow{12}{*}{ Fern Creek } & 2006 & 290 \\
\hline & 2007 & 596 \\
\hline & 2008 & 814 \\
\hline & 2009 & 451 \\
\hline & 2010 & 469 \\
\hline & 2011 & 264 \\
\hline & 2012 & 633 \\
\hline & 2013 & 296 \\
\hline & 2014 & 1 \\
\hline & 2015 & 108 \\
\hline & 2016 & 22 \\
\hline & 2017 & 60 \\
\hline \multirow{5}{*}{ Kaymoor } & 2007 & 111 \\
\hline & 2010 & 87 \\
\hline & 2012 & 64 \\
\hline & 2015 & 20 \\
\hline & 2016 & 18 \\
\hline Nuttall & 2013 & 17 \\
\hline Poll's Branch & 2016 & 470 \\
\hline \multirow{3}{*}{ Richmond Chapel } & 2014 & 513 \\
\hline & 2015 & 389 \\
\hline & 2016 & 224 \\
\hline \multirow{2}{*}{ Summersville Dam } & 2014 & 289 \\
\hline & 2015 & 79 \\
\hline \multirow{5}{*}{ Wood's Ferry } & 2010 & 23 \\
\hline & 2011 & 7 \\
\hline & 2014 & 426 \\
\hline & 2015 & 428 \\
\hline & 2016 & 362 \\
\hline
\end{tabular}




\section{CHAPTER 2: EFFECTS OF IMIDACLOPRID EXPOSURE ON WOODLAND SALAMANDER RELATIVE ABUNDANCE AND HEALTH}

\section{ABSTRACT}

Eastern hemlocks (Tsuga canadensis) are being threatened by hemlock woolly adelgid (HWA; Adelges tsugae), an invasive insect from Japan. One method used by forest managers to protect eastern hemlocks from the impacts of HWA infestation is imidacloprid. Imidacloprid is a systemic, neonicotinoid insecticide that has been shown to impact non-target organisms, including amphibians. We assessed the effects of imidacloprid treatments for HWA on woodland salamander relative abundance and health in eastern hemlock forests in two National Park Service (NPS) units in southern West Virginia, USA. We surveyed woodland salamanders (genus Plethodon) 12-17 times over 2.5 years at 18 control sites paired with 18 treatment sites. Treatment plots had received imidacloprid treatments at least one time since 2006. We used linear mixed-effects and regression models, coupled with a model selection approach, to identify important environmental predictors of woodland salamander relative abundance (measured as captures-per-unit-effort) and body condition, and used the most parsimonious models to test the influence of three imidacloprid predictors: treatment presence, total treated tree diameter at breast height (DBH; a proxy for treatment intensity), and years since treatment (YST). We did not find evidence for an overall difference in relative abundance between control and treatment plots. Body condition index score of adult salamanders was negatively associated with treated tree DBH and positively associated with YST at treatment sites, with a stronger YST relationship at sites with greater treated tree DBH. In addition, 8 eastern red-backed salamanders (Plethodon 
cinereus) collected from treatment areas contained imidacloprid, indicating terrestrial salamanders are uptaking the pesticide.

\section{INTRODUCTION}

Eastern hemlock (Tsuga canadensis) forests in the Appalachian Mountains generate unique microclimates that provide important habitat for a wide assemblage of aquatic and terrestrial plants, insects, and wildlife (Yamasaki et al. 1999, Ellison et al. 2005, Dilling et al. 2007, Mathewson 2009, Orwig et al. 2013). The dense canopy in a hemlock-dominated forest can prevent up to $99 \%$ of sunlight from reaching the forest floor (Hadley 2000), resulting in lower soil and stream temperatures than deciduous forests (Mladenoff 1987, Hadley 2000, Ross et al. 2003). High amounts of tannin in hemlock leaf litter contribute to lower rates of decomposition and nutrient cycling, and lower soil pH levels (White 1986, Mladenoff 1987, Elliott et al. 1993, Finzi et al. 1998). Eastern hemlock forests are being decimated by hemlock woolly adelgid (HWA), an exotic, nonnative, aphid-like insect that was first recorded in the U.S. on specimens collected in Richmond, VA in 1951 (Havill et al. 2014). Hemlock woolly adelgid likely arrived earlier in the $20^{\text {th }}$ century via nursery trees shipped from Asia (Gouger 1971, Orwig and Foster 2000, Cheah et al. 2004, Buck et al. 2005). By 2014, HWA was estimated to have spread to ca. $50 \%$ of the range of eastern hemlocks (Havill et al. 2014). In response to HWA infestation and spread, chemical treatments using the insecticide imidacloprid are applied systemically in the

trunk, sprayed on foliage, and applied to the soil at the base of the tree to protect the trees from HWA induced mortality (Cowles et al. 2006).

Woodland salamanders (genus Plethodon) are an important component of forest ecosystems in the eastern United States (Burton and Likens 1975a, b, Welsh and Droege 2001, 
Mathewson 2009, Best and Welsh 2014) and can reach high densities in optimal habitat conditions (Burton and Likens 1975a, Wyman 1998). As mid-trophic level organisms, woodland salamanders can exert a large influence on trophic dynamics (Best and Welsh 2014). Using experimental enclosures, Wyman (1998) found that presence of $P$. cinereus resulted in significantly lower arthropod abundances, which lowered litter decomposition rates. Burton and Likens (1975b) estimated that salamander populations comprise approximately $20 \%$ of energy (kcal) moving through avian and mammalian populations.

Woodland salamanders are ideal taxa for forest ecotoxicological monitoring due to their ecological importance as well as their biology. As lungless salamanders, gas and moisture exchange occur through a thin dermal layer, and uptake of environmental toxins can occur through dermal exposure (Quaranta et al. 2009). Additionally, their permeable, non-amniotic eggs are laid in the soil, with embryonic development influenced by external soil characteristics (Petranka 2010, Boone 2018). Woodland salamanders are also long-lived (i.e., maximum life span up to 16 years; Marvin 2001), have small home ranges and high site fidelity (Mathis 1990, Marvin 2001, Ousterhout and Liebgold 2010), and have low vagility (Wells and Wells 1976). These life history characteristics indicate that individual salamanders could have years of continuous exposure to environmental contaminants such as pesticides. In addition to exposure via soil, amphibians can uptake pesticides through water (Brühl et al. 2011; Van Meter et al. 2014, 2015; Crayton 2019). Continuous exposure to environmental contaminants, including the pesticide imidacloprid, could also occur by ingesting contaminated prey. Nontarget arthropods can exhibit sublethal, neurotoxic effects such as delayed mobility and paralysis (Kunkel et al. 1999, 2001). The delay between exposure and mortality makes the exposed insects available for 
consumption by salamanders, but the prevalence of this mode of exposure for salamanders is unknown.

Direct effects of pesticide exposure can cause mortality to amphibians or exert sublethal effects such as immunosuppression, growth impairment, altered reproduction condition, behavioral changes, body condition, or genetic changes (reviewed in Brühl et al. 2011). Imidacloprid has been found to cause cellular-level damage in nucleated erythrocyte cells of amphibians (Feng et al. 2004, Pérez-Iglesias et al. 2014, Ruiz de Arcaute et al. 2014), and increase stress hormone levels (Crayton et al. 2020). Julian (2000) studied the impact of chronic low, medium, and high imidacloprid exposure on toxicity, larval development, and behavior of five amphibian species (Lithobates pipiens, Lithobates sphenocephalus, Anaxyrus americanus, Pseudacris triseriata, and Ambystoma jeffersonianum). Results showed a significant decrease in rates of survival to metamorphosis and a significant increase in days to metamorphosis for all three frog species at high imidacloprid concentrations. Significantly reduced growth rates were observed in L. sphenocephalus exposed to medium concentration levels of imidacloprid. A. jeffersonianum (the only salamander species in the study) hatchlings in low, medium, and high concentrations of imidacloprid had higher rates of deformities than control individuals, though hatching success was not impaired by imidacloprid exposure. In another laboratory study, Danis and Marlatt (2021) observed significantly increased growth rates of Ambystoma gracile larvae that had been exposed to $100 \mu \mathrm{g} / \mathrm{L}$ imidacloprid for 35 days, providing some evidence that field realistic concentrations of imidacloprid may affect thyroid function in exposed individuals.

Indirect effects of imidacloprid treatments to salamander populations center around the potential reduction in invertebrate prey abundance and diversity. Imidacloprid is the most widely used insecticide in the world (Silcox 2002, Jeschke et al. 2011), and there is expansive literature 
detailing the impacts of imidacloprid treatments on nontarget insect species in a range of habitat types (e.g., forests, agriculture, lawn and turf). Impacts have been documented in insect species associated with eastern hemlock forests that have been treated with imidacloprid (Reynolds 2008, Dilling et al. 2009, Uhl et al. 2015). Woodland salamanders prey almost entirely on arthropods, including insects (Green and Pauley 1987, Petranka 2010). Prey abundance for woodland salamanders may be reduced in treated eastern hemlock forests. Reduction in prey abundance and diversity could cause sublethal effects to woodland salamanders including decreased health, delayed development, and increased interspecific and intraspecific competition for food resources (Johnson and Wallace 2005, Becker and Harris 2010). Additionally, a decrease in certain insect guilds could lead to salamander habitat structure alteration caused by changes in litter decomposition rates, herbaceous vegetation growth, and soil chemical properties (Maerz et al. 2009, Kendrick et al. 2015).

The goal of this research project was to determine whether imidacloprid treatments in hemlock forests in NERI and GARI influenced salamander abundance and body condition. We hypothesized that relative abundances of juvenile and adult salamanders would be lower in areas with treated trees and would be negatively correlated with the amount of pesticide application in treated areas. Additionally, we hypothesized that body condition would be negatively affected by imidacloprid application.

\section{STUDY AREA}

We established 36 research plots in eastern hemlock forests in two NPS units in south-central West Virginia: New River Gorge National River (NERI) and Gauley River National Recreation Area (GARI; Figure 2-1). Both park units are located near the northern extent of the global 
salamander diversity hotspot in the Appalachian Mountains (Petranka 2010). A moderate annual average temperature $\left(30\right.$-year mean $\left.=11.1^{\circ} \mathrm{C}\right)$, high annual precipitation $(30$-year mean $=104.6$ $\mathrm{cm}$ ), and heterogenous topography create optimal habitat conditions for salamanders (Marshall and Camp 2006, National Oceanic and Atmospheric Administration 2016). Of the 24 species of salamanders confirmed in the New River Gorge region, 18 species are in the family Plethodontidae (Green and Pauley 1987), including 6 species of woodland salamanders (genus Plethodon).

At roughly 29,137 ha, approximately $5 \%$ (1,470 ha) of the total land in NERI is classified as eastern hemlock associated forest (Vanderhorst et al. 2007). Approximately 43\% (2,001 ha) of the 4,654 ha of GARI is classified as eastern hemlock associated forest (Vanderhorst et al. 2010). Between 2006 and 2017, hemlock forests in NERI were treated up to 12 times (mean $=4.1$ times, range $=1-12$ times), and had a total of 20,788 treated trees over all years (mean for all sites $=$ 118.8 trees, range $=4-4,004$ trees). Between 2009 and 2017, hemlock forests in GARI were treated up to 5 times (mean $=3.2$ times, range $=1-5$ times), and had a total of 3,448 trees treated across all years (mean for all sites $=689.6$ trees, range $=214-1,246$ trees).

We established 18 site pairs of control and treatment plots for sampling woodland salamander populations in NERI and GARI. We used a geographic information system (ArcGIS 10.4, ESRI, Redlands, California) to rank candidate sampling areas based on several factors, including treatment intensity (i.e., total number of treated trees), land ownership, proximity to trails (i.e., accessibility), and distance to sampling sites for concurrent aquatic salamander sampling (Crayton et al. 2020). Within selected areas, plot locations were established by first identifying eastern hemlock stands that had received imidacloprid treatments at least once between 2006 and 2016. Then, a paired control plot containing eastern hemlock and similar 
understory vegetation was established in the same geographical area as the treatment plot (at least $40 \mathrm{~m}$ away; mean distance $=385 \mathrm{~m}$, range $=40-852 \mathrm{~m}$ ). The relative position of the control plot to the treatment plot was also taken into consideration. Specifically, the control plot was not established downslope of the treatment plot due to the potential of imidacloprid to flow downslope with groundwater drainage patterns.

Sampling plots measured $20 \mathrm{~m}$ x $20 \mathrm{~m}$ and were divided into four $10 \mathrm{~m}$ x $10 \mathrm{~m}$ subplots (Figure 2-2). We sampled salamander populations using natural cover object and coverboard searches. In the center of each subplot, we established a coverboard grid consisting of six $15 \mathrm{~cm}$ x $30 \mathrm{~cm}$ boards cut from native hardwood species placed in two rows (Dodd 2003, Hesed 2012). Coverboard sites were cleared off the top layer of leaf litter and the boards were placed flush with the substrate. Coverboards were installed during the winter prior to the first year of salamander sampling. Natural cover objects (e.g., rocks, downed woody debris) $>15 \mathrm{~cm}$ in diameter were flagged prior to initiation of sampling and searched during each sampling event (Strojny and Hunter 2009). Additional natural cover objects that entered the plots after initiation of sampling were also searched.

\section{METHODS}

\section{Salamander Sampling}

We sampled nine of the site pairs in 2017 and 2019 and nine of the site pairs in 2018 and 2019. We sampled each plot $12-17$ times over the two years of sampling (mean $=14.3$ ), with a total of 516 surveys across all years and plots. We sampled in spring, summer, and fall (dates were the same as mentioned above) and attempted to complete roughly equal survey efforts among all sites for each sampling season. Each survey consisted of active searches of coverboards and 
natural cover objects for salamanders. The number of total objects turned was tallied for each survey to account for variation in cover object density among plots. In treatment plots, the distance to the nearest treated tree was recorded using a Bosch $15.2 \mathrm{~m}$ distance $( \pm 0.32 \mathrm{~cm})$ laser measurer. Salamanders were identified to species and measured (snout-vent length [SVL], tail length [TL]) to the nearest $0.1 \mathrm{~mm}$ using dial calipers, weighed to the nearest $0.1 \mathrm{~g}$ using a portable digital scale, sexed (when sexually dimorphic characteristics were present), and photographed. Processed salamanders were released in the same locations they were collected.

\section{Environmental Sampling}

Vegetation surveys. — In summer of 2018, vegetation surveys were conducted in all research plots. All trees $\geq 12.7 \mathrm{~cm}$ diameter at breast height $(\mathrm{DBH})$ rooted within the plots were identified to species, counted, measured, and identified as treated or untreated. This DBH size cut-off allowed us to include smaller coniferous and deciduous trees in our total plot DBH. We excluded the numerous clustering stems of great rhododendron (Rhododendron maximum), mountain laurel (Kalmia latifolia), and American holly (Ilex opaca) that were frequently $>12.7 \mathrm{~cm}$ in diameter in our plots.

Soil variables. - Soil related variables were sampled three times per plot, once during each salamander sampling season in 2018 (spring [March 20 - June 21], summer [June 22 September 22], fall [September 23 - December 22]). We measured soil variables as close to the middle of each season as possible to capture seasonal soil parameter norms. We measured mineral soil $\mathrm{pH}$ at the center of each subplot using an EcoSense $\mathrm{pH} 100 \mathrm{~A}$ meter with a piercing tip pH electrode (YSI, Yellow Springs, Ohio). A soil slurry was made by stirring a 1:1 ratio of soil and deionized water in cups with pre-measured volumes, which were re-stirred and tested 
after resting for 15 minutes (Adamchuk et al. 1999). Meters were calibrated each day before going into the field with two-point calibration. One point of calibration was neutral $\mathrm{pH} 7$, and the second point was a $\mathrm{pH} 4$ buffer due to the acidic nature of hemlock forest soils. Mineral soil volumetric water content (VWC) was measured with a FieldScout TDR100 Soil Moisture Meter (Spectrum Technologies, Aurora, Illinois). If needed, the soil testing area was compressed by hand prior to sampling to minimize air content in the soil, which can result in inaccurate VWC estimates (Spectrum Technologies 2008). Ten readings were taken at each point to produce an average VWC estimate for each sample. Leaf litter and duff depth was measured $1 \mathrm{~m}$ in front of each coverboard set and rounded to the nearest $0.5 \mathrm{~cm}$. Percent canopy cover was measured at the center of each coverboard grid using a convex spherical densiometer (Forestry Suppliers, Jackson, Mississippi) facing toward the plot center and averaged for the plot.

Weather variables. - Weather conditions were recorded for all environmental data collection and salamander surveys. Ambient air temperature and relative humidity were recorded at the plot center using a Kestrel 3000 weather meter (Kestrel Instruments, Boothwyn, Pennsylvania). Cloud cover at the start of the survey was assessed visually and given a qualitative value: none $(0-5 \%$ cover $)$, partly $(5-50 \%)$, mostly $(50-95 \%)$, or full $(95-100 \%)$. Whether or not precipitation had occurred in the area in the prior 24 hours to the site visit was also recorded using the one-day observed precipitation data provided by the National Weather Service (https://water.weather.gov/precip/). 


\section{Imidacloprid Exposure}

Soil sampling. - In spring 2020, soil was collected in each plot and sent to the U.S. Geological Survey (USGS) Neonicotinoid Laboratory in Sacramento, California to test for imidacloprid and two common imidacloprid metabolites: imidacloprid urea and imidacloprid olefin. Soil cores were collected by removing leaf litter from the soil surface and inserting a $2.54 \mathrm{~cm}$ diameter soil core probe. Sixteen soil cores were systematically collected in each plot, with each point occurring $3.5 \mathrm{~m}$ from the subplot center outward toward each subplot corner. The 16 cores were homogenized into one soil sample per plot.

Soil imidacloprid extraction and quantification. - In the USGS lab, ca. five grams of freeze-dried, homogenized soil was extracted per sample and mixed with carbon $(500 \mathrm{mg})$ and magnesium sulfate $(900 \mathrm{mg})$. Samples were then spiked with a surrogate (imidacloprid- $\mathrm{d}_{4}$; Cambridge Isotope, Andover, MA) and extracted using acetonitrile (ACN) solvent (1500 psi; $\left.100^{\circ} \mathrm{C}\right)$. Nitrogen gas was then used to reduce the extracts. The final extract was centrifuged to remove unwanted particulates, then evaporated to $0.2 \mathrm{~mL}$ and stored in a freezer at $-20{ }^{\circ} \mathrm{C}$ until analysis.

Samples were analyzed using liquid chromatography tandem mass spectrometry (LCMS/MS). Compound flow rate was $0.6 \mathrm{~mL}$ per minute set at $30{ }^{\circ} \mathrm{C}$. Mobile phases were ACN (A) and water with five millimolar (mM) formic acid (B). The gradient of the column was $2 \%$ (A): $98 \%$ (B) from 0 to 2 minutes; increased to $50 \%$ (A): $50 \%$ (B) for 2 to 4 minutes and held for 3 minutes; 7 to 7.5 minute decrease back to $2 \%$ (A): $98 \%$ (B) and held for 4.5 minutes for a total processing time of 12 minutes. Detection level for this method was $0.2 \mathrm{ng} / \mathrm{g}$, with surrogate recovery used to assess the performance of the analysis. A more detailed and technical description of the LC-MS/MS analysis can be found in Hladik and Calhoun (2012). 
Salamander sampling for imidacloprid bioaccumulation. - An exploratory analysis was conducted to examine if imidacloprid could be detected in $P$. cinereus captured in hemlock forests treated with imidacloprid. Eight individuals were captured opportunistically from three treatment areas, at least $50 \mathrm{~m}$ from the edge of research plots, in fall 2018 (West Virginia University IACUC protocol number 1602000309; West Virginia Department of Natural Resources Scientific Collection Permit Number 2018.139). Salamanders were kept frozen until August 2019 and then sent overnight to the USGS Neonicotinoid Laboratory in Sacramento. In the lab, each animal was dehydrated, ground to a fine powder, and analyzed individually using LC-MS/MS for the presence of imidacloprid and two common imidacloprid metabolites: imidacloprid urea and imidacloprid olefin.

\section{Statistical Analyses}

We used linear mixed-effects models to investigate whether imidacloprid influenced salamander relative abundance at the plot level. Salamander response data sets included adult Plethodon cinereus (PLCI), total adults/subadults (PLCI and Plethodon glutinosus [PLGL]; hereafter total adults), and total juveniles (PLCI and PLGL). We were unable to assess juvenile PLCI and to separate age classes of PLGL due to small sample sizes. We considered individuals to be juveniles if the SVL measurement was $<28.5 \mathrm{~mm}$ for PLCI, and $<31 \mathrm{~mm}$ for PLGL, which represents the expected size cutoff for first-year juveniles (Highton 1962, Nagel 1977). For each data set, our relative abundance response variable was salamander captures-per-unit-effort (CPUE) per plot per sample year, which was calculated by dividing total detections by the number of surveys for that year. We treated plot as a random effect in the linear mixed effects models to control for non-independence due to repeated plot observations across years. 
We used linear regression models to investigate imidacloprid effects on salamander body condition index (BCI) at the plot level. Salamander response data sets were the same as the CPUE datasets (i.e., adult PLCI, total adults, total juveniles). Our BCI response variable was calculated using a linear regression model with log-transformed mass and log-transformed SVL (Schulte-Hostedde et al. 2005). We extracted and standardized the residuals from the linear model, which represents the difference between the observed and expected mass for each individual salamander (Plăiaşu et al. 2010). Negative BCI scores represent a body condition that is less than what is expected, while positive scores indicate a BCI that is higher than what is expected based on linear regression. We standardized the BCI scores separately for each species and age class because of the differences in the relationships between length and mass for each species. BCI values that had a standard deviation $>4$ were considered extreme outliers and removed from the dataset (Adult PLCI $n=6$; Total adults $n=6$; Total juveniles $n=2 ; 0.01 \%$ of all observations), as these values likely represented incorrect SVL or mass measurements. For the $\mathrm{BCI}$ linear regression models, we assessed assumptions of normality using quantile-quantile plots and homoscedasticity using residual plots (Zuur et al. 2010). We used Welch's $t$-test (Welch 1947) for unequal variances to compare mean body condition indices of adult PLGL ( $\mathrm{n}=$ 41), juvenile PLGL ( $\mathrm{n}=36)$, and juvenile PLCI $(\mathrm{n}=140)$ between control and treatment plots because number of captures was too small to individually test these groups with the linear regression models.

Candidate environmental predictors included soil $\mathrm{pH}\left(\right.$ converted to $\mathrm{H}^{+}$), soil moisture (VWC), soil depth (duff depth and litter depth combined), canopy cover (\%), total tree DBH $(\mathrm{cm})$ in the plot, and mean number of cover objects searched in the plot. Candidate imidacloprid predictors included treatment (a categorical variable representing whether the site was located in 
a treated or non-treated area), treated tree DBH (i.e., total DBH of treated trees in the plot), and years since treatment (YST; i.e., mean number of years since trees in the plot were treated). We standardized all continuous variables to facilitate model convergence. We used a three-stage model selection process to select the most informative environmental and imidacloprid predictors. In the first stage, we ranked individual environmental predictors using Akaike's information criterion corrected for small sample size (AICc). For the second stage, we used the two most supported environmental variables as an additive and interaction term and then ranked those terms against the singular environmental covariate models. This additional step ensured we were carrying the minimal number of environmental covariates with the highest explanatory power into the imidacloprid model. In the third stage, we used the most parsimonious environmental predictor model as the null model to assess imidacloprid effects.

We had two sets of analyses for each CPUE and BCI analysis. The first analysis included all control and treatment plots to determine if treatment presence and treated tree DBH influenced CPUE and BCI. The second analysis was restricted to treatment plots to test the imidacloprid predictor YST, but we accounted for the potential influence of treatment intensity by including candidate models with additive and interaction effects between YST and treated tree DBH. For both focal model selections, we ranked individual imidacloprid predictors using $\mathrm{AIC} c$. For the most supported models $(\triangle \mathrm{AIC} c<2)$, the direction (negative or positive), magnitude (slope), and strength of the effect ( $85 \%$ confidence interval) were assessed by examining specific model parameters. We conducted all analyses using program R (version 3.6.3). We created linear mixed effects models using the package lme4 (version 1.1-21), ranked models using the package AICcmodavg (version 2.1-1; Mazerolle 2019), and plotted results using the package jtools (version 2.1.3). 


\section{RESULTS}

We detected a total of 920 individuals from 10 species, with 457 detections in control plots and 463 detections in treatment plots (Table 2-1). Only PLCI and PLGL had sufficient detections to be used in our analyses. Adult and juvenile PLCI were detected at 32 control and 31 treatment plots. Adult and juvenile PLGL were detected at 13 control and 15 treatment plots.

Imidacloprid was detected in the soil at 11 of the 18 treatment plots (Table 2-2) and had a mean concentration of $28.36 \pm 63.24 \mathrm{ng} / \mathrm{g}$. Imidacloprid olefin and imidacloprid urea was detected in one and two plots, respectively. Both plots with imidacloprid olefin and imidacloprid urea also had detectable imidacloprid concentrations. Imidacloprid was not detected at any control plots. Two treatment plots did not contain any treated trees within the plot boundary but had treated trees just outside the sample plot boundary. Mean surrogate recovery scores for the soil imidacloprid concentration analysis was $46 \%$ (range $=29-72 \%$ ). Due to generally low recovery rates, we did not use soil concentration as an environmental predictor in analyses.

\section{Environmental Predictors}

The environmental variables with the most influence on CPUE and BCI differed among salamander groups. For CPUE of adult PLCI and total adults, the most parsimonious model included an interaction term derived from canopy cover and mean cover objects $\left(\mathrm{w}_{i}=0.98\right.$ and 1.00, respectively; Table 2-3). For CPUE of total juveniles, the most parsimonious model included canopy cover $\left(\mathrm{w}_{i}=0.39\right.$; Table $\left.2-3\right)$. For BCI, the most parsimonious model for adult PLCI and total adults included an interaction term derived from mean number of cover objects 
and total plot $\mathrm{DBH}\left(\mathrm{w}_{i}=0.68\right.$ and 0.51 , respectively; Table $\left.2-4\right)$. The most parsimonious model for total juvenile BCI was the intercept-only model $\left(\mathrm{w}_{i}=0.23\right.$; Table $\left.2-4\right)$.

\section{Imidacloprid Effects (Control and Treatment Plots)}

Salamander CPUE. - Adult PLCI mean CPUE was $1.22 \pm 1.14$ in control sites and $1.23 \pm 1.14$ in treatment sites (Table 2-1). Total adult mean CPUE was $1.30 \pm 1.21$ in control sites and $1.31 \pm$ 1.28 in treatment sites (Table 2-1). Total juvenile mean CPUE was $0.32 \pm 0.37$ in control sites and $0.35 \pm 0.31$ in treatment sites (Table 2-1). The most supported CPUE model for all three groups was treated tree DBH (Table 2-5). All models estimated that CPUE increased with treated tree $\mathrm{DBH}$, but the confidence intervals widely overlapped 0 , suggesting lack of a strong relationship (Table 2-6).

Salamander BCI. - The most supported BCI model for all three groups was the intercept-only model, but treatment presence and treated tree DBH was also well-supported in all three groups (Table 2-5). In adult PLCI and total adults (PLCI and PLGL), BCI decreased with treatment presence and higher treated tree $\mathrm{DBH}$, but the confidence intervals overlapped 0 (Table 2-6). In total juveniles, BCI decreased with treated tree DBH but increased with treatment presence (Table 2-6). However, the confidence intervals for both predictors widely overlapped 0 (Table 2-6).

We detected a total of 41 adult and 36 juvenile PLGL (Table 2-7). Mean adult PLGL BCI in control plots was not significantly different from treatment plots $(t=-0.90, d f=35.10, p=$ 0.37). Mean juvenile PLGL BCI in control plots was $-0.12(\mathrm{sd}=0.27$, range $=-0.54-0.26$; Table 2-7) and 0.08 in treatment plots $(\mathrm{sd}=0.32$, range $=-0.55-0.72$; Table 2-7), which was trending toward significantly different $(t=-1.97, d f=31.68, p=0.06)$. Mean juvenile PLCI BCI 
in control plots was $0.01(\mathrm{sd}=0.26$, range $=-0.81-0.57$; Table 2-7) and -0.01 in treatment plots $(\mathrm{sd}=0.26$, range $=-0.61-0.55 ;$ Table $2-7)$, which was not significantly different $(t=0.52, d f=$ 137.97, $p=0.60)$.

\section{Imidacloprid Effects (Treatment Plots-only)}

Salamander CPUE. - The most supported model for adult PLCI and total adult CPUE was YST (Table 2-8). The most supported model for total juveniles CPUE was the null model, followed by YST (Table 2-8). For all groups, CPUE increased with YST, but the predictor confidence intervals overlapped 0, suggesting a weak influence of YST on CPUE (Table 2-9).

Salamander BCI. - The most supported model for adult PLCI and total adults BCI was the interaction model that included YST and treated tree DBH (Table 2-8). When examining the singular terms within the interaction models, BCI increased with YST (Figure 2-3a) and decreased with treated tree DBH (Figure 2-3b), and the confidence intervals for all predictors did not overlap 0 (Table 2-9). The model indicated that total treated tree DBH had an initial negative impact on BCI, but plots with greater treatment intensities had a stronger positive YST

relationship, resulting in similar BCI scores after 8 YST between low and high total treated tree DBH plots (Table 2-9; Figure 2-3c). The most supported model for total juveniles was the null model, with the YST model also receiving support (Table 2-8). The YST model estimated that total juvenile BCI decreased as YST increased, but the confidence interval overlapped 0 (Table 2-9). 


\section{Salamander Imidacloprid Bioaccumulation}

All eight PLCI that were collected from eastern hemlock treated areas had detectable levels of imidacloprid (Table 2-10). Whole-body concentrations ranged from $9.13-49.43 \mathrm{ng} / \mathrm{g}$ dry weight $($ mean $=30.63 \mathrm{ng} / \mathrm{g})$. Imidacloprid urea and imidacloprid olefin were not detected in any of the samples. The four PLCI collected from the Fern Creek treatment area (near FC sites in Table 22), were exposed to relatively frequent and high application rates of imidacloprid. Three PLCI were collected from the Richmond Chapel treated area and had imidacloprid concentrations of $16.31,17.74$, and $30.17 \mathrm{ng} / \mathrm{g}$ dry weight, respectively. The soil sample from the Richmond Chapel treatment plot had an imidacloprid concentration of $2.04 \mathrm{ng} / \mathrm{g}$ dry weight. One PLCI was collected from the Summersville Dam treatment area and had an imidacloprid concentration of 43.56 ng/g dry weight. The two Summersville Dam treatment plots had imidacloprid concentrations of 4.36 and $0.64 \mathrm{ng} / \mathrm{g}$ dry weight.

\section{DISCUSSION}

In contrast to our hypothesis, the results of this study did not indicate that salamander CPUE or BCI was strongly influenced by whether or not plots were located in areas treated with imidacloprid. However, we did detect potential negative impacts of imidacloprid treatments when we incorporated differences in treatment intensity and time since treatment, particularly for BCI. When we accounted for differences in the amount of imidacloprid applied and time since treatment, we found that treatment intensity initially had a strong negative effect on BCI, but that high intensity plots had a stronger recovery response, achieving similar predicted BCI scores as low intensity plots by 8 YST. Our finding that BCI of adult PLCI was negatively associated with treated tree $\mathrm{DBH}$ is consistent with previous research in this study system that focused on stream 
salamanders, which found that body condition of 5 species decreased with increasing imidacloprid concentration in streams (Crayton et al. 2020). In addition, we found that BCI response to imidacloprid treatments for terrestrial salamanders was dependent on salamander age class. For example, BCI of adult PLGL and juvenile PLCI did not have a negative association with whether the plot was treated or untreated, but juvenile PLGL BCI was significantly higher in treated than untreated areas. However, our sample sizes were small for these sample groups and more research is needed to more fully understand age class-specific responses.

We detected imidacloprid in all 8 woodland salamanders collected from treated areas, and Crayton et al. (2020) detected imidacloprid in 47 of 107 stream salamanders collected from treated and untreated areas, 44 were from treated areas. Three salamanders tested positive for imidacloprid but were captured in untreated areas that were located $350 \mathrm{~m}$ from the nearest treatment site. Interestingly, 53 of 60 salamanders that did not test positive for imidacloprid presence were captured in sites with detectable levels of imidacloprid in the stream. Uptake of pesticides in other amphibian species has been found to impact their health (Khan and Law 2005, Henson-Ramsey et al. 2008, Van Meter et al. 2014, 2015). It is possible that imidacloprid uptake is directly impacting salamander health in our study system, reflected in lower BCI scores found in some species in this study, and both lower BCI scores and increased concentrations of the stress hormone corticosterone found in Crayton et al. (2020).

Pesticide exposure studies focusing on amphibians are largely centered around sublethal, single-species physiological impacts in laboratory settings. Abundance or population level impact studies with wild amphibian populations are still rare, with long-term, field-based exposure effect studies being even more uncommon. Population level effects from pesticides are widely documented in amphibian species. In California, several frog species declines were linked 
to pesticide drift in the 1990s (Sparling et al. 2001, Davidson 2004). A die-off event of Oregon spotted frogs (Rana pretiosa) was linked to widespread dichlorodiphenyltrichloroethane (DDT) spraying in Oregon in 1974 (Kirk 1988). Elevated concentrations of organophosphorus pesticides were deemed a causal or contributing factor in frog population declines when compared to control site populations in Ontario, Canada (Bishop et al. 1999). Amphibian population vulnerability to contaminants such as DDT and chlorpyrifos is well documented, with amphibians containing the most vulnerable species in a comparison study with 144 other vertebrates (De Lange et al. 2010). However, several studies have documented the ability of amphibians to adapt to toxicants, sometimes at the expense of their health.

In some situations, long-term sublethal exposure to a contaminant could be a catalyst for natural selection within and among populations or communities. Bridges and Semlitsch (2000) observed significant differences in pesticide-induced time to death and behavioral activity among several frog species, in a single Lithobates sphenocephalus population, and among several $R$. sphenocephala populations. They theorized that some frog species, and some populations within a single species, can develop a tolerance to pesticide exposure if the environmental concentrations are within a sublethal effect range. In another study, wood frog (Lithobates sylvaticus) populations located closer to agricultural areas showed higher resistance to a common organophosphate insecticide (chlorpyrifos) than populations located further from agricultural areas (Cothran et al. 2013). Hopkins et al. (2013) found significant local adaptions in some rough-skinned newt populations to road de-icing salt exposure. In this study, the survival response rate was extremely variable, with some portions of a single population exhibiting 84$100 \%$ survival while other portions had $0 \%$ survival in the same treatment. However, the cost of survival resulted in impacts to fitness that included premature hatching that led to impaired 
development rates. The results of our study are potentially consistent with other amphibian toxicant resistance responses, where overall relative abundance is not impacted by exposure at the cost of individual salamander health.

In addition to direct mortality, declines in populations could be caused by behavioral responses or reduced reproductive success (Bishop et al. 1999; reviewed in Gibbons et al. 2012). Spatial avoidance of contaminants has been documented in laboratory settings with amphibians (reviewed in Araújo and Blasco 2018). In a natural setting, this could translate to dispersal from a site with pesticide contamination. To our knowledge, Crayton (2019) is the only other study that has examined abundance responses of wild salamander populations exposed to realistic field concentrations of imidacloprid. Crayton (2019) did not find strong support for negative impacts of imidacloprid treatments on abundance of stream salamander species, but she did not assess the potential influence of YST. Similar to Crayton (2019), we did not detect a strong difference in relative abundance between plots that were or were not located in areas treated with imidacloprid. This suggests that woodland salamanders are likely not dispersing from treated areas, and that local populations are able to persist in treated areas even though their body condition declines.

The effects of imidacloprid on salamander BCI in this study are consistent with other studies investigating links between pesticide exposure and declines in amphibian body condition. Body condition is widely used as a non-destructive method to make inferences about prey availability and quality, overall habitat quality, and potential presence of environmental stressors for focal taxa (Pope and Matthews 2002, Băncilă et al. 2010, Roznik et al. 2015, Iglesiascarrasco et al. 2017). It is associated with fitness and is considered a proxy metric to estimate energy reserves, reproductive health, stress response, and immune health (Roff 1993, Rollins- 
Smith and Woodhams 2012). Reductions in prey abundance and diversity are associated with impacts to woodland salamander health and development (Johnson and Wallace 2005, Becker and Harris 2010, Roznik et al. 2015). We observed a decrease in salamander BCI scores with higher total treated tree $\mathrm{DBH}$ and found that $\mathrm{BCI}$ scores increased with time since treatment. Decreases in BCI scores of adult salamanders in treatment areas may be attributed to a decrease in food resource availability (Mathis 1990, Gabor and Jaeger 1995), in addition to direct toxic effects from exposure to the pesticide. Ants are a primary food source for woodland salamanders (Jameson 1944, Burton 1976, Pauley 1978, Jaeger 1990). In Chapter 3, we found that ant abundance (Aphaenogaster picea) was significantly lower in treatment plots compared to control plots, providing evidence that a food source for woodland salamanders is impacted by imidacloprid treatments. In addition, ant abundance increased with increasing number of years since treatment, which may be a contributing factor to the observed increase in BCI over time for salamanders in treatment plots.

We conducted soil chemical analyses for the purpose of validating presence of imidacloprid in treated areas and lack of imidacloprid at control sites. However, we chose not to use soil imidacloprid concentration as a candidate imidacloprid predictor in our study. We were only able to collect one sample from each plot, which represented an aggregation of 16 soil core samples. Thus, we were unable to capture the spatiotemporal dynamics of imidacloprid within each plot in order to fully characterize exposure levels. Importantly, woodland salamanders are long-lived animals. For example, Hairston (1983) estimated that mean generation time for Plethodon jordani was 9.8 years. Thus, some individuals captured during our study may have been alive when imidacloprid treatments began in NERI, and soil concentrations in treated plots have undoubtedly changed over time (Cowles et al. 2006, Reynolds 2008, Knoepp et al. 2012). 
In addition, sorption-desorption and its relationship with specific soil properties and processes have been found to be dependent on many environmental variables, such as organic carbon content, clay content, and soil $\mathrm{pH}$, and the relationships can be highly variable even between samples taken within a single site (Papiernik et al. 2006, Reynolds 2008, Knoepp et al. 2012). Thus, a single point sample for the plot is likely not an accurate predictor of imidacloprid exposure over space and time.

The results of the exploratory bioaccumulation analysis suggest that PLCI adults are absorbing imidacloprid, but the exact uptake mechanism is currently unknown. There are several potential pathways for amphibians to uptake imidacloprid. Their thin dermal layer that allows for the exchange of gas and moisture with their environment also makes them susceptible to absorbing environmental contaminants, such as pesticides (Quaranta et al. 2009). Amphibian embryonic development is highly affected by the soil in which their permeable, non-amniotic eggs are laid, and provide a pathway for pesticide uptake (Petranka 2010, Boone 2018). Water is an additional pathway for amphibians to uptake pesticides via the same dermal exchange processes that occur with soil (Brühl et al. 2011, Van Meter et al. 2014b, 2015). The ingestion of contaminated prey could also be a potential contributing factor to salamanders bioaccumulating imidacloprid. In one laboratory study, two salamander species (Ambystoma tigrinum and A. maculatum) were fed earthworms that were reared in soil treated with polychlorinated biphenyl mixture (PCB). Salamanders bioaccumulated more PCBs from the ingestion of contaminated prey compared to salamanders exposed to the contaminants through dermal exposure only (Johnson et al. 1999). Hall and Swineford (1979) fed mealworms treated with varying levels of methoxychlor to Anaxyrus americanus and found that toads bioaccumulated the insecticide via ingestion. Interestingly, they found that toads that were exposed to the same treatment level of 
mealworms (low and high methoxychlor) had the same bioaccumulation concentrations regardless of the number of days they were fed the mealworms. In another study, researchers fed crickets that were exposed to a range of concentrations of per- and polyfluoroalkyl substances (PFAS) to A. tigrinum and found that the concentration of PFAS in salamanders increased with the treatment dosages applied to the crickets (low, medium, and high). Additionally, they found A. tigrinum body condition to be impacted from increasing levels of the contaminants, as well (Flynn et al. 2021).

The impacts of imidacloprid bioaccumulation on salamander health should be explored further, especially regarding potential cellular level effects. Previous studies have shown genotoxic effects to amphibians exposed to low level concentrations of imidacloprid (Feng et al. 2004, Pérez-Iglesias et al. 2014, Ruiz de Arcaute et al. 2014), though salamanders were not used in these studies. Over time, genotoxic effects can lead to sublethal and lethal effects that can include mutations, decreased survivability, impacts to fitness, and altered behavior (Dubois 1979, Brodeur et al. 2012, Alton and Franklin 2017). Stress from single or multiple environmental contaminants, such as pesticides, can cause immunosuppression in amphibians, making them more susceptible to disease (Blaustein et al. 2003, Gilbertson et al. 2003, Relyea 2004, Sih et al. 2004, Hayes et al. 2006, Albert et al. 2007).

The results of this study may assist resource managers in making forest management decisions in areas that include the range of endangered, threatened, rare, or other species of concern, such as the federally threatened Cheat Mountain salamander (Plethodon nettingi) and Cow Knob salamander (Plethodon punctatus). Neither species are found in NERI or GARI, but they occur in the Allegheny Mountain and Ridge and Valley physiographic regions of West Virginia located to the northeast of the NPS units. Cheat Mountain salamanders are associated 
with high elevation red spruce and mixed red spruce-eastern hemlock stands (Dillard 2007). Cow Knob salamanders are also found in high elevation forests that contain eastern hemlock (Graham 2007, Jacobsen 2019). Eastern red-backed salamanders could potentially serve as a proxy species for Cheat Mountain salamander and Cow Knob salamander in a cost-benefit assessment examining the impact of imidacloprid treatment versus the impact of hemlock loss due to HWA.

The goal of this research project was to determine whether imidacloprid treatments in hemlock forests in NERI and GARI are influencing abundance and body condition of woodland salamanders. Our findings indicate there are effects on salamander body condition, but not relative abundance. We recommend ongoing study on the potential impacts of imidacloprid to salamander relative abundance, as the results of the bioaccumulation analysis and impacts to body condition found in this research project could extend to abundance related impacts in the future. The movement of imidacloprid through the food web via terrestrial salamanders is a research topic that could be explored further. Our study indicates that treatment intensity influences the strength of impacts on salamander body condition, and thus we recommend forest managers be cognizant of the size and spacing of trees being treated within treatment zones. For example, decreasing the amount of imidacloprid applied within an area by staying on the lower end of the treated tree DBH per acre recommendations may lessen impacts on health of woodland salamander species. The optimized dosage in Benton et al. (2016) that NERI began using in 2017 recommends staying within 362 Coretect $^{\circledR}$ tablets per acre or 181 ounces of water soluble imidacloprid packets per acre. Based on our results, staying within recommended ranges outlined in Benton et al. (2016) would have the least impact to salamander body condition while protecting eastern hemlocks against the impacts of HWA. Where possible, we also recommend 
spacing the treatments out over a wider area within the treatment acre, so as not to apply the bulk

of the treatment allowance in a small area.

\section{Literature Cited}

Adamchuk, V. I., M. T. Morgan, and D. R. Ess. 1999. An automated sampling system for measuring soil $\mathrm{pH}$. Transactions of the ASAE 42:885-891.

Ade, C. M., M. D. Boone, and H. J. Puglis. 2010. Effects of an insecticide and potential predators on green frogs and northern cricket frogs. Journal of Herpetology 44:591-600.

Albert, A., K. Drouillard, G. D. Haffner, and B. Dixon. 2007. Dietary exposure to low pesticide doses causes long-term immunosuppression in the leopard frog (Rana pipiens). Environmental Toxicology and Chemistry 26:1179-1185.

Alton, L. A., and C. E. Franklin. 2017. Drivers of amphibian declines: effects of ultraviolet radiation and interactions with other environmental factors. Climate Change Responses 4:126. Climate Change Responses.

Araújo, C. V. M., and J. Blasco. 2018. Spatial avoidance as a response to contamination by aquatic organisms in nonforced, multicompartmented exposure systems: A complementary approach to the behavioral response. Environmental Toxicology and Chemistry 38:312320.

Băncilă, R. I., T. Hartel, and $\mathrm{Pl}^{\sim}$ aia su. su. 2010. Comparing three body condition indices in amphibians; a case study of yellow-bellied toad Bombina variegata. Amphibia-Reptilia $00: 1-5$.

Becker, M. H., and R. N. Harris. 2010. Cutaneous bacteria of the redback salamander prevent morbidity associated with a lethal disease. PLoS ONE 5:1-6.

Benton, E., J. F. Grant, R. Cowles, J. Webster, R. Nichols, A. Lagalante, and C. Coots. 2016. Assessing relationships between tree diameter and long-term persistence of imidacloprid and olefin to optimize imidacloprid treatments on eastern hemlock. Forest Ecology and Management 370:12-21.

Best, M. L. M., and H. H. Welsh, Jr. 2014. The trophic role of a forest salamander: impacts on invertebrates, leaf litter retention, and the humification process. Ecosphere 5:1-19.

Bishop, C. A., N. A. Mahony, J. Struger, P. Ng, and K. E. Pettit. 1999. Anuran development, density and diversity in relation to agricultural activity in the holland river watershed, ontario, canada (1990-1992). Environmental Monitoring and Assessment 57:21-43.

Blaustein, A. R., J. M. Romansic, J. M. Kiesecker, and A. C. Hatch. 2003. Ultraviolet radiation, toxic chemicals and amphibian population declines. Diversity and Distributions 9:123-140. Wiley.

Boone, M. D. 2018. An amphibian with a contracting range is not more vulnerable to pesticides in outdoor experimental communities than common species. Environmental Toxicology and Chemistry 37:2699-2704.

Bridges, C. M., and R. D. Semlitsch. 2000. Variation in pesticide tolerance of tadpoles among and within species of ranidae and patterns of amphibian decline. Conservation Biology 14:1490-1499. 
Brühl, C. A., S. Pieper, and B. Weber. 2011. Amphibians at risk? Susceptibility of terrestrial amphibian life stages to pesticides. Environmental Toxicology and Chemistry 30:24652472.

Brodeur, J. C., J. V. Candioti, S. Soloneski, M. L. Larramendy, and A. E. Ronco. 2012. Evidence of reduced feeding and oxidative stress in common tree frogs (Hypsiboas pulchellus) from an agroecosystem experiencing severe drought. Journal of Herpetology 46:72-78.

Buck, L., P. Lambdin, D. Paulsen, J. Grant, and A. Saxton. 2005. Insect species associated with eastern hemlock in the Great Smoky Mountains National Park and environs. Journal of the Tennessee Academy of Science 80:60-69.

Burton, T. M., and G. E. Likens. 1975a. Salamander populations and biomass in the Hubbard Brook Experimental Forest, New Hampshire. Copeia 3:541-546.

Burton, T. M., and G. E. Likens. 1975b. Energy flow and nutrient cycling in salamander populations in the Hubbard Brook Experimental Forest, New Hampshire. Ecology 56:10681080.

Cheah, C., M. E. Montgomery, R. C. Reardon, and B. Onken. 2004. Biological control of hemlock woolly adelgid. USDA Forest Service, Forest Health Technology Enterprise Team, Morgantown, WV.

Cothran, R. D., J. M. Brown, and R. A. Relyea. 2013. Proximity to agriculture is correlated with pesticide tolerance: Evidence for the evolution of amphibian resistance to modern pesticides. Evolutionary Applications 6:832-841.

Cowles, R. S., M. E. Montgomery, and C. S.-J. Cheah. 2006. Activity and residues of imidacloprid applied to soil and tree trunks to control hemlock woolly adelgid (Hemiptera: Adelgidae) in forests. Journal of Economic Entomology 99:1258-1267.

Crayton, S. M. 2019. Stream salamander and benthic macroinvertebrate community responses to imidacloprid exposure. Thesis, West Virginia University, Morgantown, West Virginia, USA.

Crayton, S. M., P. B. Wood, D. J. Brown, A. R. Millikin, T. J. McManus, T. J. Simpson, K-M. $\mathrm{Ku}$, and Y-L. Park. 2020. Bioaccumulation of the pesticide imidacloprid in stream organisms and sublethal effects on salamander. Global Ecology and Conservation 24:e01292.

Danis, B. E. G., and V. L. Marlatt. 2021. Investigating acute and subchronic effects of neonicotinoids on northwestern salamander larvae. Archives of Environmental Contamination and Toxicology 80:691-707.

Davidson, C. 2004. Declining downwind: amphibian population declines in California and historical pesticide use. Ecological Applications 14:1892-1902.

Dillard, L. O. 2007. Distribution and habitat of the threatened cheat mountain salamander (Plethodon nettingi) at multiple spatial scales in West Virgina forests. Thesis, University of Wisconsin, Stevens Point, Wisconsin, USA.

Dilling, C., P. Lambdin, J. Grant, and L. Buck. 2007. Insect guild structure associated with eastern hemlock in the southern Appalachians. Environmental entomology 36:1408-1414.

Dilling, C., P. Lambdin, J. Grant, and R. Rhea. 2009. Community response of insects associated with eastern hemlock to imidacloprid and horticultural oil treatments. Environmental Entomology 38:53-66.

Dodd, C.K., Jr. 2003. Monitoring Amphibians in Great Smoky Mountains National Park. US Geological Survey Circular 1258. Florida Integrated Science Center, Tallahassee, FL. 118 pp. 
Dubois, A. 1979. Anomalies and mutations in natural populations of the Rana esculenta complex (Amphibia, Anura). Mitteilungen aus dem Zoologischen Museum in Berlin 55:59-87.

Elliott, W. M., N. B. Elliott, and R. L. Wyman. 1993. Relative effect of litter and forest type on rate of decomposition. American Midland Naturalist 129:87-95.

Ellison, A. M., J. Chen, D. Díaz, C. Kammerer-burnham, and M. Lau. 2005. Changes in ant community structure and composition associated with hemlock decline in New England. Pages 280-289 in Proceedings of Third Symposium on Hemlock Woolly Adelgid. USDA Forest Service, Forest Health Technology Enterprise Team, Morgantown, West Virginia.

Feng, S., Z. Kong, X. Wang, L. Zhao, and P. Peng. 2004. Acute toxicity and genotoxicity of two novel pesticides on amphibian, Rana $n$. hallowell. Chemosphere 56:457-463.

Finzi, A. C., N. Van Breemen, and C. D. Canham. 1998. Canopy tree-soil interactions within temperate forests: Species effects on soil carbon and nitrogen. Ecological Applications 8:440-446.

Flynn, R. W., T. D. Hoskins, M. Iacchetta, C. De Perre, L. S. Lee, J. T. Hoverman, and M. S. Sepulveda. 2021. Dietary exposure and accumulation of per- and poly fluoroalkyl substances alters growth and reduces body condition of post-metamorphic salamanders. Science of the Total Environment 765:142730.

Gabor, C. R., and R. G. Jaeger. 1995. Resource quality affects the agonistic behaviour of territorial salamanders. Animal Behaviour 49:71-79.

Gibbons, D., C. Morrissey, and P. Mineau. 2015. A review of the direct and indirect effects of neonicotinoids and fipronil on vertebrate wildlife. Environmental Science and Pollution Research International 22:103-118.

Gilbertson, M., G. D. Haffner, K. G. Drouillard, A. Albert, and B. Dixon. 2003. Immunosuppression in the northern leopard frog (Rana pipiens) induced by pesticide exposure. Environmental Toxicology and Chemistry: An International Journal 22:101-110. Wiley Online Library.

Gouger, R. J. 1971. Control of Adelges tsugae on hemlock in Pennsylvania. Scientific Tree Topics 3:6-9.

Graham, M. R. 2007. Distribution and conservation genetics of the Cow Knob salamander, Plethodon punctatus. Thesis, Marshall University, Huntington, West Virginia, USA.

Green, N. B., and T. K. Pauley. 1987. Amphibians and Reptiles in West Virginia. University of Pittsburgh Press, Pittsburgh, Pennsylvania, USA.

Hadley, J. L. 2000. Understory microclimate and photosynthetic response of saplings in an oldgrowth eastern hemlock (Tsuga canadensis L.) forest. Ecoscience 7:66-72.

Hairston, N. G. 1983. Growth, survival and reproduction of Plethodon jordani: trade offs between selective pressures. Copeia 1983:1024-1035.

Hall, R. J., and D. Swineford. 1979. Uptake of methoxychlor from food and water by the American toad (Bufo americanus). Bulletin of Environmental Contamination and Toxicology 23:335-337.

Havill, N. P., L. C. Vieira, and S. M. Salom. 2014. Biology and Control of Hemlock Woolly Adelgid. USDA Forest Service, Forest Health Technology Enterprise Team, Morgantown, West Virginia.

Hayes, T. B., P. Case, S. Chui, D. Chung, C. Haeffele, K. Haston, M. Lee, V. P. Mai, Y. Marjuoa, J. Parker, and M. Tsui. 2006. Pesticide mixtures, endocrine disruption, and amphibian declines: Are we underestimating the impact? Environmental Health Perspectives 114:40-50. 
Henson-Ramsey, H., S. Kennedy-Stoskopf, J. F. Levine, S. K. Taylor, D. Shea, and M. K. Stoskopf. 2008. Acute toxicity and tissue distributions of malathion in Ambystoma tigrinum. Archives of Environmental Contamination and Toxicology 55:481-487.

Hesed, K.M. 2012. Uncovering salamander ecology: a review of coverboard design. Journal of Herpetology 46:442-450.

Highton, R. 1962. Geographic variation in the life history of the slimy salamander. Copeia 1962:597-613.

Hladik, M., and D. Calhoun. 2012. Analysis of the herbicide Diuron, three Diuron degradates, and six neonicotinoid insecticides in water-Method details and application to two Georgia streams. U.S. Geological Survey Scientific Investigations Report 5206:10.

Hopkins, G. R., S. S. French, and E. D. Brodie. 2013. Potential for local adaptation in response to an anthropogenic agent of selection: Effects of road deicing salts on amphibian embryonic survival and development. Evolutionary Applications 6:384-392.

Hrynyk, M. A., C. Brunetti, L. Kerr, and C. D. Metcalfe. 2018. Effect of imidacloprid on the survival of Xenopus tadpoles challenged with wild type frog virus 3. Aquatic Toxicology 194:152-158.

Iglesias-carrasco, M., J. Martín, and C. Cabido. 2017. Urban habitats can affect body size and body condition but not immune response in amphibians. Urban Ecosystems 20:1331-1338.

Jacobsen, C. D. 2019. Influence of climate change and prescribed fire on habitat suitability and abundance of the high-elevation endemic Cow Knob salamander (Plethodon punctatus). Thesis, West Virginia University, Morgantown, West Virginia, USA.

Jaeger, R. G. 1990. Territorial salamanders evaluate size and chitinous content of arthropod prey. Behavioural Mechanisms of Food Selection 20:111-126.

Jameson, E. W., J. 1944. Food of the Red-Backed Salamander. Copeia 1944:145-147.

Jeschke, P., R. Nauen, M. Schindler, and A. Elbert. 2011. Overview of the status and global strategy for neonicotinoids. Journal of Agricultural and Food Chemistry 59:2897-2908. American Chemical Society, Washington, D.C., USA.

Johnson, M. S., L. S. Franke, R. B. Lee, and S. D. Holladay. 1999. Bioaccumulation of 2,4,6trinitrotoluene and polychlorinated biphenyls through two routes of exposure in a terrestrial amphibian: Is the dermal route significant? Environmental Toxicology and Chemistry 18:873-878.

Johnson, B. R., and J. B. Wallace. 2005. Bottom-up limitation of a stream salamander in a detritus-based food web. Canadian Journal of Fisheries and Aquatic Science 62:301-311.

Julian, S. E. 2000. Effects of chronic pesticide exposure on larval amphibians. Thesis, Applied Ecology and Conservation Biology, Frostburg State University, Frostburg, Maryland, USA.

Kendrick, J. A., R. R. Ribbons, A. T. Classen, and A. M. Ellison. 2015. Changes in canopy structure and ant assemblages affect soil ecosystem variables as a foundation species declines. Ecosphere 6:77.

Khan, M. Z., and F. C. P. Law. 2005. Adverse effects of pesticides and related chemicals on enzyme and hormone systems of fish, amphibians and reptiles: a review. Proc. Pakistan Acad. Sci. 42:315-323.

Kirk, J. J. 1988. Western spotted frog (Rana pretiosa) mortality following forest spraying of DDT. Herpetological Review 19:51-53.

Knoepp, J. D., J. M. Vose, J. L. Michael, and B. C. Reynolds. 2012. Imidacloprid movement in soils and impacts on soil microarthropods in southern Appalachian eastern hemlock stands. Journal of Environmental Quality 41:469-478. 
Kunkel, B. A., D. W. Held, and D. A. Potter. 1999. Impact of halofenozide, imidacloprid, and bendiocarb on beneficial invertebrates and predatory activity in turfgrass. Journal of Economic Entomology 92:922-930.

Kunkel, B. A., D. W. Held, and D. A. Potter. 2001. Lethal and sublethal effects of bendiocarb, halofenozide, and imidacloprid on Harpalus pennsylvanicus (Coleoptera: Carabidae) following different modes of exposure in turfgrass. Journal of Economic Entomology 94:60-67.

De Lange, H. J., J. Lahr, J. J. C. Van der Pol, Y. Wessels, and J. H. Faber. 2010. Ecological vulnerability in wildlife: an expert judgment and multicriteria analysis tool using ecological traits to assess relative impact of pollutants. Environmental Toxicology and Chemistry 28:2233-2240.

Maerz, J. C., V. A. Nuzzo, and B. Blossey. 2009. Declines in woodland salamander abundance associated with non-native earthworm and plant invasions. Conservation Biology 23:975981. Wiley Online Library.

Marshall, J. L., and C. D. Camp. 2006. Environmental correlates of species and genetic richness in lungless salamanders (family plethodontidae). Acta Oecologica 29:33-44.

Marvin, G. A. 2001. Age, growth, and long-term site fidelity in the terrestrial plethodontid salamander Plethodon kentucki. Copeia 2001:108-117.

Mathis, A. 1990. Territoriality in a terrestrial salamander: the influence of resource quality and body size. Behavior 112:162-175.

Mathewson, B. 2009. The relative abundance of eastern red-backed salamanders in eastern hemlock-dominated and mixed deciduous forests at Harvard Forest. Northeastern Naturalist 16:1-12.

Mazerolle, M. 2019. Package "AICcmodavg”. Model selection and multimodel inference based on (Q)AIC(c). Available from https://web.archive.org/web/20190710031635/https://cran.rproject.org/web/packages/AICcmodavg/AICcmodavg.pdf.

McClure, M. S. 1996. Biology of Adelges tsugae and its potential for spread in the northeastern United States. Pages 16-25 in. Proceedings of the First Hemlock Woolly Adelgid Review. Charlottesville, Virginia.

McClure, M. S., S. M. Salom, and K. S. Shields. 1996. Hemlock woolly adelgid. Volume 96. USDA Forest Service, Forest Health Technology Enterprise Team, Morgantown, WV.

Mladenoff, D. J. 1987. Dynamics of nitrogen mineralization and nitrification in hemlock and hardwood treefall gaps. Ecology 68:1171-1180.

Nagel, J. 1977. Life history of the red-backed salamander, Plethodon cinereus, in northeastern Tennessee. Herpetologica 33:13-18.

National Oceanic and Atmospheric Administration. 2016. Summary of Monthly Normals. <http://www.ncdc.noaa.gov/cdo-web/datatools/normals>. Accessed 17 Aug 2020.

Onken, B. P., J. Quimby, R. Evans, and S. Hutchinson. 1994. Work plan for monitoring the impacts of hemlock woolly adelgid on hemlock. USDA Forest Service, Forest Health Technology Enterprise Team. Morgantown, WV, USA.

Orwig, D. A., and D. R. Foster. 2000. Stand, landscape, and ecosystem analyses of hemlock woolly adelgid outbreaks in southern New England: an overview. Proceedings on the symposium on sustainable management of hemlock ecosystems in eastern North America 267:123-125. 
Orwig, D. A., A. A. B. Plotkin, E. A. Davidson, H. Lux, K. E. Savage, and A. M. Ellison. 2013. Foundation species loss affects vegetation structure more than ecosystem function in a northeastern USA forest. PeerJ 1:1-29.

Ousterhout, B. H., and E. B. Liebgold. 2010. Dispersal versus site tenacity of adult and juveniler red-backed salamanders (Plethodon cinereus). Herpetologica 66:269-275.

Papiernik, S. K., W. C. Koskinen, L. Cox, P. J. Rice, S. A. Clay, N. R. Werdin-Pfisterer, and K. A. Norberg. 2006. Sorption-desorption of imidacloprid and its metabolites in soil and vadose zone materials. Journal of Agricultural and Food Chemistry 54:8163-8170.

Pauley, T. K. 1978. Food types and distribution as a plethodon habitat partitioning factor. Bulletin of the Maryland Herpetological Society 14:79-82.

Pérez-Iglesias, J. M., C. Ruiz de Arcaute, N. Nikoloff, L. Dury, S. Soloneski, G. S. Natale, and M. L. Larramendy. 2014. The genotoxic effects of the imidacloprid-based insecticide formulation Glacoxan Imida on Montevideo tree frog Hypsiboas pulchellus tadpoles (Anura, Hylidae). Ecotoxicology and Environmental Safety 104:120-126.

Petranka, J. W. 2010. Salamanders of the United States and Canada. Smithsonian Books, Washington D.C., USA.

Plăiaşu, R., T. Hartel, R. I. Băncilă, D. Cogălniceanu, and J. Smets. 2010. Comparing three body condition indices in amphibians: a case study of yellow-bellied toad Bombina variegata. Amphibia-Reptilia 31:558-562. Brill, Leiden, The Netherlands.

Pope, K. L., and K. R. Matthews. 2002. Influence of anuran prey on the condition and distribution of Rana muscosa in the Sierra Nevada. Herpetologica 58:354-363.

Quaranta, A., V. Bellantuono, G. Cassano, and C. Lippe. 2009. Why amphibians are more sensitive than mammals to xenobiotics. PLoS ONE 4:2-5.

Relyea, R. 2004. Synergistic impacts of malathion and predatory stress on six species of North American tadpoles. Environmental toxicology and chemistry 23:1080-1084.

Reynolds, W. N. 2008. Imidacloprid insecticide treatments for hemlock woolly adelgid, Adelges tsugae Annand (Hemiptera:Adelgidae), affect a non-target soil arthropod community surrounding eastern hemlock, Tsuga canadensis (L.) Carriere. Thesis. University of Tennessee, Knoxville, USA.

Robinson, S. A., S. D. Richardson, R. L. Dalton, F. Maisonneuve, V. L. Trudeau, B. D. Pauli, and S. S. Y. Lee-Jenkins. 2017. Sublethal effects on wood frogs chronically exposed to environmentally relevant concentrations of two neonicotinioid insecticides. Environmental Toxicology and Chemistry 36:1101-1109.

Roff, D. 1993. Evolution of life histories: theory and analysis. Chapman and Hall, New York, New York, USA.

Rollins-Smith, L. A., and D. C. Woodhams. 2012. Amphibian immunity. Oxford University Press, New York, New York, USA.

Ross, R. M., R. M. Bennett, C. D. Snyder, J. A. Young, D. R. Smith, and D. P. Lemarie. 2003. Influence of eastern hemlock (Tsuga canadensis L.) on fish community structure and function in headwater streams of the Delaware River basin. Ecology of Freshwater Fish 12:60-65.

Roznik, E. A., S. J. Sapsford, D. A. Pike, L. Schwarzkopf, and R. A. Alford. 2015. Conditiondependent reproductive effort in frogs infected by a widespread pathogen. Proceedings of the Royal Society B: Biological Sciences 282. 
Ruiz de Arcaute, C., J. M. Pérez-Iglesias, N. Nikoloff, G. S. Natale, S. Soloneski, and M. L. Larramendy. 2014. Genotoxicity evaluation of the insecticide imidacloprid on circulating blood cells of Montevideo tree frog Hypsiboas pulchellus tadpoles (Anura, Hylidae) by comet and micronucleus bioassays. Ecological Indicators 45:632-639.

Schulte-Hostedde, A. I., B. Zinner, J. S. Millar, and G. J. Hickling. 2005. Restitution of masssize residuals: validating body condition indices. Ecology 86:155-163.

Silcox, C. A. 2002. Using imidacloprid to control hemlock woolly adelgid. Pages 280-287 in. Proceedings in hemlock woolly adelgid in the eastern United States. NJ Agricultural Experiment Station, New Brunswick, New Jersey.

Sih, A., A. M. Bell, and J. L. Kerby. 2004. Two stressors are far deadlier than one. Trends in Ecology and Evolution 19:274-276.

Sparling, D. W., G. M. Fellers, and L. L. McConnell. 2001. Pesticides and amphibian population declines in California, USA. Environmental toxicology and chemistry / SETAC 20:1591-5.

Spectrum Technologies. 2008. FieldScout TDR100 Soil Moisture Meter User's Manual. Spectrum Technologies, INC., Plainfield, Illinois, USA.

Strickler, L. K. 2012. Hemlock woolly adelgid control project annual report 2012: New River Gorge National River, Gauley River National Recreation Area, and Bluestone National Scenic River. NPS Natural Resources Report Series. Department of Interior National Park Service. Glen Jean, West Virginia, USA.

Strojny, C. A., and M. L. Hunter Jr. 2009. Log diameter influences detection of eastern redbacked salamanders (Plethodon cinereus) in harvest gaps, but not in closed-canopy forest conditions. Herpetological Conservation and Biology 5:80-85.

Uhl, P., R. Bucher, R. B. Schäfer, and M. H. Entling. 2015. Sublethal effects of imidacloprid on interactions in a tritrophic system of non-target species. Chemosphere 132:152-158.

Van Meter, R. J., D. A. Glinski, W. M. Henderson, A. W. Garrison, M. Cyterski, and S. T. Purucker. 2015. Pesticide uptake across the amphibian dermis through soil and overspray exposures. Archives of Environmental Contamination and Toxicology 69:545-556.

Van Meter, R. J., D. A. Glinski, T. Hong, M. Cyterski, W. M. Henderson, and S. T. Purucker. 2014. Estimating terrestrial amphibian pesticide body burden through dermal exposure. Environmental Pollution 193:262-268.

Vanderhorst, J., J. Jeuck, and S. Gawler. 2007. Vegetation classification and mapping of New River Gorge National River, West Virginia. US Department of the Interior, National Park Service. Northeast Region, Philadelphia, Pennsylvania.

Vanderhorst, J. P., B. P. Streets, Z. Arcaro, and S. C. Gawler. 2010. Vegetation classification and mapping of Gauley River National Recreation Area, West Virginia. US Department of the Interior, National Park Service. Northeast Region, Philadelphia, Pennsylvania.

Welch, B. L. 1947. The generalization of Student's problem when several different population varlances are involved. Biometrika 34:28-35.

Wells, K. D., and R. A. Wells. 1976. Patterns of movement in a population of the slimy salamander, Plethodon glutinosus, with observations on aggregations. Herpetologica 32:156-162.

Welsh Jr, H. H., and S. Droege. 2001. A case for using plethodontid salamanders for monitoring biodiversity and ecosystem integrity of North American forests. Conservation Biology 15:558-569.

West Virginia Department of Natural Resources. 2015. West Virginia State Wildlife Action Plan. Charleston, West Virginia, USA. 
White, C. S. 1986. Volatile and water-soluble inhibitors of nitrogen mineralization and nitrification in a ponderosa pine ecosystem. Biology and Fertility of Soils 2:97-104.

Wood, P. B., J. H. Perez, and J. M. Wood. 2008. Hemlock ecosystem monitoring in southern West Virginia. Pages 270-278 in B. P. Onken and R. C. Reardon, editors. Proceedings of the Fourth Symposium on Hemlock Woolly Adelgid in the Eastern United States. USDA Forest Service, Forest Health Technology Enterprise Team, Hartford, Connecticut, USA.

Wyman, R. L. 1998. Experimental assessment of salamanders as predators of detrital food webs: effects on invertebrates, decomposition and the carbon cycle. Biodiversity and Conservation 7:641-650.

Yamasaki, M., R. M. DeGraaf, and J. W. Lanier. 1999. Wildlife habitat associations in eastern hemlock-birds, smaller mammals, and forest carnivores. Pages 135-143 in K. A. McManus, K. S. Shields, and D. R. Souto, editors. Proceedings: Symposium on Sustainable Management of Hemlock Ecosystems in Eastern North America. Netown Square, Pennsylvania, USA.

Zuur, A. F., E. N. Leno, and C. S. Elphick. 2010. A protocol for data exploration to avoid common statistical problems. Methods in Ecology and Evolution 1:3-14. 
Table 2-1. Total detections and captures-per-unit effort (CPUE) of each salamander species captured in terrestrial plots located in eastern hemlock (Tsuga canadensis) forests that have been treated or not been treated with imidacloprid. Plots were located in Gauley River National Recreation Area and New River Gorge National River, West Virginia, USA. For each species and life stage, CPUE was calculated by dividing total detections by the total number of surveys per plot, and then averaging across plots. Standard deviation (SD) is displayed next to CPUE. Species are ordered from the highest number of detections to the lowest. Plethodon cinereus and Plethodon glutinosis were separated by adults and juveniles for further analysis, while the other species were not separated into age classes or analyzed due to low detections.

\begin{tabular}{lccccc}
\multirow{2}{*}{ Species } & Total & \multicolumn{2}{c}{ Control } & \multicolumn{2}{c}{ Treatment } \\
Detections & Detections & CPUE \pm SD & Detections & CPUE \pm SD \\
\hline Plethodon cinereus & 787 & 393 & $1.49 \pm 1.35$ & 394 & $1.50 \pm 1.36$ \\
$\quad$ Adults & 644 & 321 & $1.22 \pm 1.14$ & 323 & $1.23 \pm 1.14$ \\
$\quad$ Juveniles & 143 & 72 & $0.27 \pm 0.30$ & 71 & $0.27 \pm 0.25$ \\
Plethodon glutinosis & 77 & 35 & $0.13 \pm 0.17$ & 42 & $0.16 \pm 0.28$ \\
$\quad$ Adults & 41 & 21 & $0.08 \pm 0.12$ & 20 & $0.08 \pm 0.22$ \\
$\quad$ Juveniles & 36 & 14 & $0.05 \pm 0.08$ & 22 & $0.09 \pm 0.14$ \\
Notophthalmus v. viridescens & 23 & 13 & $0.05 \pm 0.10$ & 10 & $0.04 \pm 0.09$ \\
Eurycea cirrigera & 16 & 10 & $0.04 \pm 0.09$ & 6 & $0.02 \pm 0.05$ \\
Hemidactylium scutatum & 5 & 3 & $0.01 \pm 0.04$ & 2 & $0.01 \pm 0.02$ \\
Desmognathus fuscus & 4 & 1 & $0.00 \pm 0.02$ & 3 & $0.01 \pm 0.04$ \\
Desmognathus ochrophaeus & 3 & 1 & $0.00 \pm 0.01$ & 2 & $0.01 \pm 0.04$ \\
Desmognathus monticola & 2 & 0 & $0.00 \pm 0.00$ & 2 & $0.01 \pm 0.04$ \\
Pseudotriton r. ruber & 2 & 1 & $0.00 \pm 0.02$ & 1 & $0.00 \pm 0.02$ \\
Ambystoma maculatum & 1 & 0 & $0.00 \pm 0.00$ & 1 & $0.00 \pm 0.02$ \\
\hline
\end{tabular}


Table 2-2. Imidacloprid (IMI) concentrations in soil samples extracted from terrestrial salamander plots located in eastern hemlock (Tsuga canadensis) forests that have been treated (Tx) or not treated with imidacloprid. Plots were located in Gauley River National Recreation Area and New River Gorge National River, West Virginia, USA. Dashes represent samples in which no imidacloprid or metabolites were detected. Site codes that end in "T" indicate a treatment site, while codes ending in " $\mathrm{C}$ " indicate control sites.

\begin{tabular}{|c|c|c|c|c|c|c|c|c|c|}
\hline \multirow[b]{2}{*}{$\begin{array}{l}\text { Site } \\
\text { Code }\end{array}$} & \multicolumn{4}{|c|}{ Concentrations (ng/g dry weight) } & \multirow[b]{2}{*}{$\begin{array}{c}\text { Number } \\
\text { of Tx } \\
\text { Trees }\end{array}$} & \multirow{2}{*}{$\begin{array}{c}\text { Total } \\
\text { Tx } \\
\text { Tree } \\
\text { DBH }\end{array}$} & \multicolumn{3}{|c|}{ Mean Years Since $T x$} \\
\hline & $\begin{array}{c}\text { IMI } \\
\text { Olefin }\end{array}$ & $\begin{array}{c}\text { IMI } \\
\text { Urea }\end{array}$ & IMI & $\begin{array}{c}\text { Surrogate } \\
\text { Recovery } \\
(\%)\end{array}$ & & & 2017 & 2018 & 2019 \\
\hline BBC & - & - & - & 47 & & & & & \\
\hline BBT & - & - & 6.55 & 50 & 5 & 96.0 & - & 5.40 & 6.40 \\
\hline BW1C & - & - & - & 41 & & & & & \\
\hline BW1T & - & - & - & 41 & 5 & 149.9 & 5.00 & 6.00 & 7.00 \\
\hline $\mathrm{BW} 2 \mathrm{C}$ & - & - & - & 34 & & & & & \\
\hline BW2T & - & - & - & 39 & 0 & 0.0 & & & \\
\hline $\mathrm{CFC}$ & - & - & - & 70 & & & & & \\
\hline CFT & - & - & 6.48 & 32 & 11 & 243.1 & - & 2.00 & 3.00 \\
\hline ECC & - & - & - & 35 & & & & & \\
\hline ECT & - & - & 20.88 & 45 & 3 & 103.6 & - & 4.00 & 5.00 \\
\hline FBC & - & - & - & 44 & & & & & \\
\hline FBT & - & - & - & 72 & 3 & 102.4 & - & 2.00 & 3.00 \\
\hline FC1C & - & - & - & 48 & & & & & \\
\hline $\mathrm{FC} 1 \mathrm{~T}$ & 1.82 & - & 28.52 & 39 & 7 & 247.4 & 5.57 & 6.57 & 7.57 \\
\hline $\mathrm{FC} 2 \mathrm{C}$ & - & - & - & 52 & & & & & \\
\hline $\mathrm{FC} 2 \mathrm{~T}$ & - & - & 24.58 & 30 & 16 & 586.2 & 6.12 & 7.12 & 8.12 \\
\hline FC4C & - & - & - & 50 & & & & & \\
\hline $\mathrm{FC} 4 \mathrm{~T}$ & - & - & - & 47 & 8 & 319.5 & - & 7.43 & 8.43 \\
\hline KM1C & - & - & - & 64 & & & & & \\
\hline KM1T & - & - & 0.87 & 50 & 8 & 256.0 & 5.50 & 6.50 & 7.50 \\
\hline $\mathrm{KM} 2 \mathrm{C}$ & - & - & - & 43 & & & & & \\
\hline KM2T & - & - & - & 51 & 2 & 67.3 & - & 2.00 & 3.00 \\
\hline NTC & - & - & - & 55 & & & & & \\
\hline NTT & - & - & - & 53 & 4 & 168.3 & - & 5.00 & 6.00 \\
\hline PB1C & - & - & - & 35 & & & & & \\
\hline PB1T & - & - & - & 48 & 4 & 93.8 & 1.00 & 2.00 & 3.00 \\
\hline PB2C & - & - & - & 42 & & & & & \\
\hline PB2T & 2.63 & 3.98 & 216.53 & 35 & 7 & 186.0 & 1.00 & 2.00 & 3.00 \\
\hline $\mathrm{RCC}$ & - & - & - & 43 & & & & & \\
\hline RCT & - & - & 2.04 & 40 & 6 & 189.2 & 2.67 & 3.67 & 4.67 \\
\hline SD1C & - & - & - & 29 & & & & & \\
\hline SD1T & - & - & 4.36 & 41 & 8 & 373.2 & 3.00 & 4.00 & 5.00 \\
\hline $\mathrm{SD} 2 \mathrm{C}$ & - & - & - & 34 & & & & & \\
\hline SD2T & - & - & 0.64 & 55 & 0 & 0.0 & & & \\
\hline WFC & - & - & - & 61 & & & & & \\
\hline WFT & - & - & 0.53 & 59 & 7 & 193.0 & 3.00 & 4.00 & 5.00 \\
\hline
\end{tabular}


Table 2-3. Control and treatment plot model selection results for the influence of environmental variables on terrestrial salamander captures-per-unit-effort (CPUE) in eastern hemlock (Tsuga canadensis) forests in Gauley River National Recreation Area and New River Gorge National River, West Virginia, USA. Sample groups consisted of adult Plethodon cinereus (Adult PLCI; $\mathrm{n}=542$ ), adult $P$. glutinosis and $P$. cinereus (Total Adults; $\mathrm{n}=577$ ), and juvenile $P$. glutinosis and $P$. cinereus (Total Juveniles; $\mathrm{n}=151$ ). Environmental variables were standardized prior to analyses and included canopy cover (\%; canopy), soil $\mathrm{pH}$ (converted to $\mathrm{H}^{+}$), soil moisture (\% volumetric water content), mean cover objects searched across all samples (cover objects), total tree diameter at breast height (total DBH), and combined duff and litter depth (cm; duff and litter depth). The intercept-only model is represented by ( . ). We ranked each candidate predictor using Akaike's Information Criterion corrected for small sample size $(\triangle \mathrm{AIC} c)$ and included additive and interaction candidate models in the model selection for the two most supported predictors.

\begin{tabular}{|c|c|c|c|c|}
\hline Model & Parameters & $\mathrm{AICc}$ & $\Delta \mathrm{AIC} c$ & $w_{i}$ \\
\hline \multicolumn{5}{|l|}{ Adult PLCI $(n=644)$} \\
\hline Canopy x Cover Objects & 6 & 287.10 & 0.00 & 0.98 \\
\hline Canopy & 4 & 296.81 & 9.71 & 0.01 \\
\hline Canopy + Cover Objects & 5 & 297.52 & 10.43 & 0.01 \\
\hline Cover Objects & 4 & 300.12 & 13.02 & 0.00 \\
\hline ( . ) & 3 & 300.40 & 13.30 & 0.00 \\
\hline Soil Moisture & 4 & 301.39 & 14.30 & 0.00 \\
\hline Soil pH & 4 & 302.28 & 15.19 & 0.00 \\
\hline Duff and Litter Depth & 4 & 302.48 & 15.38 & 0.00 \\
\hline Total DBH & 4 & 302.55 & 15.45 & 0.00 \\
\hline \multicolumn{5}{|l|}{ Total Adults $(\mathrm{n}=685)$} \\
\hline Canopy x Cover Objects & 6 & 289.00 & 0.00 & 1.00 \\
\hline Canopy + Cover Objects & 5 & 305.14 & 16.14 & 0.00 \\
\hline Canopy & 4 & 306.26 & 17.27 & 0.00 \\
\hline Cover Objects & 4 & 308.47 & 19.47 & 0.00 \\
\hline$()$. & 3 & 310.93 & 21.93 & 0.00 \\
\hline Soil Moisture & 4 & 311.76 & 22.76 & 0.00 \\
\hline Soil pH & 4 & 312.83 & 23.83 & 0.00 \\
\hline Duff and Litter Depth & 4 & 313.01 & 24.01 & 0.00 \\
\hline Total DBH & 4 & 313.12 & 24.12 & 0.00 \\
\hline \multicolumn{5}{|l|}{ Total Juveniles $(n=179)$} \\
\hline Canopy & 4 & 81.27 & 0.00 & 0.39 \\
\hline Canopy + Soil Moisture & 5 & 83.06 & 1.79 & 0.16 \\
\hline Canopy x Soil Moisture & 6 & 83.83 & 2.57 & 0.11 \\
\hline$()$. & 3 & 83.96 & 2.69 & 0.10 \\
\hline Soil Moisture & 4 & 84.51 & 3.24 & 0.08 \\
\hline Soil pH & 4 & 85.54 & 4.27 & 0.05 \\
\hline Cover Objects & 4 & 85.94 & 4.68 & 0.04 \\
\hline Total DBH & 4 & 86.08 & 4.81 & 0.04 \\
\hline Duff and Litter Depth & 4 & 86.12 & 4.85 & 0.03 \\
\hline
\end{tabular}


Table 2-4. Control and treatment plot model selection results for the influence of environmental variables on terrestrial salamander body condition index (BCI) scores in eastern hemlock (Tsuga canadensis) forests in Gauley River National Recreation Area and New River Gorge National River, West Virginia, USA. Sample groups consisted of adult Plethodon cinereus (Adult PLCI; $\mathrm{n}$ $=536$ ), adult $P$. glutinosis and $P$. cinereus (Total Adults; $\mathrm{n}=571$ ), and juvenile $P$. glutinosis and $P$. cinereus (Total Juveniles; $\mathrm{n}=149$ ). Environmental variables were standardized prior to analyses and included canopy cover (\%; canopy), soil $\mathrm{pH}\left(\right.$ converted to $\mathrm{H}^{+}$), soil moisture (\% volumetric water content), mean cover objects searched across all samples (cover objects), total tree diameter at breast height (total DBH), and combined duff and litter depth $(\mathrm{cm}$; duff and litter depth). The intercept-only model is represented by $($.$) . We ranked each candidate predictor$ using Akaike's Information Criterion corrected for small sample size $(\triangle \mathrm{AIC} c)$ and included additive and interaction candidate models in the model selection for the two most supported predictors.

\begin{tabular}{lccccc}
\hline Model & Parameters & AIC $\boldsymbol{c}$ & $\mathbf{\Delta A I C} \boldsymbol{c}$ & $\boldsymbol{w}_{\boldsymbol{i}}$ \\
\hline Adult PLCI (n = 644) & & & & \\
Total DBH x Cover Objects & 5 & 1785.13 & 0.00 & 0.68 \\
Total DBH + Cover Objects & 4 & 1786.76 & 1.63 & 0.30 \\
Cover Objects & 3 & 1794.78 & 9.64 & 0.00 \\
Total DBH & 3 & 1806.82 & 21.68 & 0.00 \\
(.) & 2 & 1807.90 & 22.77 & 0.00 \\
Canopy & 3 & 1808.67 & 23.54 & 0.00 \\
Soil Moisture & 3 & 1809.22 & 24.08 & 0.00 \\
Soil pH & 3 & 1809.36 & 24.23 & 0.00 \\
Duff and Litter Depth & 3 & 1809.75 & 24.62 & 0.00 \\
& & & & \\
Total Adults (n= 685) & & & & \\
Total DBH x Cover Objects & 5 & 1905.65 & 0.00 & 0.51 \\
Total DBH + Cover Objects & 4 & 1905.81 & 0.15 & 0.47 \\
Cover Objects & 3 & 1913.31 & 7.65 & 0.01 \\
Total DBH & 3 & 1921.98 & 16.33 & 0.00 \\
(.) & 2 & 1923.25 & 17.59 & 0.00 \\
Canopy Cover & 3 & 1923.30 & 17.65 & 0.00 \\
Soil Moisture & 3 & 1924.43 & 18.77 & 0.00 \\
Soil pH & 3 & 1924.77 & 19.11 & 0.00 \\
Duff and Litter Depth & 3 & 1925.24 & 19.58 & 0.00 \\
Total Juveniles (n = 179) & & & & \\
(.) & & & & \\
Cover Objects & 2 & 501.52 & 0.00 & 0.23 \\
Total DBH & 3 & 502.56 & 1.03 & 0.13 \\
Canopy & 3 & 502.95 & 1.43 & 0.11 \\
Cover Objects + Total DBH & 3 & 503.03 & 1.50 & 0.10 \\
Soil Moisture & 4 & 503.21 & 1.68 & 0.09 \\
Duff and Litter Depth & 3 & 503.40 & 1.87 & 0.09 \\
Soil pH & 3 & 503.45 & 1.93 & 0.08 \\
Cover Objects x Total DBH & 3 & 503.57 & 2.04 & 0.08 \\
\hline & 5 & 504.80 & 3.28 & 0.04 \\
\hline
\end{tabular}


Table 2-5. Control and treatment plot model selection results for the influence of imidacloprid variables on terrestrial salamander captures-per-unit-effort (CPUE) and body condition index (BCI) scores in eastern hemlock (Tsuga canadensis) forests in Gauley River National Recreation Area and New River Gorge National River, West Virginia, USA. Sample groups consisted of adult Plethodon cinereus (Adult PLCI), adult $P$. glutinosis and P. cinereus (Total Adults), and juvenile $P$. glutinosis and $P$. cinereus (Total Juveniles). Imidacloprid variables included total treated tree diameter at breast height (Tx Tree DBH) standardized before analysis and treatment presence (a categorical variable representing whether the site was located in a treated or nontreated area; Tx Presence). The intercept-only model is in parentheses and included top environmental predictors from the first stage of the model selection process (Table 2-3 and 2-4). We ranked each imidacloprid predictor using Akaike's Information Criterion corrected for small sample size $(\triangle \mathrm{AIC} c)$.

\begin{tabular}{|c|c|c|c|c|}
\hline Model & Parameters & $\mathrm{AICc}$ & $\Delta \mathrm{AIC} c$ & $w_{i}$ \\
\hline \multicolumn{5}{|l|}{ Adult PLCI } \\
\hline \multicolumn{5}{|l|}{$\overline{\operatorname{CPUE~}(n=644)}$} \\
\hline (Canopy x Cover Objects) + Tx Tree DBH & 6 & 161.49 & 0.00 & 1.00 \\
\hline (Canopy x Cover Objects) & 7 & 287.10 & 125.60 & 0.00 \\
\hline (Canopy x Cover Objects) + Tx Presence & 7 & 288.56 & 127.07 & 0.00 \\
\hline \multicolumn{5}{|l|}{ BCI $(n=636)$} \\
\hline (Total DBH x Cover Objects) & 5 & 1785.13 & 0.00 & 0.43 \\
\hline (Total DBH x Cover Objects) + Tx Presence & 6 & 1785.34 & 0.20 & 0.39 \\
\hline (Total DBH x Cover Objects) + Tx Tree DBH & 6 & 1786.80 & 1.66 & 0.19 \\
\hline \multicolumn{5}{|l|}{ Total Adults } \\
\hline \multicolumn{5}{|l|}{$\operatorname{CPUE~}(n=685)$} \\
\hline (Canopy x Cover Objects) + Tx Tree DBH & 7 & 160.76 & 0.00 & 1.00 \\
\hline (Canopy x Cover Objects) & 6 & 289.00 & 128.24 & 0.00 \\
\hline (Canopy x Cover Objects) + Tx Presence & 7 & 290.35 & 129.59 & 0.00 \\
\hline \multicolumn{5}{|l|}{ BCI $(n=677)$} \\
\hline (Total DBH x Cover Objects) & 5 & 1905.66 & 0.00 & 0.47 \\
\hline (Total DBH x Cover Objects) + Tx Presence & 6 & 1906.22 & 0.56 & 0.35 \\
\hline (Total DBH x Cover Objects) + Tx Tree DBH & 6 & 1907.56 & 1.90 & 0.18 \\
\hline \multicolumn{5}{|l|}{ Total Juveniles } \\
\hline \multicolumn{5}{|l|}{$\overline{\mathrm{CPUE}(\mathrm{n}=179)}$} \\
\hline$($ Canopy $)+$ Tx Tree DBH & 5 & 48.86 & 0.00 & 1.00 \\
\hline (Canopy) & 4 & 81.27 & 32.41 & 0.00 \\
\hline (Canopy) + Tx Presence & 5 & 83.27 & 34.41 & 0.00 \\
\hline \multicolumn{5}{|l|}{ BCI $(n=176)$} \\
\hline$()$. & 2 & 501.52 & 0.00 & 0.56 \\
\hline Tx Tree DBH & 3 & 503.33 & 1.81 & 0.23 \\
\hline Tx Presence & 3 & 503.48 & 1.95 & 0.21 \\
\hline
\end{tabular}


Table 2-6. Model coefficient ( $\beta$ ) estimates and $85 \%$ confidence intervals (CI) for supported control and treatment plot models investigating potential sublethal effects of imidacloprid on salamander captures-per-unit-effort (CPUE) and body condition index (BCI) scores in eastern hemlock (Tsuga canadensis) forests in Gauley River National Recreation Area and New River Gorge National River, West Virginia, USA. Sample groups consisted of adult Plethodon cinereus (Adult PLCI), adult $P$. glutinosis and $P$. cinereus (Total Adults), and juvenile $P$. glutinosis and $P$. cinereus (Total Juveniles). Imidacloprid variables were standardized prior to analyses and included total treated tree diameter at breast height (Tx Tree DBH) and treatment presence (a categorical variable representing whether the site was located in a treated or nontreated area; Tx Presence). Imidacloprid predictors defined in the table represent imidacloprid variables with Akaike's Information Criterion corrected for small sample size ( $\triangle \mathrm{AIC} c)$ scores of less than 2.

\begin{tabular}{|c|c|c|c|}
\hline Variables & $\boldsymbol{\beta}$ & SE & $85 \% \mathrm{CI}$ \\
\hline \multicolumn{4}{|l|}{ Adult PLCI } \\
\hline \multicolumn{4}{|l|}{ CPUE $(n=644)$} \\
\hline \multicolumn{4}{|c|}{$($ Canopy $x$ Cover Objects $)+T x$ Tree DBH } \\
\hline Intercept & 1.36 & 0.26 & $0.98-1.74$ \\
\hline Canopy & -0.16 & 0.61 & $-1.11-0.73$ \\
\hline Cover Objects & 0.43 & 0.22 & $0.07-0.76$ \\
\hline Canopy x Cover Objects & -0.89 & 0.38 & $-1.46--0.34$ \\
\hline Tx Tree DBH & 0.31 & 0.35 & $-0.19-0.86$ \\
\hline \multicolumn{4}{|l|}{ BCI $(n=636)$} \\
\hline \multicolumn{4}{|c|}{$($ Total DBH $x$ Cover Objects $)+T x$ Presence } \\
\hline Intercept & 0.08 & 0.06 & $0.00-0.16$ \\
\hline Total DBH & 0.15 & 0.04 & $0.09-0.21$ \\
\hline Cover Objects & -0.17 & 0.05 & $-0.23--0.10$ \\
\hline Total DBH x Cover Objects & -0.05 & 0.05 & $-0.12-0.02$ \\
\hline Tx Presence & -0.13 & 0.09 & $-0.26-0.01$ \\
\hline \multicolumn{4}{|c|}{$($ Total DBH $x$ Cover Objects $)+T x$ Tree DBH } \\
\hline Intercept & 0.02 & 0.04 & $-0.04-0.08$ \\
\hline Total DBH & 0.14 & 0.04 & $0.08-0.20$ \\
\hline Cover Objects & -0.16 & 0.04 & $-0.22--0.09$ \\
\hline Total DBH x Cover Objects & -0.08 & 0.05 & $-0.14--0.01$ \\
\hline Tx Tree DBH & -0.03 & 0.04 & $-0.09-0.03$ \\
\hline
\end{tabular}

\section{Total Adults}

CPUE (n = 685)

(Canopy x Cover Objects) + Tx Tree DBH

Intercept

$\begin{array}{lll}1.45 & 0.27 & 1.06-1.85\end{array}$

Canopy

$\begin{array}{lll}-0.38 & 0.63 & -1.34-0.54\end{array}$

Cover Objects

$\begin{array}{lll}0.54 & 0.22 & 0.19-0.88\end{array}$

Canopy x Cover Objects

$-1.19 \quad 0.38 \quad-1.76--0.63$

Tx Tree DBH

$\begin{array}{lll}0.40 & 0.36 & -0.12-0.95\end{array}$


Table 2-6. (continued)

\begin{tabular}{|c|c|c|c|}
\hline Variables & $\boldsymbol{\beta}$ & SE & $85 \% \mathrm{CI}$ \\
\hline \multicolumn{4}{|l|}{ BCI $(n=677)$} \\
\hline \multicolumn{4}{|c|}{ (Total DBH $x$ Cover Objects) + Tx Tree Presence } \\
\hline Intercept & 0.07 & 0.06 & $-0.01-0.15$ \\
\hline Total DBH & 0.14 & 0.04 & $0.08-0.20$ \\
\hline Cover Objects & -0.15 & 0.04 & $-0.22--0.09$ \\
\hline Total DBH x Cover Objects & -0.03 & 0.05 & $-0.11-0.04$ \\
\hline Tx Presence & -0.11 & 0.09 & $-0.25-0.02$ \\
\hline \multicolumn{4}{|c|}{ (Total DBH x Cover Objects) + Tx Tree DBH } \\
\hline Intercept & 0.02 & 0.04 & $-0.04-0.08$ \\
\hline Total DBH & 0.12 & 0.04 & $0.07-0.18$ \\
\hline Cover Objects & -0.14 & 0.04 & $-0.21--0.08$ \\
\hline Total DBH x Cover Objects & -0.06 & 0.05 & $-0.12-0.00$ \\
\hline Tx Tree DBH & -0.01 & 0.04 & $-0.07-0.04$ \\
\hline \multicolumn{4}{|l|}{ Total Juveniles } \\
\hline \multicolumn{4}{|l|}{$\overline{\text { CPUE }(n=179)}$} \\
\hline \multicolumn{4}{|l|}{$($ Canopy $)+T x$ Tree DBH } \\
\hline Intercept & 0.36 & 0.07 & $0.25-0.46$ \\
\hline Canopy & -0.03 & 0.15 & $-0.26-0.20$ \\
\hline Tx Tree DBH & 0.11 & 0.08 & $-0.01-0.23$ \\
\hline \multicolumn{4}{|l|}{$\operatorname{BCI}(n=176)$} \\
\hline \multicolumn{4}{|l|}{ (. ) + Tx Tree $D B H$} \\
\hline Intercept & 0.00 & 0.08 & $-0.11-0.11$ \\
\hline Tx Tree DBH & -0.04 & 0.08 & $-0.15-0.07$ \\
\hline \multicolumn{4}{|l|}{ (. ) + Tx Presence } \\
\hline Intercept & -0.03 & 0.11 & $-0.18-0.13$ \\
\hline Tx Presence & 0.05 & 0.15 & $-0.17-0.27$ \\
\hline
\end{tabular}


Table 2-7. Total detections and mean body condition index (BCI) of Plethodon cinereus and $P$. glutinosis individuals captured over 516 terrestrial salamander surveys conducted to investigate potential sublethal effects of imidacloprid on salamanders in West Virginia, USA.

\begin{tabular}{lccccc}
\multirow{2}{*}{ Species } & \multirow{2}{*}{ Age Class } & \multicolumn{2}{c}{ Total Detections } & \multicolumn{2}{c}{ Mean BCI } \\
& Control & Treatment & Control & Treatment \\
\hline \multirow{2}{*}{ Plethodon cinereus } & Adult & 321 & 323 & $0.01 \pm 0.13$ & $-0.01 \pm 0.15$ \\
& Juvenile & 72 & 71 & $0.01 \pm 0.26$ & $-0.01 \pm 0.26$ \\
& & & & & \\
Plethodon glutinosis & Adult & 21 & 20 & $-0.02 \pm 0.12$ & $0.02 \pm 0.16$ \\
& Juvenile & 14 & 22 & $-0.12 \pm 0.27$ & $0.08 \pm 0.32$ \\
Total Adults & - & 500 & 415 & $0.01 \pm 0.13$ & $-0.01 \pm 0.15$ \\
Total Juveniles & - & 86 & 93 & $-0.01 \pm 0.27$ & $0.01 \pm 0.28$ \\
\hline
\end{tabular}


Table 2-8. Treatment plots-only model selection results to determine the potential effects of imidacloprid on salamander captures-per-unit-effort (CPUE) and body condition index (BCI) scores in eastern hemlock (Tsuga canadensis) forests in Gauley River National Recreation Area and New River Gorge National River, West Virginia, USA. Sample groups consisted of adult Plethodon cinereus (Adult PLCI), adult $P$. glutinosis and $P$. cinereus (Total Adults), and juvenile $P$. glutinosis and $P$. cinereus (Total Juveniles). Imidacloprid variables were standardized and included mean years since treatment (YST) and total treated tree diameter at breast height (Tx Tree DBH). Total treated tree DBH and YST were tested together as both an additive (+) and interaction (x) effect. The intercept-only model is in parentheses and included top environmental predictors (Table 2-3 and 2-4). We ranked each candidate predictor using Akaike's Information Criterion corrected for small sample size $(\triangle \mathrm{AIC} c)$.

\begin{tabular}{|c|c|c|c|c|}
\hline Model & Parameters & $\mathrm{AICc}$ & $\Delta \mathrm{AIC} c$ & $w_{i}$ \\
\hline \multicolumn{5}{|l|}{ Adult PLCI } \\
\hline \multicolumn{5}{|l|}{ CPUE $(n=323)$} \\
\hline (Canopy x Cover Objects) + YST & 7 & 150.55 & 0.00 & 0.77 \\
\hline (Canopy x Cover Objects) + YST + Tx Tree DBH & 8 & 153.65 & 3.10 & 0.16 \\
\hline (Canopy x Cover Objects) + YST x Tx Tree DBH & 9 & 155.58 & 5.03 & 0.06 \\
\hline (Canopy x Cover Objects) & 6 & 159.47 & 8.92 & 0.01 \\
\hline \multicolumn{5}{|l|}{ BCI $(\mathbf{n}=320)$} \\
\hline (Total DBH x Cover Objects) + YST x Tx Tree DBH & 8 & 831.86 & 0.00 & 0.70 \\
\hline (Total DBH x Cover Objects) + YST & 6 & 834.15 & 2.29 & 0.22 \\
\hline (Total DBH x Cover Objects) + YST + Tx Tree DBH & 7 & 836.23 & 4.37 & 0.08 \\
\hline (Total DBH x Cover Objects) & 5 & 848.90 & 17.04 & 0.00 \\
\hline \multicolumn{5}{|l|}{ Total Adults } \\
\hline \multicolumn{5}{|l|}{ CPUE $(n=343)$} \\
\hline (Canopy x Cover Objects) + YST & 7 & 149.18 & 0.00 & 0.76 \\
\hline (Canopy x Cover Objects) + YST + Tx Tree DBH & 8 & 152.28 & 3.10 & 0.16 \\
\hline (Canopy x Cover Objects) + YST x Tx Tree DBH & 9 & 153.84 & 4.66 & 0.07 \\
\hline (Canopy x Cover Objects) & 6 & 159.16 & 9.98 & 0.01 \\
\hline \multicolumn{5}{|l|}{ BCI $(n=340)$} \\
\hline (Total DBH x Cover Objects) + YST x Tx Tree DBH & 8 & 885.36 & 0.00 & 0.92 \\
\hline (Total DBH x Cover Objects) + YST & 6 & 890.82 & 5.45 & 0.06 \\
\hline (Total DBH x Cover Objects) + YST + Tx Tree DBH & 7 & 892.78 & 7.42 & 0.02 \\
\hline (Total DBH x Cover Objects) & 5 & 905.78 & 20.42 & 0.00 \\
\hline \multicolumn{5}{|l|}{ Total Juveniles } \\
\hline \multicolumn{5}{|l|}{$\overline{\text { CPUE }(n=93)}$} \\
\hline (Canopy) & 4 & 48.01 & 0 & 0.58 \\
\hline (Canopy) + YST & 5 & 49.56 & 1.55 & 0.27 \\
\hline$($ Canopy $)+$ YST + Tx Tree DBH & 6 & 51.24 & 3.23 & 0.11 \\
\hline (Canopy) + YST x Tx Tree DBH & 7 & 53.29 & 5.28 & 0.04 \\
\hline \multicolumn{5}{|l|}{ BCI $(\mathbf{n}=91)$} \\
\hline (.) & 2 & 243.34 & 0.00 & 0.56 \\
\hline (.) + YST & 3 & 244.72 & 1.38 & 0.28 \\
\hline (. ) + YST + Tx Tree DBH & 4 & 246.48 & 3.14 & 0.12 \\
\hline$()+$. YST $x$ Tx Tree DBH & 5 & 248.72 & 5.38 & 0.04 \\
\hline
\end{tabular}


Table 2-9. Model coefficient ( $\beta$ ) estimates and $85 \%$ confidence intervals (CI) for supported treatment plots-only models in this study investigating potential sublethal effects of imidacloprid on salamander captures-per-unit-effort (CPUE) and body condition index (BCI) scores in eastern hemlock (Tsuga canadensis) forests in Gauley River National Recreation Area and New River Gorge National River, West Virginia, USA. Sample groups consisted of adult Plethodon cinereus (Adult PLCI), adult $P$. glutinosis and $P$. cinereus (Total Adults), and juvenile $P$. glutinosis and $P$. cinereus (Total Juveniles). Imidacloprid variables were standardized prior to analyses and included mean years since treatment (YST), and total treated tree diameter at breast height (Tx Tree DBH). Total treated tree DBH and YST were tested together as both an additive $(+)$ and interaction $(\mathrm{x})$ effect. Imidacloprid predictors defined in the table represent imidacloprid variables with Akaike's Information Criterion corrected for small sample size ( $\triangle \mathrm{AIC} c)$ scores of less than 2.

\begin{tabular}{|c|c|c|c|}
\hline Variables & $\beta$ & SE & $85 \% \mathrm{CI}$ \\
\hline \multicolumn{4}{|l|}{ Adult PLCI } \\
\hline \multicolumn{4}{|l|}{ CPUE $(n=323)$} \\
\hline \multicolumn{4}{|l|}{ (Canopy $x$ Cover Objects) $+Y S T$} \\
\hline Intercept & 1.43 & 0.25 & $1.04-1.79$ \\
\hline Canopy & -0.03 & 0.26 & $-0.44-0.35$ \\
\hline Cover Objects & 0.48 & 0.24 & $0.08-0.85$ \\
\hline Canopy x Cover Objects & -0.52 & 0.22 & $-0.86--0.20$ \\
\hline YST & 0.26 & 0.27 & $-0.13-0.68$ \\
\hline \multicolumn{4}{|l|}{$\operatorname{BCI}(\mathbf{n}=320)$} \\
\hline \multicolumn{4}{|c|}{ (Total DBH $\times$ Cover Objects) + YST $\times$ T $x$ Tree DBH } \\
\hline Intercept & -0.30 & 0.13 & $-0.48--0.11$ \\
\hline Total DBH & 0.50 & 0.11 & $0.34-0.66$ \\
\hline Cover Objects & -0.43 & 0.12 & $-0.6--0.25$ \\
\hline Total DBH x Cover Objects & 0.24 & 0.17 & $0.01-0.48$ \\
\hline YST & 0.36 & 0.10 & $0.22-0.51$ \\
\hline Tx Tree DBH & -0.16 & 0.10 & $-0.31--0.02$ \\
\hline YST x Tx Tree DBH & 0.24 & 0.09 & $0.10-0.37$ \\
\hline \multicolumn{4}{|l|}{ Total Adults } \\
\hline \multicolumn{4}{|l|}{$\overline{\text { CPUE }(n=343)}$} \\
\hline \multicolumn{4}{|l|}{ (Canopy $x$ Cover Objects $)+Y S T$} \\
\hline Intercept & 1.50 & 0.25 & $1.11-1.87$ \\
\hline Canopy & -0.12 & 0.27 & $-0.53-0.27$ \\
\hline Cover Objects & 0.59 & 0.24 & $0.19-0.96$ \\
\hline Canopy x Cover Objects & -0.69 & 0.22 & $-1.03--0.37$ \\
\hline YST & 0.30 & 0.26 & $-0.09-0.71$ \\
\hline \multicolumn{4}{|l|}{$\operatorname{BCI}(n=340)$} \\
\hline \multicolumn{4}{|c|}{$($ Total DBH $\times$ Cover Objects $)+Y S T \times$ Tx Tree DBH } \\
\hline Intercept & -0.29 & 0.13 & $-0.48--0.11$ \\
\hline Total DBH & 0.48 & 0.12 & $0.31-0.65$ \\
\hline Cover Objects & -0.38 & 0.12 & $-0.55--0.21$ \\
\hline Total DBH x Cover Objects & 0.18 & 0.17 & $-0.06-0.43$ \\
\hline YST & 0.36 & 0.10 & $0.22-0.51$ \\
\hline Tx Tree DBH & -0.20 & 0.10 & $-0.35--0.06$ \\
\hline YST x Tx Tree DBH & 0.28 & 0.09 & $0.15-0.41$ \\
\hline
\end{tabular}


Table 2-9 (continued)

\begin{tabular}{lccc}
\hline Variables & $\boldsymbol{\beta}$ & SE & $\mathbf{8 5 \%}$ CI \\
\hline Total Juveniles & & & \\
\hline CPUE (n = 93) & & & \\
(Canopy) + YST & & & \\
$\quad$ Intercept & 0.35 & 0.08 & $0.24-0.47$ \\
$\quad$ Canopy & 0.01 & 0.08 & $-0.11-0.13$ \\
$\quad$ YST & 0.08 & 0.08 & $-0.04-0.20$ \\
(Canopy) + YST+ Tx Tree DBH & & & \\
$\quad$ Intercept & 0.34 & 0.07 & $0.23-0.45$ \\
$\quad$ Canopy & -0.04 & 0.09 & $-0.17-0.10$ \\
$\quad$ YST & 0.05 & 0.08 & $-0.07-0.17$ \\
$\quad$ Tx Tree DBH & 0.11 & 0.10 & $-0.05-0.26$ \\
BCI (n = 91) & & & \\
(.) + YST & & & \\
$\quad$ Intercept & 0.00 & 0.11 & $-0.16-0.16$ \\
$\quad$ YST & -0.09 & 0.11 & $-0.25-0.06$ \\
\hline
\end{tabular}


Table 2-10. Imidacloprid concentrations found in eight adult Plethodon cinereus collected in $2018(n=4)$ and $2019(n=4)$ in treated eastern hemlock (Tsuga canadensis) forests in Gauley River National Recreation Area and New River Gorge National River, West Virginia, USA. Individuals were analyzed separately using liquid chromatography-tandem mass spectrometry for presence of imidacloprid. Surrogate recovery is a measurement of analysis accuracy. A recovery score of $100 \%$ represents an analysis with no error, while percentages less than or more than 100 represent surrogate recovery with some error.

\begin{tabular}{|c|c|c|c|}
\hline \multirow{2}{*}{ Site } & \multicolumn{2}{|c|}{ Concentration (ng/g) } & \multirow{2}{*}{$\begin{array}{l}\text { Surrogate Recovery } \\
(\% \text {; imidacloprid-d })\end{array}$} \\
\hline & Dry Weight & Wet Weight & \\
\hline Fern Creek & 49.43 & 11.85 & 118.30 \\
\hline Fern Creek & 43.43 & 10.08 & 107.60 \\
\hline Fern Creek & 35.27 & 7.44 & 98.30 \\
\hline Fern Creek & 9.13 & 2.26 & 101.90 \\
\hline Richmond Chapel & 30.17 & 6.53 & 101.50 \\
\hline Richmond Chapel & 16.31 & 3.53 & 99.40 \\
\hline Richmond Chapel & 17.74 & 2.98 & 103.90 \\
\hline Summersville Dam & 43.56 & 12.92 & 95.10 \\
\hline
\end{tabular}




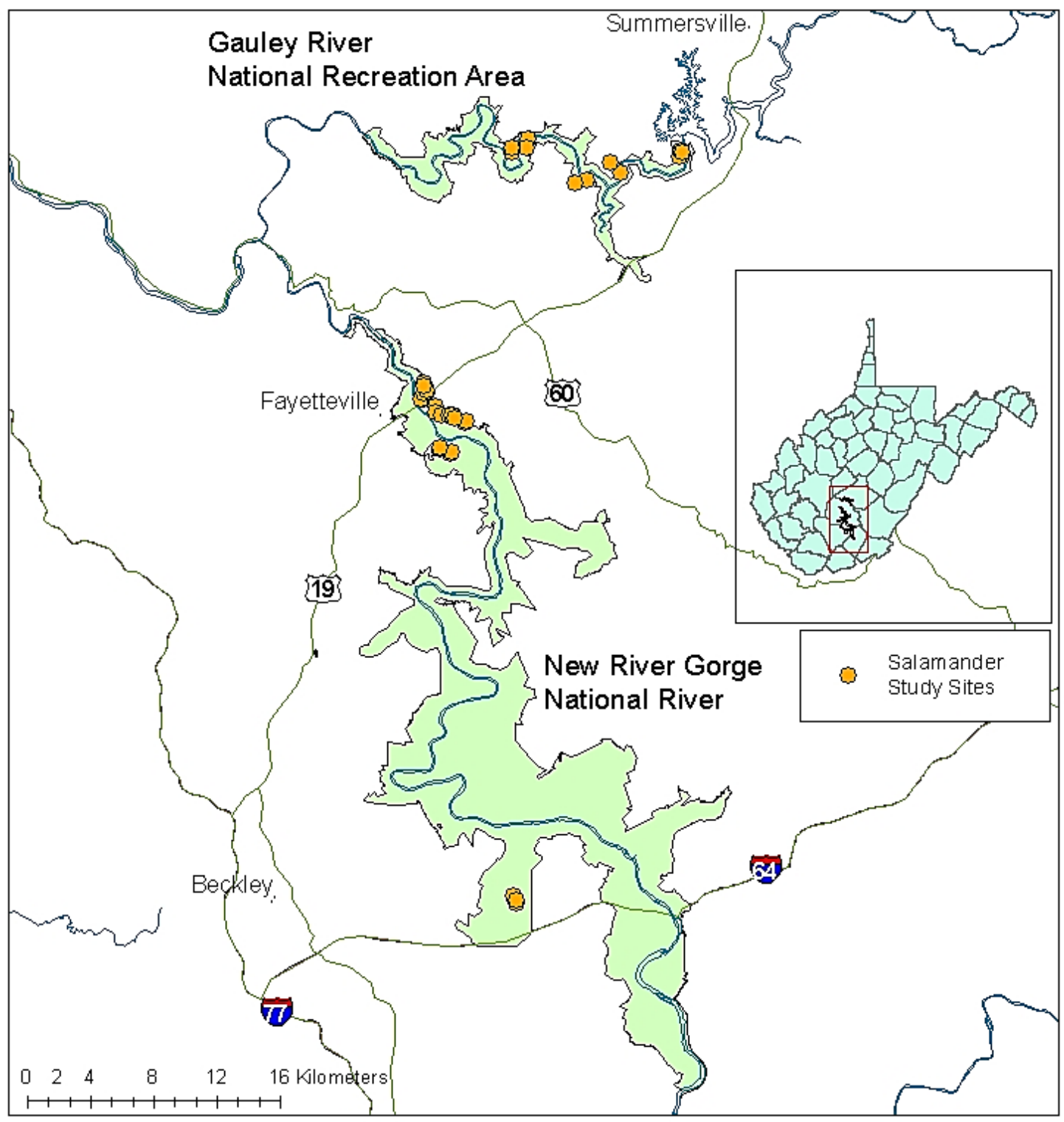

Figure 2-1. Map of imidacloprid study sites used in this study investigating potential effects of imidacloprid on salamander relative abundance and body condition index scores in eastern hemlock (Tsuga canadensis) forests in Gauley River National Recreation Area and New River Gorge National River, West Virginia, USA. There were 18 sites consisting of a treatment plot and a control plot for a total of 36 plots sampled over a three-year period from 2016 to 2019. 


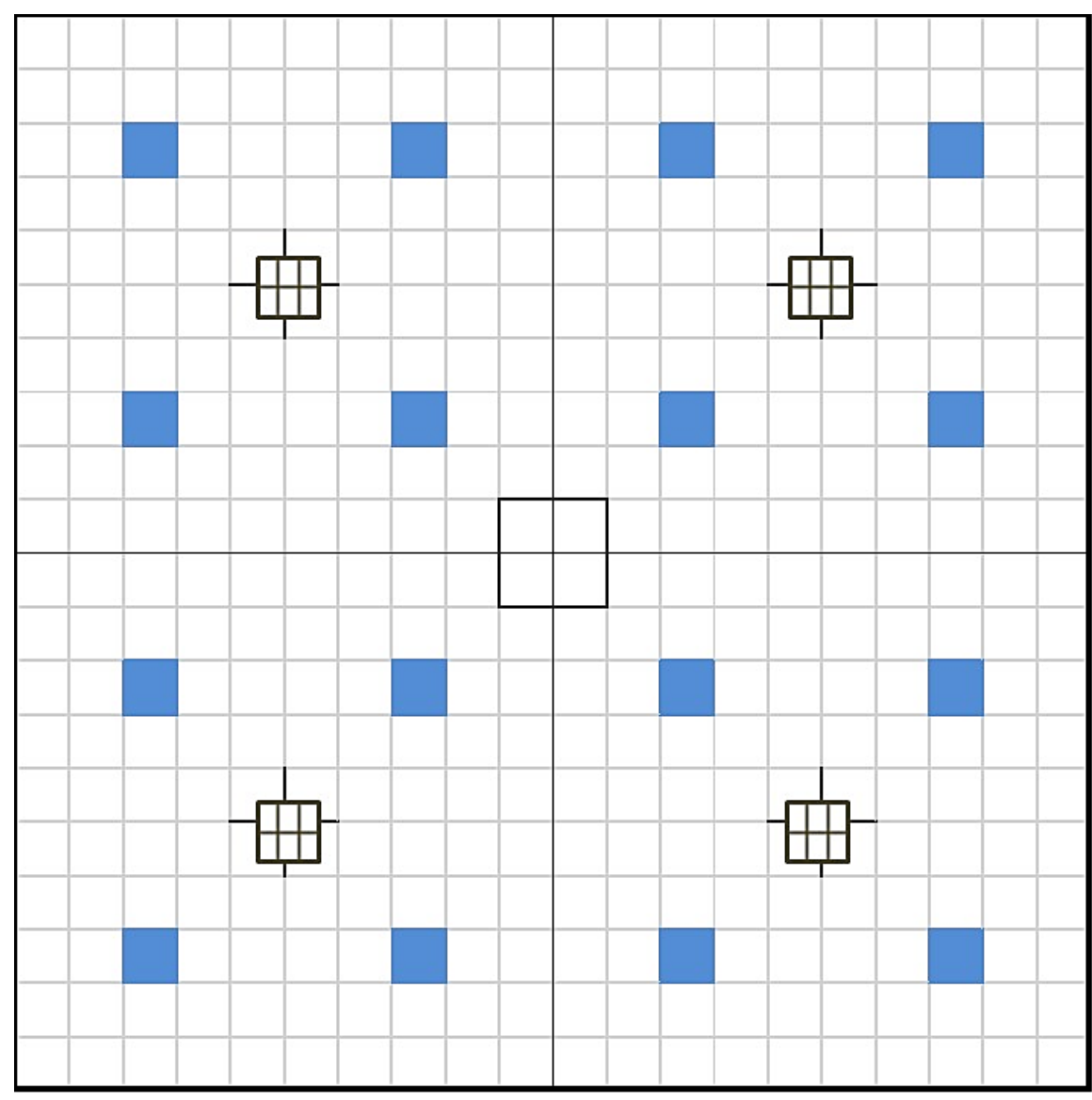

Coverboard grid

Soil sample extraction point

1 sq. meter

Figure 2-2. Terrestrial salamander sampling plot design showing coverboard locations and soil sampling points for imidacloprid quantification during 2017-2019. Plots measured $20 \mathrm{~m}$ x $20 \mathrm{~m}$ and were installed in eastern hemlock (Tsuga canadensis) forest that had been treated or not treated with imidacloprid in Gauley River National Recreation Area and New River Gorge National River, West Virginia, USA. 

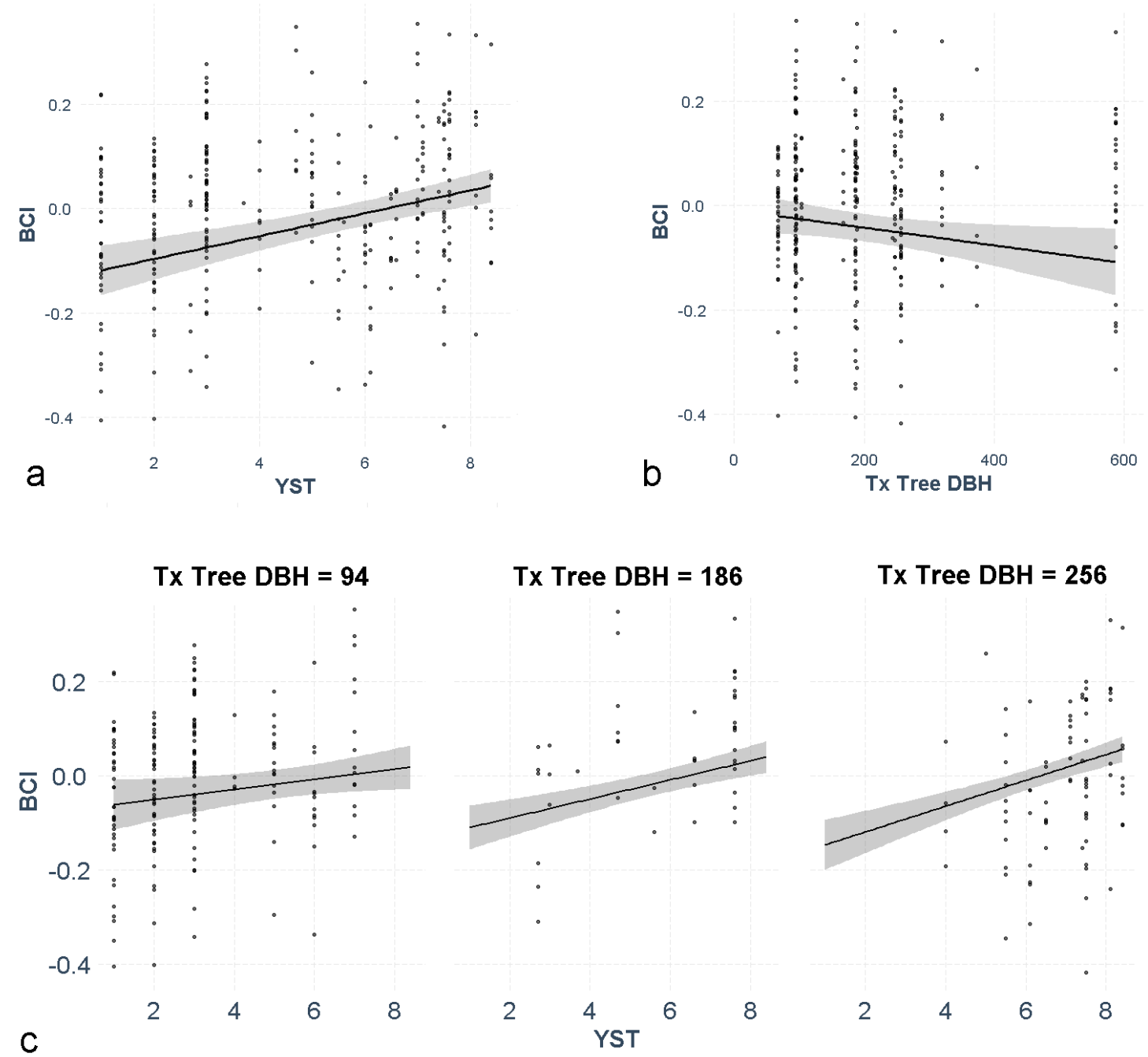

Figure 2-3. Model-estimated relationship showing the effects of years since treatment (YST) and treated tree diameter at breast height (Tx Tree $\mathrm{DBH}$; $\mathrm{cm}$ ) on adult Plethodon cinereus body condition index (BCI) scores in eastern hemlock (Tsuga canadensis) forests treated with imidacloprid in Gauley River National Recreation Area and New River Gorge National Park and Preserve, West Virginia, USA, including: a) estimated relationship between BCI and YST without accounting for Tx Tree DBH; b) estimated relationship between BCI and Tx Tree DBH without accounting for YST; c) estimated relationship between BCI and YST at the mean (186 $\mathrm{cm}$ ) and +/- 1 standard deviation of all plot Tx Tree DBH size (interaction effect). The results indicate that BCI was positively associated with YST and negatively associated with Tx Tree DBH, but plots with greater Tx Tree DBH had a stronger positive influence of YST. Imidacloprid variables were standardized prior to analyses but are displayed in their original units in the figure. 


\section{CHAPTER 3: EFFECT OF IMIDACLOPRID TREATMENTS IN EASTERN HEMLOCK STANDS ON ANT COMMUNITIES}

\section{ABSTRACT}

Imidacloprid is a systemic, neonicotinoid insecticide commonly used to treat eastern hemlock trees (Tsuga canadensis) against damage caused by the invasive insect hemlock woolly adelgid (HWA; Adelges tsugae). We assessed the effects of imidacloprid treatments for HWA on ant communities in two National Park Service (NPS) units that have been treating eastern hemlocks with imidacloprid since 2006. Using bait traps, we sampled ants at 18 control paired with 18 treatment sites, in spring, summer, and fall in 2020. We used linear regression models and a model selection approach to identify important environmental predictors of ant relative abundance and species diversity. We used the most parsimonious environmental model to test the influence of three imidacloprid predictors: treatment presence, total treated tree diameter at breast height (DBH; a proxy for treatment intensity), and years since treatment (YST). We captured a total of 5 species and 17,626 ants, with 10,324 ants captured in control plots and 7,302 in treatment plots. Aphaenogaster picea accounted for $97.5 \%$ of ant captures. The relative abundance of $A$. picea was negatively associated with imidacloprid treatments. Recovery of the species over time was dependent on treated tree $\mathrm{DBH}$, with populations at low and high $\mathrm{DBH}$ sites having a positive and negative response to YST, respectively. Ant diversity was also negatively impacted by imidacloprid treatments, but the effect was weaker, with coefficient confidence intervals overlapping 0 . In addition, we detected imidacloprid in the biomass of ants collected from treatment sites, indicating ants are uptaking the pesticide. 


\section{INTRODUCTION}

In the eastern U.S., a wide assemblage of aquatic and terrestrial biota depend upon unique microclimates generated in eastern hemlock (Tsuga canadensis) forests (Ellison et al. 2005, Sackett et al. 2011, Orwig et al. 2013, Ellison 2014). Eastern hemlock populations are declining due to a nonnative, invasive, aphid-like insect called hemlock woolly adelgid (Adelges tsugae) (McClure 1991, Young et al. 1995, McClure et al. 1996). Hemlock woolly adelgid (HWA) was first detected within the U.S. in Richmond, Virginia in 1951, and is thought to have been introduced from nursery trees shipped from Asia (Gouger 1971). Since its introduction, HWA has spread to ca. $50 \%$ of hemlock forests in the eastern U.S. (Havill et al. 2014). To protect hemlock trees from HWA-induced mortality, federal, state, and private landowners have been treating eastern hemlocks since the mid-1990s with a neonicotinoid insecticide called imidacloprid (Tattar et al. 1998, Silcox 2002, Cowles et al. 2005, 2006, Jeschke and Nauen 2008, Havill et al. 2014). Imidacloprid binds to the nicotine receptors in insect nervous systems, causing impaired mobility, altered behavior, paralysis, and mortality (Reynolds 2008). Imidacloprid can impact non-target arthropods in natural forest systems (reviewed in Sanchez-Bayo et al. 2013). One field-based study investigated the effects of different imidacloprid treatment methods on insects in eastern hemlock forests and found that abundances of predatory insects (insects that consume herbivorous insects) were significantly lower in control plots than plots treated by soil drench, soil injection, and direct tree injection methods (Hakeem 2008). Kreutzweiser et al. (2009) conducted a microcosm study to investigate the effects of fallen leaves from imidacloprid treated trees on leaf-shredding arthropods and observed a sublethal impact to feeding behaviors that led to significant decreases in mass loss of leaf material. They also tested a potential impact avoidance behavior in which decomposer 
invertebrates could distinguish between leaves containing and not containing imidacloprid, but found that the insects were unable to make the distinction. Reynolds (2008) found significant differences in overall soil microarthropod community compositions between control and treatment sites, with control sites having significantly higher collembola abundance compared to soil drench, tree injection, and foliar imidacloprid treatment methods. In another study, Dilling et al. (2009) found that 33 hemlock-associated insect species belonging to the detritivore and phytophagous guilds were significantly affected by imidacloprid treatments. The species most impacted in that study were from the orders Lepidoptera and Psocoptera. Imidacloprid effects on non-target arthropod diversity and/or behavior could have ecosystem level consequences via prey reduction and loss of ecosystem services.

Ants (Hymenoptera: Formicidae) make up 75\% of the world's total insect biomass, provide many vital ecosystem services, and are a primary food source for woodland salamanders (Burton 1976, Pauley 1978, Hölldobler and Wilson 1990, Ivanov et al. 2011, Paluh et al. 2015). Their nesting structures, biology, and movements have extensive effects on the biological, physical, and chemical properties of soil and vegetation (reviewed in Del Toro et al. 2012, 2015). Ant nest structures increase soil porosity (Folgarait 1998, Frouz and Jilková 2008, Del Toro et al. 2015), which has a cascade of effects on micro-organism and macro-invertebrate communities, soil chemistry, and erosion rates (Green et al. 1999, Mody and Linsenmair 2004, Cerdà and Jurgensen 2008). Increased soil porosity causes surface water to drain faster and decreases soil bulk density, which leads to higher aeration rates in soil and lower soil moisture (King 1977, Lockaby and Adams 1985, Nkem et al. 2000, Holec and Frouz 2006, Kilpeläinen et al. 2007). Bioturbation activity by foraging and nest-building ants influences soil nutrient dynamics (Nkem et al. 2000, Frouz et al. 2008, Wardle et al. 2011, Del Toro et al. 2015, Kendrick et al. 2015). For 
example, ants influence soil nutrient concentrations, such as nitrogen, phosphorous, and potassium (Beattie and Culver 1983, Petal 1991, Wagner et al. 2004, Stadler et al. 2006, Kilpeläinen et al. 2007, Wardle et al. 2011, Kendrick et al. 2015). In addition to the impacts on physical and chemical properties of soil, ants also increase local seed dispersal and pollination (reviewed in Del Toro et al. 2012). For woodland salamanders, ants are a primary food source and also increase the availability of critical salamander cover habitat (i.e., leaf litter, coarse woody debris) by slowing decomposition rates in forest plots (Warren and Bradford 2012, Paluh et al. 2015).

Several studies have investigated the impacts of imidacloprid on ants, primarily in pest control settings. Ant population control with imidacloprid requires delayed toxicity in foraging ants, so that the bait can be delivered back to the nest to achieve whole colony control (Rust et al. 2004). Wang et al. (2015a) discovered that imidacloprid exposure in a pest control setting impacted brood tending by queen ants in Solenopsis invicta. In the higher imidacloprid concentration of Wang et al. (2015a), larval emergence was delayed and there were no pupae or worker ants produced. In another study, there was no significant impact to mortality or foraging ability of two study species, but imidacloprid did reduce brood production of invasive Argentine ants (Linepithema humile) by $50 \%$ while not affecting brood production of the native Southern ant (Monomorium antarcticum) (Barbieri et al. 2013). Galvanho et al. (2013) discovered that leafcutter ant (Acromyrmex s. subterraneus) grooming behavior was significantly reduced when exposed to sublethal concentrations of imidacloprid, resulting in greater susceptibility to fungal infections. Multiple studies have shown a decrease in abundance of foraging workers or foraging activity in ants exposed to varying concentrations imidacloprid $(10-1250 \mathrm{ppb}$; Wang et al. 2015b, Thiel and Köhler 2016, Sappington 2018). 
Ants are useful indicators for health of biological systems because they are abundant, geographically widespread, easily sampled, and sensitive to changes in ecological parameters (reviewed in Underwood and Fisher 2006; Andersen 1997, Tiede et al. 2017). While many studies have assessed effects of imidacloprid on specific ant species, the non-target impacts of imidacloprid treatments to ant communities in eastern hemlock forests are not currently known. The goal of this study was to determine whether imidacloprid treatments in hemlock forests are influencing ant abundance and diversity. We hypothesized that the abundance and diversity of ants would be lower in areas with treated trees and would be negatively correlated with the intensity of pesticide applications.

\section{STUDY AREA}

We established 36 research plots in eastern hemlock forests in two NPS units in south-central West Virginia: New River Gorge National Park and Preserve (NERI) and Gauley River National Recreation Area (GARI). This area of West Virginia has a moderate annual average temperature $\left(30\right.$-year mean $\left.=11.1^{\circ} \mathrm{C}\right)$ and high annual precipitation $(30$-year mean $=104.6 \mathrm{~cm}$; National Oceanic and Atmospheric Administration 2016). Elevation in the two units ranges from approximately $244 \mathrm{~m}$ at river level near Gauley Bridge to approximately $853 \mathrm{~m}$ above Slater Creek near the town of Thayer (data accessed via Topoview; https://ngmdb.usgs.gov/topoview). Both units are characterized as steep-sloped river gorges and are located in the Valley and Ridge province of the Appalachian Mountains (National Park Service 2016).

At roughly 29,137 ha, approximately 5\% (1,470 ha) of the total land in NERI is classified as eastern hemlock associated forest (Vanderhorst et al. 2007). Approximately $43 \%$ (2,001 ha) of the 4,654 ha of GARI is classified as eastern hemlock associated forest (Vanderhorst et al. 2010). 
Between 2006 and 2017, hemlock forests in NERI were treated up to 12 times (mean $=4.1$ times, range $=1-12$ times), and had a total of 20,788 treated trees across all years (mean for all sites $=$ 118.8 trees, range $=4-4,004$ trees). Between 2009 and 2017, hemlock forests in GARI were treated up to 5 times (mean $=3.2$ times, range $=1-5$ times), and had a total of 3,448 trees treated across all years (mean for all areas $=690$ trees, range $=214-1,246$ trees).

The 18 site pairs of control and treatment plots established for the woodland salamander portion of this project (Chapter 2) were also used for terrestrial ant community sampling. We used a geographic information system (ArcGIS 10.4, ESRI, Redlands, California) to rank candidate sampling areas based on several factors, including treatment intensity (i.e., total number of treated trees), land ownership, proximity to trails (i.e., accessibility), and distance to sampling sites for concurrent aquatic salamander sampling (Crayton 2019). Within selected areas, plot locations were established by first identifying eastern hemlock stands that had received imidacloprid treatments at least once between 2006 and 2016. Then, a paired control plot containing eastern hemlock and similar understory vegetation was established in the same geographical area of the treatment plot (at least $40 \mathrm{~m}$ away; mean distance $=385 \mathrm{~m}$, range $=40-$ $852 \mathrm{~m})$. The relative position of the control plot to the treatment plot was also taken into consideration. Specifically, the control plot was not established downslope of the treatment plot due to the potential of imidacloprid to flow downslope with groundwater drainage patterns. Sampling plots measured $20 \mathrm{~m} \times 20 \mathrm{~m}$ and were divided into four $10 \mathrm{~m}$ x $10 \mathrm{~m}$ subplots. 


\section{METHODS}

\section{Ant Sampling}

All 18 site pairs were sampled during daylight hours three times between 30 May and 11 September 2019. Individual site pairs were sampled consecutively within the same day to decrease the influence of variation in weather conditions on ant captures between control and treatment sites. We used a standard ant sampling procedure which involved half of a Vienna sausage in a $9 \mathrm{~cm}$ diameter petri dish placed in the center of the coverboards in each subplot (Porter and Tschinkel 1987, Brown et al. 2013). Bait cups were deployed for 30 minutes, collected in individual plastic bags per subplot, and placed on ice for transport. In the laboratory, ant samples were euthanized by freezing, air dried, then identified to species and counted at the subplot level. We used a combination of references to aid in species identification (Holldobler and Wilson 1990, Bolton 1994, Fisher and Cover 2007), and all species determinations were cross-checked by an entomologist at West Virginia University. Eleven of the 432 subplot samples were excluded from the data set due to mold contamination preventing accurate species identification. Three of the contaminated samples were from two separate control plots and 8 were from three separate treatment plots.

\section{Habitat Sampling}

Vegetation surveys. - In summer of 2018, vegetation surveys were conducted in all research plots. All trees $\geq 12.7 \mathrm{~cm}$ diameter at breast height (DBH) were identified to species, counted, and identified as treated or untreated. This DBH size cutoff allowed us to include smaller coniferous and deciduous trees in our total plot DBH. We excluded the numerous clustering 
stems of great rhododendron (Rhododendron maximum), mountain laurel (Kalmia latifolia), and American holly (Ilex opaca) that were frequently $>12.7 \mathrm{~cm}$ in diameter in the plots.

Soil variables. - Soil-related variables were sampled three times per plot, once during each season in 2018 (spring [March 20 - June 21], summer [June 22 - September 22], fall [September 23 - December 22]). We measured soil variables as close to the middle of each season as possible to capture seasonal soil parameter norms. Soil sampling occurred the year prior to ant sampling, and we assumed the prior year data reflected differences among study plots. Microclimatic weather conditions of the immediate surrounding forest strongly influence soil properties, so we expected the variation among plots within a site to be relatively stable from the previous year since there were no major visible changes to the forest structure within any plot (Scharenbroch and Bockheim 2007, Orwig et al. 2008). We measured mineral soil pH at the center of each subplot using an EcoSense pH100A meter with a piercing tip pH electrode (YSI, Yellow Springs, Ohio). A soil slurry was made by stirring a 1:1 ratio of soil and deionized water in cups with pre-measured volumes, which were re-stirred and tested after resting for 15 minutes (Adamchuk et al. 1999). Meters were calibrated each day before going into the field with twopoint calibration. One point of calibration was neutral $\mathrm{pH} 7$, and the second point was a $\mathrm{pH} 4$ buffer due to the acidic nature of hemlock forest soils. Mineral soil volumetric water content (VWC) was measured with a FieldScout TDR100 Soil Moisture Meter (Spectrum Technologies, Aurora, Illinois). If needed, the soil testing area was compressed by hand prior to sampling to minimize air content in the testing area, which can result in inaccurate VWC estimates (Spectrum Technologies 2008). Ten readings were taken at each point to produce an average VWC estimate for each sample. Leaf litter and duff depth was measured $1 \mathrm{~m}$ in front of each coverboard set and rounded to the nearest $0.5 \mathrm{~cm}$. Percent canopy cover was measured at the 
center of each subplot using a convex spherical densiometer (Forestry Suppliers, Jackson, Mississippi) facing toward the plot center and averaged for the plot.

Weather variables. - Weather conditions were recorded for all ant community sampling visits. Ambient air temperature and humidity were recorded at plot center using a Kestrel 3000 weather meter (Kestrel Instruments, Boothwyn, Pennsylvania). Cloud cover at the start of the survey was assessed visually and given a qualitative value from none ( $0-5 \%$ cover), some ( $5-$ $95 \%)$, or full $(95-100 \%)$. We used historical 24-hour precipitation data from the most proximal National Oceanic and Atmospheric Administration (NOAA) weather station (https://www.weather.gov/rlx/climatemaps) to record whether or not precipitation had occurred in the area within 24 hours of the site visit.

\section{Imidacloprid Exposure}

Soil sampling. - In spring 2020, soil was collected in each plot and sent to the U.S. Geological Survey (USGS) Neonicotinoid Laboratory in Sacramento, California. Soil cores were collected by removing leaf litter from the soil surface and inserting a $2.54 \mathrm{~cm}$ diameter soil core probe. Sixteen soil samples were systematically collected in each plot, with each point occurring $3.5 \mathrm{~m}$ from the subplot center outward toward each subplot corner. The 16 cores were homogenized into one soil sample per plot.

Soil imidacloprid extraction and quantification. - In the USGS lab, ca. five grams of freeze-dried, homogenized soil was extracted per sample and mixed with carbon (500 mg) and magnesium sulfate $\left(900 \mathrm{mg}\right.$ ). Samples were then spiked with a surrogate (imidacloprid- $\mathrm{d}_{4}$; Cambridge Isotope, Andover, MA) and extracted using acetonitrile (ACN) solvent (1500 psi; $\left.100{ }^{\circ} \mathrm{C}\right)$. Nitrogen gas was then used to reduce the extracts. The final extract was centrifuged to 
remove unwanted particulates, then evaporated to $0.2 \mathrm{~mL}$ and stored in a freezer at $-20^{\circ} \mathrm{C}$ until analysis.

Samples were analyzed using liquid chromatography tandem mass spectrometry (LCMS/MS). Compound flow rate was $0.6 \mathrm{~mL}$ per minute set at $30^{\circ} \mathrm{C}$. Mobile phases were ACN (A) and water with five millimolar $(\mathrm{mM})(\mathrm{B})$. The gradient of the column was $2 \%: 98 \%(\mathrm{~A}: \mathrm{B})$ from 0 to 2 minutes; increased to $50 \%: 50 \%$ (A:B) for 2 to 4 minutes and held for 3 minutes; 7 to 7.5 minute decrease back to $2 \%: 98 \%(\mathrm{~A}: \mathrm{B})$ and held for 4.5 minutes for a total processing time of 12 minutes. Detection level for this method was $0.2 \mathrm{ng} / \mathrm{g}$, with surrogate recovery used to assess performance of the analysis. A more detailed and technical description of the LC-MS/MS analysis can be found in Hladik and Calhoun (2012).

Ant sampling for imidacloprid bioaccumulation. - An exploratory analysis was conducted to examine if imidacloprid could be detected in ants captured in hemlock forests treated with imidacloprid. To ensure we had sufficient ant biomass for chemical analyses, we grouped the 18 samples from treated plots consisting of all ants captured in each of three sampling replicates by general geographic area for a total of 5 samples. The groups were Fern Creek and Fern Buttress treatment sites ( $n=5$ plots), GARI sites ( $n=6$ plots), Poll's Branch sites ( $n=2$ plots), Burnwood and Bridge Buttress sites ( $n=3$ plots), and Kaymoor sites ( $n=2$ plots). Samples were sent overnight to the USGS Neonicotinoid Laboratory in Sacramento, California. Each sample was ground to a fine powder and analyzed individually by liquid chromatography tandem mass spectrometry (LC-MS/MS) for the presence of imidacloprid and common imidacloprid metabolites. 


\section{Statistical Analyses}

We used linear regression models with a model selection approach (Akaike Information Criterion corrected for small sample size [AICc ]) to investigate whether imidacloprid influenced relative abundance and diversity of ants. Due to small sample sizes of the other species captured, the relative abundance analysis was restricted to the dominant ant species (Aphaenogaster picea), which accounted for $97.5 \%$ of total ant captures. To account for uneven sampling effort, our response variable for relative abundance was captures-per-unit effort (CPUE), which was calculated by dividing the total number of A. picea captures per plot by the number of individual subplot samples taken from the plot over the three survey replications. For ant diversity, our response variable was Simpson's diversity index score (range $=0-1$; Magurran 2004). We computed diversity index scores for each plot using total captures across the three surveys. For the 12 samples with missing data, we estimated counts as the mean number of captures per species from the remaining samples in that subplot, which is equivalent to CPUE.

We used a three-stage model selection approach to select the most informative environmental and imidacloprid predictors for A. picea CPUE and ant species diversity. In all stages, we used $\triangle \mathrm{AIC} c$ to determine the strength of model support and considered $\triangle \mathrm{AIC} c$ scores $<2$ to have strong support, and scores $<7$ to have some support (Burnham et al. 2011). In the first stage, we ranked singular environmental predictors for A. picea CPUE and ant species diversity. In the second stage, we incorporated additive and interaction terms in the model selection for the two most supported environmental predictors. In the final stage, we used the most parsimonious environmental predictor model as the null model to assess imidacloprid effects.

Our candidate environmental predictors used in the relative abundance and diversity analyses included soil $\mathrm{pH}$ (converted to $\mathrm{H}^{+}$), soil moisture (\% volumetric water content [VWC]), 
soil depth (duff depth and litter depth combined), canopy cover (\%), and total tree DBH (trees $\geq$ $12.7 \mathrm{~cm}$ ) in the plot. Candidate imidacloprid predictors included treatment (a categorical variable representing whether the site was located in a treated or non-treated area), treated tree DBH (i.e., total DBH of treated trees $>12.7 \mathrm{~cm} \mathrm{DBH}$ in the plot), and years since treatment (YST; i.e., mean number of years since trees in the plot were treated). We standardized all continuous variables to facilitate model convergence.

We conducted two focal analyses for relative abundance and one for species diversity. The first analysis included all control and treatment plots to determine if treatment presence and treated tree DBH influenced A. picea CPUE and ant species diversity score. The second analysis (CPUE-only) was restricted to treatment plots to test the imidacloprid predictor YST. We accounted for the potential influence of treatment intensity by including candidate models with additive and interaction terms between YST and treated tree DBH. We excluded species diversity from this analysis because only 4 of the 18 treatment plots had species diversity scores $>0$. For all focal analyses, we ranked individual imidacloprid predictors using AIC $c$. For the supported models, the direction (negative or positive), magnitude (slope), and strength of the effect (85\% confidence interval [CI]; Arnold 2010) was assessed for imidacloprid variables. We conducted all analyses using program $\mathrm{R}$ (version 3.6.3). We ranked models using AICcmodavg (version 2.1-1; Mazerolle 2019). The package vegan (version 2.5-7) was used to create species diversity indices.

\section{RESULTS}

We captured a total of 5 species and 17,626 ants, with 10,324 ants captured in control plots and 7,302 in treatment plots (Table 3-1). Mean CPUE in control and treatment plots was 46.68 (range 
$=5.50-101.67)$ and 33.65 (range $=8.50-62.75)$, respectively (Table 3-1). Mean Simpson's diversity index score in control plots was 0.05 (range $=0.00-0.52$ ) and in treatment plots was 0.01 (range $=0.00-0.21)$. Imidacloprid was detected in the soil at 11 of the 18 treatment plots (Table 3-2). At those 11 plots, the mean imidacloprid concentration was $28.36 \pm 63.24 \mathrm{ng} / \mathrm{g}$ (Table 3-2). Imidacloprid olefin and imidacloprid urea was detected in one and two plots, respectively. Both plots with imidacloprid olefin and imidacloprid urea also had detectable imidacloprid concentrations. Imidacloprid was not detected at any control plots (Table 3-2). Two treatment plots did not contain any treated trees within the plot boundary but had treated trees just outside the sample plot boundary. Mean surrogate recovery scores for the soil imidacloprid concentration analysis was $46 \%$ (range $=29-72 \%$; Table 3-2). Due to generally low surrogate recovery rates, we did not use soil concentration as an environmental predictor in analyses.

\section{Relative Abundance}

For the control and treatment plots analysis, the intercept-only model was the most parsimonious environmental model for $A$. picea $\mathrm{CPUE}(\triangle \mathrm{AIC} c=0.00$; Table 3-3). The most parsimonious imidacloprid model included treated tree $\mathrm{DBH}(\triangle \mathrm{AIC} c=0.00)$, followed by treatment presence $(\triangle \mathrm{AIC} c=2.46)$ and the null model $(\triangle \mathrm{AIC} c=3.31 ;$ Table $3-3)$. The treated tree $\mathrm{DBH}$ model estimated that $A$. picea CPUE was negatively correlated with total treated tree $\mathrm{DBH}$, and the coefficient CI did not overlap 0 (Table 3-4; Figure 3-2). The treatment presence model estimated that treatment presence had a strong negative relationship with A. picea CPUE, and the coefficient CI did not overlap 0 (Table 3-4; Figure 3-3).

For the treatment plots-only analysis, the intercept-only model was the most parsimonious environmental model for $A$. picea $\operatorname{CPUE}(\triangle \mathrm{AIC} c=0.00$; Table 3-5). The intercept- 
only model also received the highest support in the focal analysis, but all three imidacloprid models had some support $(\triangle \mathrm{AIC}=2.99-6.91$; Table 3-5). The estimated effect of YST on $A$. picea CPUE was strongly dependent on how the effect of treated tree $\mathrm{DBH}$ was incorporated in the model. When treated tree DBH was not included as a predictor, CPUE decreased slightly with YST (Figure 3-4a), with the coefficient CI overlapping 0 (Table 3-4). When treated tree DBH was included as an additive term, CPUE increased slightly with YST and decreased with treated tree DBH (Figure 3-4b). The coefficient CI overlapped 0 for YST, but did not overlap 0 for treated tree DBH (Table 3-4). When treated tree DBH was included as an interaction term, CPUE dramatically increased and decreased with YST when treated tree DBH was small and large, respectively (Figure 3-4c), but the coefficient CI for the interaction term overlapped 0 (Table 3-4). The individual graphs in Figure 3-4c represent the range of total treated tree DBH sizes found in the treated plots. The mean total treated tree $\mathrm{DBH}$ in the plots was $186 \mathrm{~cm}$, and the $94 \mathrm{~cm}$ and $256 \mathrm{~cm}$ graphs represent the mean +/- 1 standard deviation.

\section{Species Diversity}

The intercept-only model was the most parsimonious environmental model for estimating ant diversity in control and treatment plots $(\triangle \mathrm{AIC} c=0.00$; Table 3-6). The intercept-only model also received the highest support in the focal analysis, but the treatment presence and treated tree DBH models also received strong support $(\triangle \mathrm{AIC} c=0.62$ and 1.59 , respectively; Table 3-6). The treatment presence model estimated that ant diversity was negatively associated with treatment presence, but the coefficient CI overlapped 0 (Table 3-6). The treated tree DBH model estimated a weak negative relationship between ant diversity and treated tree $\mathrm{DBH}$, but the coefficient CI overlapped 0 (Table 3-6). 


\section{Imidacloprid Bioaccumulation}

One ant sample had detectable levels of imidacloprid. The sample included 1,950 ants collected from Bridge Buttress, Burnwood 1, and Burnwood 2 with an imidacloprid concentration of 28.1 ng/g (dry weight; surrogate recovery $=111.9 \%$ ). Two imidacloprid metabolites (imidacloprid urea and imidacloprid olefin) were not detected in the ant sample. All ants in the sample were $A$. picea. The other 4 sample groups had no detectable levels of imidacloprid, imidacloprid urea, or imidacloprid olefin.

\section{DISCUSSION}

To our knowledge, this is the first field study examining the effects of imidacloprid treatments on ant populations in eastern hemlock forests. In support of our hypotheses, we found that relative abundance of ants was negatively associated with imidacloprid treatments. We also found that ant communities in eastern hemlock forests in NERI and GARI were dominated by one species, A. picea. Abundance of A. picea was negatively impacted by imidacloprid and rebounded faster over time in plots with a lower total treated tree DBH. While we found some evidence that ant diversity was negatively impacted by imidacloprid treatments, the effect was relatively weak. We hypothesize that the other ant species populations could benefit from a reduction in A. picea due to competitive release, potentially offsetting direct impacts of imidacloprid to individuals.

Our finding that imidacloprid negatively impacted relative ant abundance is consistent with results in other systems. For example, Peck (2009) found that over a five-year span, ant captures in soil cores taken from turfgrass treated with imidacloprid were reduced by $70 \%$ compared to untreated turfgrass. Sánchez-Bayo et al. (2007) found lower densities of ant 
populations near imidacloprid treated eggplant crops compared to controls. Penn (2016) found significant impacts to ant evenness and diversity in a soybean crop treated with imidacloprid, while ant species richness was not affected. They also found that the response to treatment varied greatly among species, with half of the species increasing in abundance and the other half decreasing.

Sublethal effect studies indicate there are several pathways in which ant populations could be affected by imidacloprid treatments. Several studies documented an imidaclopridinduced decrease in grooming behavior in leaf-cutting ants (Myrmicinae) that led to increased rates of lethal fungal infections (Santos et al. 2007, Galvanho et al. 2013, Silva and Samuels 2013). Thiel and Kohler (2016) found that ants (Lasius niger and L. flavus) exposed to sublethal concentration amounts of imidacloprid significantly decreased foraging behavior and observed poor foraging success in exposed worker ants. They also observed a significant increase in interspecific aggressive behavior, which led to higher rates of mortality. Wang et al. (2015a) found reduced brood-tending behavior, an increase in time for larval emergence, and no pupae or worker ants (Solenopsis invicta) produced at varying sublethal concentrations of imidacloprid.

Uptake and bioaccumulation of imidacloprid is well documented in insects (e.g., Nauen and Elbert 1997, Nauen et al. 2001, Suchail et al. 2004, Zaworra et al. 2019, Crayton et al. 2020, Huang et al. 2021), but to our knowledge this is the first study that has investigated ants. Even though only one sample had detectable levels of imidacloprid, this finding presents evidence that it is possible for ants to uptake imidacloprid years after treatment has been applied in the area. For example, the ant sample that was positive for imidacloprid was from a combined sample that included ants captured at Bridge Buttress and Burnwood plots, which had not been treated since 2015. Many of the plots included in the other 4 samples that did not have ants with detectable 
levels of imidacloprid were treated 3 years prior to sample collection, indicating that site factors influence imidacloprid persistence. The pathway in which ants are uptaking imidacloprid is currently unknown. It could be attributed to ingesting plant or insect material that is contaminated with imidacloprid, or direct contact with imidacloprid in the soil (Peijnenburg et al. 2012). Rabitsch (1997) examined the internal tissue concentrations of bioaccumulated heavy metals in three Formicidae species. They found diet to be the largest contributor of heavy metal concentrations, with the midgut, Malpighian tubules, and hindgut being the three most affected body parts. Dietary components for species in the genus Aphaenogaster include other small invertebrates, seeds, and plant material (Holldobler and Wilson 1990, Fisher and Cover 2007), all of which could introduce imidacloprid into their digestive tracts. In our study system, imidacloprid has also been detected in aquatic invertebrates (Crayton et al. 2020), stream salamanders (Crayton et al. 2020), eastern red-backed salamanders (Plethodon cinereus; Chapter 2), and a ground beetle species (Carabus goryi; Burke 2021). The extent to which imidacloprid biomagnifies throughout food webs is unknown, but there is some evidence of imidacloprid biomagnification in agroecosystems (Taylor et al. 2015). Ants with imidacloprid bioaccumulation provide a possible route of dietary exposure for a multitude of forest-dwelling taxa that consume ants, including amphibians, reptiles, birds, other arthropods, and mammals (reviewed in Bequaert 1922).

Decreased prey availability from HWA imidacloprid treatments is of concern for woodland salamanders. We found that abundance of one major dietary component, ants, was negatively impacted by imidacloprid. A concurrent study in our study system found that abundance of collembolans, another major dietary component (Burton 1976, Maglia 1996), was negatively impacted by imidacloprid (Burke 2021). Thus, reduced prey availability could be an 
explanatory factor for our finding in Chapter 2 that salamanders in high treatment intensity areas had reduced body condition. Thus, we recommend that forest managers be cognizant of the size and spacing of trees being treated within treatment zones to reduce local application intensity. We suggest following the optimized treatment dosage outlined in Benton at al. (2016), which recommends using a maximum of 362 Coretect $^{\circledR}$ tablets or 181 ounces of water soluble packets per acre. Where possible, we also recommend spacing the treatments out over a wider area within the treatment acre, so as not to apply the bulk of the treatment allowance in a small area.

\section{Literature Cited}

Adamchuk, V. I., M. T. Morgan, and D. R. Ess. 1999. An automated sampling system for measuring soil $\mathrm{pH}$. Transactions of the ASAE 42:885-891.

Andersen, A. N. 1997. Using ants as bioindicators: Multiscale issues in ant community ecology. Ecology and Society 1:1-17.

Arnold, T. W. 2010. Uninformative parameters and model selection using Akaike's information criterion. Journal of Wildlife Management 74:1175-1178.

Barbieri, R. F., P. J. Lester, A. S. Miller, and K. G. Ryan. 2013. A neurotoxic pesticide changes the outcome of aggressive interactions between native and invasive ants. Proceedings of the Royal Society 280.

Beattie, A. J., and D. C. Culver. 1983. The nest chemistry of two seed-dispersing ant species. Oecologia 56:99-103.

Bequaert, J. 1922. The predaceous enemies of ants. Pages 271-331 in. Bulletin of the American Museum of Natural History. Volume 45. New York, New York, USA.

Bolton, B. 1994. Identification guide to the ant genera of the world. Harvard University Press. Cambridge, Massachusetts, USA.

Burton, T. M. 1976. An analysis of the feeding ecology of the salamanders (Amphibia, Urodela) of the Hubbard Brook Experimental Forest, New Hampshire. Journal of Herpetology 10:187-204.

Burnham, K. P., D. R. Anderson, and K. P. Huyvaert. 2011. AIC model selection and multimodel inference in behavioral ecology: some background, observations, and comparisons. Behavioral Ecology and Sociobiology 65:23-35.

Brown, D. J., D. B. Preston, E. Ozel, and M. R. J. Forstner. 2013. Wildfire impacts on red imported fire ant captures around forest ponds in the Lost Pines ecoregion of Texas. Journal of Fish and Wildlife Management 4:129-133.

Cerdà, A., and M. F. Jurgensen. 2008. The influence of ants on soil and water losses from an orange orchard in eastern Spain. Journal of Applied Entomology 132:306-314.

Cowles, R. S., C. S.-J. Cheah, and M. E. Montgomery. 2005. Comparing systemic imidacloprid application methods for controlling hemlock woolly adelgid. Pages 169-172 in.

Proceedings, 16th U.S. Department of Agriculture interagency research forum on gypsy moth and other invasive species. USDA Forest Service, Hamden, Connecticut. 
Cowles, R. S., M. E. Montgomery, and C. S.-J. Cheah. 2006. Activity and residues of imidacloprid applied to soil and tree trunks to control hemlock woolly adelgid (Hemiptera: Adelgidae) in forests. Journal of Economic Entomology 99:1258-1267.

Crayton, S. M. 2019. Stream salamander and benthic macroinvertebrate community responses to imidacloprid exposure. Thesis, West Virginia University, Morgantown, West Virginia, USA.

Crayton, S. M., P. B. Wood, D. J. Brown, A. R. Millikin, T. J. Mcmanus, T. J. Simpson, K. Ku, and Y. Park. 2020. Bioaccumulation of the pesticide imidacloprid in stream organisms and sublethal effects on salamanders. Global Ecology and Conservation 24:e01292. Elsevier

Del Toro, I., R. R. Ribbons, and A. M. Ellison. 2015. Ant-mediated ecosystem functions on a warmer planet: Effects on soil movement, decomposition and nutrient cycling. Journal of Animal Ecology 84:1233-1241.

Del Toro, I., R. R. Ribbons, and S. L. Pelini. 2012. The little things that run the world revisited: a review of ant-mediated ecosystem services and disservices (Hymenoptera: Formicidae). Myrmecological News 17:133-146.

Dilling, C., P. Lambdin, J. Grant, and R. Rhea. 2009. Community response of insects associated with eastern hemlock to imidacloprid and horticultural oil treatments. Environmental Entomology 38:53-66.

Ellison, A. M., J. Chen, D. Díaz, C. Kammerer-burnham, and M. Lau. 2005. Changes in ant community structure and composition associated with hemlock decline in New England. Pages 280-289 in. Proceedings of Third Symposium on Hemlock Woolly Adelgid. USDA Forest Service, Forest Health Technology Enterprise Team, Morgantown, West Virginia.

Ellison, A. M. 2014. Experiments are revealing a foundation species: A case study of eastern hemlock (Tsuga canadensis). Advances in Ecology 2014:1-11.

Fisher, B. L., and S. P. Cover. 2007. Ants of North America: a guide to the genera. First Edit. University of California Press.

Folgarait, P. J. 1998. Ant biodiversity and its relationship to ecosystem functioning: a review. Biodiversity and Conservation 7:1221-1244.

Frouz, J., and V. Jilková. 2008. The effect of ants on soil properties and processes (Hymenoptera: Formicidae ). Myrmecological News 11:191-199.

Frouz, J., M. Rybníček, P. Cudlín, and E. Chmelíková. 2008. Influence of the wood ant, Formica polyctena, on soil nutrient and the spruce tree growth. Journal of Applied Entomology 132:281-284.

Galvanho, J. P., M. P. Carrera, D. D. O. Moreira, M. Erthal, C. P. Silva, and R. I. Samuels. 2013. Imidacloprid inhibits behavioral defences of the leaf-cutting ant Acromyrmex subterraneus subterraneus (Hymenoptera: Formicidae). Journal of Insect Behavior 26:1-13.

Green, W. P., D. E. Pettry, and R. E. Switzer. 1999. Structure and hydrology of mounds of the imported fire ants in the southeastern United States. Geoderma 93:1-17.

Gouger, R. J. 1971. Control of Adelges tsugae on hemlock in Pennsylvania. Scientific Tree Topics 3:1-9.

Hakeem, A. 2008. Non-target effect of imidacloprid on the predatory arthropod guild on eastern hemlock, Tsuga canadensis (L.) Carriere, in the southern Appalachians. Thesis. University of Tennessee, Knoxville, Tennessee, USA.

Havill, N. P., L. C. Vieira, and S. M. Salom. 2014. Biology and control of hemlock woolly adelgid. USDA Forest Service. Forest Health Technology Enterprise Team. 
Hladik, M., and D. Calhoun. 2012. Analysis of the herbicide Diuron, three Diuron degradates, and six neonicotinoid insecticides in water-Method details and application to two Georgia streams. U.S. Geological Survey Scientific Investigations Report 5206:1-10.

Holec, M., and J. Frouz. 2006. The effect of two ant species Lasius niger and Lasius flavus on soil properties in two contrasting habitats. European Journal of Soil Biology 42:213-217.

Hölldobler, B., and E. O. Wilson. 1990. The Ants. Belknap Press, Cambridge, Massachusetts.

Huang, H. T., and P. Yang. 1987. A tropical ant is used to control insect pests in southern China. BioScience 37:665-671.

Huang, A., N. W. van den Brink, L. Buijse, I. Roessink, and P. J. van den Brink. 2021. The toxicity and toxicokinetics of imidacloprid and a bioactive metabolite to two aquatic arthropod species. Aquatic Toxicology 235:105837.

Ivanov, K., O. M. Lockhart, J. Keiper, and B. M. Walton. 2011. Status of the exotic ant Nylanderia flavipes (Hymenoptera: Formicidae) in northeastern Ohio. Biological Invasions 13:1945-1950.

Jeschke, P., and R. Nauen. 2008. Neonicotinoids - from zero to hero in insecticide chemistry. Pest Management Science 63:1084-1098.

Kendrick, J. A., R. R. Ribbons, A. T. Classen, and A. M. Ellison. 2015. Changes in canopy structure and ant assemblages affect soil ecosystem variables as a foundation species declines. Ecosphere 6:77.

Kilpeläinen, J., L. Finér, P. Niemelä, T. Domisch, S. Neuvonen, M. Ohashi, A. C. Risch, and L. Sundström. 2007. Carbon, nitrogen and phosphorus dynamics of ant mounds (Formica rufa group) in managed boreal forests of different successional stages. Applied Soil Ecology 36:156-163.

King, T. J. 1977. The plant ecology of ant-hills in calcareous grasslands: I. patterns of species in relation to ant-hills in southern England. The Journal of Ecology 65:235.

Kreutzweiser, D. P., D. G. Thompson, and T. A. Scarr. 2009. Imidacloprid in leaves from systemically treated trees may inhibit litter breakdown by non-target invertebrates. Ecotoxicology and Environmental Safety 72:1053-1057.

Lockaby, B. G., and J. Adams. 1985. Pedoturbation of a forest soil by fire ants. Soil Science Society of America Journal 49:220-223.

Maglia, A. M. 1996. Ontogeny and feeding ecology of the red-backed salamander, Plethodon cinereus. Copeia 1996:576-586.

Magurran, A. E. 2004. Measuring biological diversity. Blackwell Publishing, Malden, Massachusetts, USA.

Mazerolle, M. 2019. Package "AICcmodavg". Model selection and multimodel inference based on (Q)AIC(c). Available from https://web.archive.org/web/20190710031635/https://cran.rproject.org/web/packages/AICcmodavg/AICcmodavg.pdf.

McClure, M. S. 1991. Density-dependent feedback and population cycles in Adelges tsugae (Homoptera: Adelgidae) on Tsuga canadensis. Environmental Entomology 20:258-264.

McClure, M. S., S. M. Salom, and K. S. Shields. 1996. Hemlock woolly adelgid. Volume 96. USDA Forest Service, Forest Health Technology Enterprise Team, Morgantown, WV.

Mody, K., and K. E. Linsenmair. 2004. Plant-attracted ants affect arthropod community structure but not necessarily herbivory. Ecological Entomology 29:217-225.

National Oceanic and Atmospheric Administration. 2016. Summary of Monthly Normals. <http://www.ncdc.noaa.gov/cdo-web/datatools/normals>. Accessed 17 Aug 2020. 
National Park Service. 2016. Foundation Document: New River Gorge National River. National Park Service, Glen Jean, West Virginia, USA.

Nauen, R., U. Ebbinghaus-Kintscher, and R. Schmuck. 2001. Toxicity and nicotinic acetylcholine receptor interaction of imidacloprid and its metabolites in Apis mellifera (Hymenoptera: Apidae). Pest Management Science 57:577-586.

Nauen, R., and A. Elbert. 1997. Apparent tolerance of a field-collected strain of Myzus nicotianae to imidacloprid due to strong antifeeding responses. Pesticide Science 49:252258.

Nkem, J. N., L. A. Lobry De Bruyn, C. D. Grant, and N. R. Hulugalle. 2000. The impact of ant bioturbation and foraging activities on surrounding soil properties. Pedobiologia 44:609621.

Orwig, D. A., A. A. B. Plotkin, E. A. Davidson, H. Lux, K. E. Savage, and A. M. Ellison. 2013. Foundation species loss affects vegetation structure more than ecosystem function in a northeastern USA forest. PeerJ 1:1-29.

Orwig, D. A., R. C. Cobb, A. W. D. Amato, M. L. Kizlinski, and D. R. Foster. 2008. Multi-year ecosystem response to hemlock woolly adelgid infestation in southern New England forests. Canadian Journal of Forest Research 38:834-843.

Paluh, D. J., C. Eddy, K. Ivanov, C.-A. M. Hickerson, and C. D. Anthony. 2015. Selective foraging on ants by a terrestrial polymorphic salamander. The American Midland Naturalist 174:265-277.

Pauley, T. K. 1978. Food types and distribution as a plethodon habitat partitioning factor. Bulletin of the Maryland Herpetological Society 14:79-82.

Peck, D. C. 2009. Long-term effects of imidacloprid on the abundance of surface- and soil-active nontarget fauna in turf. Agricultural and Forest Entomology 11:405-419.

Peijnenburg, W., E. Capri, C. Kula, M. Liess, R. Luttik, M. Montforts, P. Sousa, K. Nienstedt, J. Rombke, J. P. Sousa, and J. Jensen. 2012. Evaluation of exposure metrics for effect assessment of soil invertebrates. Critical Reviews in Environmental Science and Technology 42:1862-1893.

Penn, H. J. 2016. Effects of landscape, intraguild interactions, and a neonicotinoid on natural enemy and pest interactions in soybeans. Dissertation. University of Kentucky. Lexington, Kentucky, USA.

Petal, J. 1991. The role of ants in nutrient cycling in forest ecosystems. Pages 167-170 in. First European Congress of Social Insects. Leuven University Press, Leuven, Belgium.

Porter, S. D., and W. R. Tschinkel. 1987. Foraging in Solenopsis invicta (Hymenoptera: Formicidae): Effects of weather and season. Environmental Entomology 16:802-808.

Rabitsch, W. B. 1997. Tissue-specific accumulation patterns of $\mathrm{Pb}, \mathrm{Cd}, \mathrm{Cu}, \mathrm{Zn}, \mathrm{Fe}$, and $\mathrm{Mn}$ in workers of three ant species (Formicidae, Hymenoptera) from a metal-polluted site. Archives of Environmental Contamination and Toxicology 32:172-177.

Reynolds, W. N. 2008. Imidacloprid insecticide treatments for hemlock woolly adelgid, Adelges tsugae Annand (Hemiptera:Adelgidae), affect a non-target soil arthropod community surrounding eastern hemlock, Tsuga canadensis (L.) Carriere. Thesis. University of Tennessee, Knoxville, USA.

Rust, A., K. Michael, A. Donald, H. John, and J. H. Klotz. 2004. Delayed toxicity as a critical factor in the efficacy of aqueous baits for controlling argentine ants (Hymenoptera: Formicidae). Journal of Economic Entomology 97:1017-1024. 
Sackett, T. E., S. Record, S. Bewick, B. Baiser, N. J. Sanders, and A. M. Ellison. 2011. Response of macroarthropod assemblages to the loss of hemlock (Tsuga canadensis), a foundation species. Ecosphere 2:1-16.

Sánchez-Bayo, F., H. Yamashita, R. Osaka, M. Yoneda, and K. Goka. 2007. Ecological effects of imidacloprid on arthropod communities in and around a vegetable crop. Journal of Environmental Science and Health - Part B Pesticides, Food Contaminants, and Agricultural Wastes 42:279-286.

Sanchez-Bayo, F., H. A. Tennekes, and K. Goka. 2013. Impact of systemic insecticides on organisms and ecosystems. Pages 365-414 in Insecticides - Development of Safer and More Effective Technologies.

Santos, A. V., B. L. de Oliveira, and R. I. Samuels. 2007. Selection of entomopathogenic fungi for use in combination with sub-lethal doses of imidacloprid: Perspectives for the control of the leaf-cutting ant Atta sexdens rubropilosa Forel (Hymenoptera: Formicidae). Mycopathologia 163:233-240.

Sappington, J. D. 2018. Imidacloprid alters ant sociobehavioral traits at environmentally relevant concentrations. Ecotoxicology 27:1179-1187.

Scharenbroch, B., and J. Bockheim. 2007. Impacts of forest gaps on soil properties and processes in old growth northern hardwood-hemlock forests. Plant and Soil 297:219-233.

Silcox, C. A. 2002. Using imidacloprid to control hemlock woolly adelgid. Pages 280-287 in. Proceedings in hemlock woolly adelgid in the eastern United States. NJ Agricultural Experiment Station, New Brunswick, New Jersey.

Silva, C. P., and R. I. Samuels. 2013. Imidacloprid inhibits behavioral defences of the leafcutting ant Acromyrmex subterraneus subterraneus (Hymenoptera: Formicidae). Journal of Insect Behavior 26:1-13.

Spectrum Technologies. 2008. FieldScout TDR100 Soil Moisture Meter User's Manual. Spectrum Technologies, INC., Plainfield, Illinois, USA.

Stadler, B., A. Schramm, and K. Kalbitz. 2006. Ant-mediated effects on spruce litter decomposition, solution chemistry, and microbial activity. Soil Biology and Biochemistry 38:561-572.

Suchail, S., G. De Sousa, R. Rahmani, and L. P. Belzunces. 2004. In vivo distribution and metabolisation of 14C-imidacloprid in different compartments of Apis mellifera L. Pest Management Science 60:1056-1062.

Tattar, T. A., J. A. Dotson, and M. S. Ruizzo. 1998. Translocation of imidacloprid in three tree species. Journal of Arboriculture 24:54-56.

Taylor, S. V, H. J. Burrack, R. M. Roe, and J. S. Bacheler. 2015. Systemic imidacloprid affects intraguild parasitoids differently. PLoS ONE 1-13.

Thiel, S., and H.-R. Köhler. 2016. A sublethal imidacloprid concentration alters foraging and competition behaviour of ants. Ecotoxicology 25:814-823.

Tiede, Y., J. Schlautmann, D. A. Donoso, C. I. B. Wallis, J. Bendix, R. Brandl, and N. Farwig. 2017. Ants as indicators of environmental change and ecosystem processes. Ecological Indicators 83:527-537.

Underwood, E. C., and B. L. Fisher. 2006. The role of ants in conservation monitoring: If, when, and how. Biological Conservation 132:166-182.

Vanderhorst, J., J. Jeuck, and S. Gawler. 2007. Vegetation classification and mapping of New River Gorge National River, West Virginia. US Department of the Interior, National Park Service. Northeast Region, Philadelphia, Pennsylvania. 
Vanderhorst, J. P., B. P. Streets, Z. Arcaro, and S. C. Gawler. 2010. Vegetation classification and mapping of Gauley River National Recreation Area, West Virginia. US Department of the Interior, National Park Service. Northeast Region, Philadelphia, Pennsylvania.

Wagner, D., J. B. Jones, and D. M. Gordon. 2004. Development of harvester ant colonies alters soil chemistry. Soil Biology and Biochemistry 36:797-804.

Wang, L., L. Zeng, and J. Chen. 2015a. Impact of imidacloprid on new queens of imported fire ants, Solenopsis invicta (Hymenoptera: Formicidae). Scientific Reports 5:1-8. Nature Publishing Group.

Wang, L., L. Zeng, and J. Chen. 2015b. Sublethal effect of imidacloprid on Solenopsis invicta (Hymenoptera: Formicidae) feeding, digging, and foraging behavior. Environmental Entomology 44:1544-1552.

Wardle, D. A., F. Hyodo, R. D. Bardgett, G. W. Yeates, and M.-C. Nilsson. 2011. Long-term aboveground and belowground consequences of red wood ant exclusion in boreal forest. Ecology 92:645-656.

Warren, R. J., and M. A. Bradford. 2012. Ant colonization and coarse woody debris decomposition in temperate forests. Insectes Sociaux 59:215-221.

Young, R. F., K. S. Shields, and G. P. Berlyn. 1995. Hemlock woolly adelgid (Homoptera: Adelgidae): Stylet bundle insertion and feeding sites. Annals of the Entomological Society of America 88:827-835.

Zaworra, M., H. Koehler, J. Schneider, A. Lagojda, and R. Nauen. 2019. Pharmacokinetics of three neonicotinoid insecticides upon contact exposure in the western honey bee, Apis mellifera. Chemical Research in Toxicology 32:35-37. 
Table 3-1. Total ant captures by species, captures-per-unit-effort (CPUE), and Simpson's diversity index for control and treatment plots located in treated or untreated eastern hemlock (Tsuga canadensis) forests in Gauley River National Recreation Area and New River Gorge National Park and Preserve, West Virginia, USA. Site codes that end in " $T$ " indicate treatment plots, while codes ending in "C" indicate control plots. To account for uneven sampling effort, we calculated CPUE by dividing the total number of Aphaenogaster picea captures by the total number of subplot samples per plot.

\begin{tabular}{|c|c|c|c|c|c|c|c|}
\hline $\begin{array}{l}\text { Site } \\
\text { Code }\end{array}$ & $\begin{array}{c}\text { Aphaenogaster } \\
\text { picea }\end{array}$ & $\begin{array}{c}\text { Aphaenogaster } \\
\text { tennesseensis }\end{array}$ & $\begin{array}{c}\text { Camponotus } \\
\text { pennsylvanicus }\end{array}$ & $\begin{array}{c}\text { Lasius } \\
\text { aphidicola }\end{array}$ & $\begin{array}{l}\text { Myrmica } \\
\text { latifrons }\end{array}$ & CPUE & $\begin{array}{c}\text { Simpson's } \\
\text { Diversity } \\
\text { Index }\end{array}$ \\
\hline BBC & 1220 & 0 & 0 & 0 & 0 & 101.67 & 0.00 \\
\hline BBT & 753 & 0 & 0 & 0 & 0 & 62.75 & 0.00 \\
\hline BW1C & 826 & 0 & 0 & 0 & 0 & 68.83 & 0.00 \\
\hline BW1T & 719 & 0 & 0 & 0 & 0 & 59.09 & 0.00 \\
\hline BW2C & 716 & 0 & 3 & 0 & 0 & 59.67 & 0.01 \\
\hline BW2T & 478 & 0 & 0 & 0 & 0 & 39.83 & 0.00 \\
\hline CFC & 779 & 0 & 0 & 0 & 37 & 64.92 & 0.09 \\
\hline CFT & 382 & 1 & 0 & 0 & 0 & 31.83 & 0.01 \\
\hline ECC & 168 & 198 & 7 & 0 & 0 & 14.00 & 0.52 \\
\hline ECT & 354 & 0 & 0 & 0 & 0 & 29.50 & 0.00 \\
\hline FBC & 633 & 0 & 0 & 0 & 0 & 61.70 & 0.00 \\
\hline FBT & 627 & 0 & 0 & 0 & 0 & 45.40 & 0.00 \\
\hline FC1C & 396 & 0 & 0 & 0 & 0 & 33.00 & 0.00 \\
\hline FC1T & 102 & 0 & 0 & 0 & 0 & 8.50 & 0.00 \\
\hline $\mathrm{FC} 2 \mathrm{C}$ & 587 & 0 & 9 & 0 & 0 & 48.92 & 0.03 \\
\hline FC2T & 270 & 0 & 0 & 0 & 0 & 22.50 & 0.00 \\
\hline $\mathrm{FC} 4 \mathrm{C}$ & 407 & 35 & 0 & 0 & 0 & 33.92 & 0.15 \\
\hline FC4T & 154 & 0 & 0 & 0 & 0 & 15.20 & 0.00 \\
\hline KM1C & 484 & 0 & 0 & 0 & 0 & 40.33 & 0.00 \\
\hline KM1T & 209 & 0 & 0 & 0 & 0 & 17.42 & 0.00 \\
\hline $\mathrm{KM} 2 \mathrm{C}$ & 239 & 0 & 0 & 0 & 0 & 19.92 & 0.00 \\
\hline KM2T & 302 & 0 & 1 & 0 & 0 & 25.17 & 0.01 \\
\hline NTC & 66 & 0 & 0 & 0 & 0 & 5.50 & 0.00 \\
\hline NTT & 699 & 0 & 0 & 0 & 0 & 58.25 & 0.00 \\
\hline PB1C & 318 & 0 & 0 & 0 & 0 & 26.50 & 0.00 \\
\hline PB1T & 191 & 0 & 0 & 0 & 0 & 15.92 & 0.00 \\
\hline $\mathrm{PB} 2 \mathrm{C}$ & 164 & 0 & 0 & 2 & 0 & 13.67 & 0.02 \\
\hline PB2T & 342 & 0 & 0 & 0 & 0 & 28.50 & 0.00 \\
\hline $\mathrm{RCC}$ & 1044 & 55 & 0 & 0 & 0 & 87.00 & 0.10 \\
\hline $\mathrm{RCT}$ & 478 & 64 & 0 & 0 & 0 & 39.83 & 0.21 \\
\hline SD1C & 684 & 0 & 0 & 0 & 0 & 58.45 & 0.00 \\
\hline SD1T & 370 & 0 & 1 & 0 & 0 & 20.42 & 0.01 \\
\hline $\mathrm{SD} 2 \mathrm{C}$ & 538 & 0 & 5 & 0 & 0 & 44.83 & 0.02 \\
\hline SD2T & 443 & 0 & 0 & 0 & 0 & 55.38 & 0.00 \\
\hline WFC & 690 & 14 & 0 & 0 & 0 & 57.50 & 0.04 \\
\hline WFT & 362 & 0 & 0 & 0 & 0 & 30.17 & 0.00 \\
\hline Total & 17194 & 367 & 26 & 2 & 37 & - & - \\
\hline
\end{tabular}


Table 3-2. Imidacloprid (IMI) and two common imidacloprid metabolite (IMI Olefin, IMI Urea) concentrations in soil samples extracted from eastern hemlock (Tsuga canadensis) forests that were used to investigate the effects of imidacloprid on ant abundance and species diversity in Gauley River National Recreation Area and New River Gorge National Park and Preserve, West Virginia, USA. Dashes represent samples in which no imidacloprid or metabolites were detected. Site codes that end in " $\mathrm{T}$ " indicate treatment plots, while codes ending in " $\mathrm{C}$ " indicate control plots.

\begin{tabular}{|c|c|c|c|c|c|c|c|}
\hline \multirow[b]{2}{*}{ Site Code } & \multicolumn{4}{|c|}{ Concentrations (ng/g dry weight) } & \multirow{2}{*}{$\begin{array}{c}\text { Number of } \\
\text { Treated } \\
\text { Trees }\end{array}$} & \multirow{2}{*}{$\begin{array}{c}\text { Total } \\
\text { Treated } \\
\text { Tree DBH }\end{array}$} & \multirow[b]{2}{*}{$\begin{array}{c}\text { Mean } \\
\text { YST }\end{array}$} \\
\hline & $\begin{array}{c}\text { IMI } \\
\text { Olefin }\end{array}$ & $\begin{array}{c}\text { IMI } \\
\text { Urea }\end{array}$ & IMI & $\begin{array}{c}\text { Surrogate } \\
\text { Recovery (\%) }\end{array}$ & & & \\
\hline $\mathrm{BBC}$ & - & - & - & 47 & & & \\
\hline BBT & - & - & 6.55 & 50 & 5 & 96.0 & 6.40 \\
\hline BW1C & - & - & - & 41 & & & \\
\hline BW1T & - & - & - & 41 & 5 & 149.9 & 7.00 \\
\hline BW2C & - & - & - & 34 & & & \\
\hline BW2T & - & - & - & 39 & 0 & 0.0 & - \\
\hline $\mathrm{CFC}$ & - & - & - & 70 & & & \\
\hline CFT & - & - & 6.48 & 32 & 11 & 243.1 & 3.00 \\
\hline $\mathrm{ECC}$ & - & - & - & 35 & & & \\
\hline ECT & - & - & 20.88 & 45 & 3 & 103.6 & 5.00 \\
\hline FBC & - & - & - & 44 & & & \\
\hline FBT & - & - & - & 72 & 3 & 102.4 & 3.00 \\
\hline $\mathrm{FC} 1 \mathrm{C}$ & - & - & - & 48 & & & \\
\hline $\mathrm{FC} 1 \mathrm{~T}$ & 1.82 & - & 28.52 & 39 & 7 & 247.4 & 7.57 \\
\hline $\mathrm{FC} 2 \mathrm{C}$ & - & - & - & 52 & & & \\
\hline $\mathrm{FC} 2 \mathrm{~T}$ & - & - & 24.58 & 30 & 16 & 586.2 & 8.12 \\
\hline $\mathrm{FC} 4 \mathrm{C}$ & - & - & - & 50 & & & \\
\hline FC4T & - & - & - & 47 & 8 & 319.5 & 8.43 \\
\hline KM1C & - & - & - & 64 & & & \\
\hline KM1T & - & - & 0.87 & 50 & 8 & 256.0 & 7.50 \\
\hline KM2C & - & - & - & 43 & & & \\
\hline KM2T & - & - & - & 51 & 2 & 67.3 & 3.00 \\
\hline NTC & - & - & - & 55 & & & \\
\hline NTT & - & - & - & 53 & 4 & 168.3 & 6.00 \\
\hline PB1C & - & - & - & 35 & & & \\
\hline PB1T & - & - & - & 48 & 4 & 93.8 & 3.00 \\
\hline PB2C & - & - & - & 42 & & & \\
\hline PB2T & 2.63 & 3.98 & 216.53 & 35 & 7 & 186.0 & 3.00 \\
\hline $\mathrm{RCC}$ & - & - & - & 43 & & & \\
\hline RCT & - & - & 2.04 & 40 & 6 & 189.2 & 4.67 \\
\hline SD1C & - & - & - & 29 & & & \\
\hline SD1T & - & - & 4.36 & 41 & 8 & 373.2 & 5.00 \\
\hline SD2C & - & - & - & 34 & & & \\
\hline $\mathrm{SD} 2 \mathrm{~T}$ & - & - & 0.64 & 55 & 0 & 0.0 & - \\
\hline WFC & - & - & - & 61 & & & \\
\hline WFT & - & - & 0.53 & 59 & 7 & 193.0 & 5.00 \\
\hline
\end{tabular}


Table 3-3. Control and treatment plot model selection results for the influence of environmental and imidacloprid variables on Aphaenogaster picea captures-per-unit-effort (CPUE) in eastern hemlock (Tsuga canadensis) forests in Gauley River National Recreation Area and New River Gorge National Park and Preserve, West Virginia, USA. Environmental variables were standardized prior to analyses and included canopy cover (\%; canopy), soil $\mathrm{pH}$ (converted to $\mathrm{H}^{+}$), soil moisture (\% volumetric water content), total tree diameter at breast height (total DBH), and combined duff and litter depth (cm; duff and litter depth). Imidacloprid variables were standardized prior to analyses and included total treated tree diameter at breast height (Tx Tree $\mathrm{DBH}$ ) and treatment presence (a categorical variable representing whether the site was in a treated or non-treated area; Tx Presence). The intercept-only model is represented by ( . ). We ranked each candidate predictor using Akaike's Information Criterion corrected for small sample size $(\triangle \mathrm{AIC} c)$ and included additive $(+)$ and interaction $(\mathrm{x})$ candidate models in the model selection for the two most supported environmental predictors.

\begin{tabular}{|c|c|c|c|c|}
\hline Model & Parameters & $\mathbf{A I C c}$ & $\Delta \mathrm{AICc}$ & $w_{i}$ \\
\hline \multicolumn{5}{|l|}{ Environmental Model Selection } \\
\hline$()$. & 2 & 329.84 & 0.00 & 0.19 \\
\hline Duff and Litter Depth & 3 & 330.05 & 0.21 & 0.17 \\
\hline Total DBH & 3 & 330.50 & 0.65 & 0.14 \\
\hline Soil pH & 3 & 330.57 & 0.73 & 0.13 \\
\hline Total DBH x Duff and Litter Depth & 5 & 330.86 & 1.02 & 0.12 \\
\hline Total DBH + Duff and Litter Depth & 4 & 330.90 & 1.06 & 0.11 \\
\hline Soil Moisture & 3 & 331.89 & 2.05 & 0.07 \\
\hline Canopy & 3 & 332.18 & 2.34 & 0.06 \\
\hline \multicolumn{5}{|l|}{ Imidacloprid Model Results } \\
\hline Tx Tree DBH & 3 & 326.53 & 0.00 & 0.67 \\
\hline Tx Presence & 3 & 328.99 & 2.46 & 0.20 \\
\hline$()$. & 2 & 329.84 & 3.31 & 0.13 \\
\hline
\end{tabular}


Table 3-4. Model coefficient ( $\beta$ ) estimates, standard errors (SE) and 85\% confidence intervals (CI) for supported control and treatment plots and treatment plots-only models in this study investigating potential effects of imidacloprid on Apheanogaster picea captures-per-unit-effort (CPUE) in eastern hemlock (Tsuga canadensis) forests in Gauley River National Recreation Area and New River Gorge National Park and Preserve, West Virginia, USA. Control and treatment plot imidacloprid variables were standardized prior to analyses and included total treated tree diameter at breast height (Tx Tree DBH) and treatment presence (a categorical variable representing whether the site was located in a treated or non-treated area; Tx Presence). Treatment plots-only imidacloprid variables were also standardized prior to analyses and included mean years since treatment (YST), and total treated tree diameter at breast height (Tx Tree DBH). total treated tree DBH and YST were tested together as both an additive (+) and interaction (x) effect. Models included in this table represent imidacloprid variables with Akaike's Information Criterion corrected for small sample size $(\triangle \mathrm{AIC} c)$ scores $<7$.

\begin{tabular}{|c|c|c|c|}
\hline Variables & $\beta$ & SE & $85 \% \mathrm{CI}$ \\
\hline \multicolumn{4}{|c|}{ Control and Treatment Plots } \\
\hline \multicolumn{4}{|c|}{ (. ) + Tx Tree $D B H$} \\
\hline Intercept & 40.17 & 3.52 & $34.98-45.35$ \\
\hline Tx Tree DBH & -8.63 & 3.57 & $-13.89--3.36$ \\
\hline \multicolumn{4}{|l|}{ (. ) + Tx Presence } \\
\hline Intercept & 46.69 & 5.16 & $39.09-54.28$ \\
\hline Tx Presence & -13.04 & 7.29 & $-23.78--2.30$ \\
\hline \multicolumn{4}{|l|}{ Treatment Plots-Only } \\
\hline \multicolumn{4}{|l|}{$()+.Y S T$} \\
\hline Intercept & 31.90 & 4.32 & $25.32-38.49$ \\
\hline YST & -1.21 & 4.46 & $-8.01-5.59$ \\
\hline \multicolumn{4}{|c|}{ (. ) $+Y S T+$ Tx Tree $D B H$} \\
\hline Intercept & 31.90 & 4.03 & $25.74-38.07$ \\
\hline YST & 3.56 & 4.97 & $-4.04-11.16$ \\
\hline Tx Tree DBH & -8.75 & 4.97 & $-16.35--1.15$ \\
\hline \multicolumn{4}{|c|}{ (. ) + YST $x$ Tx Tree DBH } \\
\hline Intercept & 33.69 & 4.81 & $26.29-41.09$ \\
\hline YST & 3.07 & 5.11 & $-4.78-10.93$ \\
\hline Tx Tree DBH & -6.30 & 6.11 & $-15.70-3.10$ \\
\hline YST x Tx Tree DBH & -3.49 & 4.89 & $-11.01-4.03$ \\
\hline
\end{tabular}


Table 3-5. Treatment plots-only model selection results for the influence of environmental and imidacloprid variables on Aphaenogaster picea captures-per-unit-effort (CPUE) in eastern hemlock (Tsuga canadensis) forests in Gauley River National Recreation Area and New River Gorge National Park and Preserve, West Virginia, USA. Environmental variables were standardized prior to analyses and included canopy cover (\%; canopy), soil $\mathrm{pH}$ (converted to $\mathrm{H}^{+}$), soil moisture (\% volumetric water content), total tree diameter at breast height (total DBH), and combined duff and litter depth (cm; duff and litter depth). Imidacloprid variables were standardized prior to analyses and included mean years since treatment (YST) and total treated tree diameter at breast height (Tx Tree $\mathrm{DBH})$. Total treated tree DBH and YST were tested together as both an additive (+) and interaction (x) effect. The intercept-only model is represented by ( . ). We ranked each imidacloprid predictor using Akaike's Information Criterion corrected for small sample size $(\triangle \mathrm{AIC} c)$.

\begin{tabular}{lc|c|c|c}
\hline Model & Parameters & AIC $\boldsymbol{~}$ & $\boldsymbol{\Delta A I C} \boldsymbol{c}$ & $\boldsymbol{w}_{\boldsymbol{i}}$ \\
\hline Environmental Model Selection & & & & \\
$($. $)$ & 2 & 139.48 & 0.00 & 0.24 \\
Canopy & 3 & 139.56 & 0.08 & 0.23 \\
Soil pH & 3 & 139.98 & 0.50 & 0.19 \\
Canopy + Soil pH & 4 & 140.64 & 1.16 & 0.13 \\
Soil Moisture & 3 & 141.80 & 2.32 & 0.08 \\
Duff and Litter Depth & 3 & 142.18 & 2.70 & 0.06 \\
Total DBH & 3 & 142.37 & 2.89 & 0.06 \\
Canopy x Soil pH & 5 & 144.85 & 5.37 & 0.02 \\
& & & & \\
Imidacloprid Model Results & & & & \\
( . ) & 2 & 139.48 & 0.00 & 0.69 \\
YST & 3 & 142.48 & 2.99 & 0.15 \\
YST + Tx Tree DBH & 4 & 142.69 & 3.21 & 0.14 \\
YST x Tx Tree DBH & 5 & 146.39 & 6.91 & 0.02 \\
\hline
\end{tabular}


Table 3-6. Control and treatment plot model selection results, coefficient $(\beta)$ estimates, standard errors (SE) and 85\% confidence intervals (CI) for the influence of environmental and imidacloprid variables on ant species diversity in eastern hemlock (Tsuga canadensis) forests in Gauley River National Recreation Area and New River Gorge National Park and Preserve, West Virginia, USA. The response variable was Simpson's diversity index calculated for each plot. Environmental variables included canopy cover (\%; canopy), soil $\mathrm{pH}$ (converted to $\mathrm{H}^{+}$), soil moisture (\% volumetric water content), total tree diameter at breast height (total DBH), and combined duff and litter depth (cm; duff and litter depth). Imidacloprid variables included total treated tree diameter at breast height (Tx Tree DBH) and treatment presence (a categorical variable representing whether the site was in a treated or non-treated area; Tx Presence). Environmental and imidacloprid variables were standardized prior to analyses. The interceptonly model is represented by ( . ). We ranked each candidate predictor using Akaike's Information Criterion corrected for small sample size ( $\triangle \mathrm{AIC} c)$ and included additive (+) and interaction $(\mathrm{x})$ candidate models in the model selection for the two most supported environmental predictors.

\begin{tabular}{|c|c|c|c|c|}
\hline Model & Parameters & $\mathbf{A I C} c$ & $\Delta \mathrm{AIC} c$ & $w_{i}$ \\
\hline \multicolumn{5}{|c|}{ Environmental Model Selection } \\
\hline$()$. & 2 & -64.59 & 0.00 & 0.27 \\
\hline Total DBH & 3 & -63.93 & 0.66 & 0.20 \\
\hline Soil Moisture & 3 & -63.56 & 1.03 & 0.16 \\
\hline Total DBH + Soil Moisture & 4 & -62.33 & 2.26 & 0.09 \\
\hline Duff and Litter Depth & 3 & -62.24 & 2.35 & 0.08 \\
\hline Soil pH & 3 & -62.20 & 2.38 & 0.08 \\
\hline Canopy & 3 & -62.20 & 2.39 & 0.08 \\
\hline Total DBH x Soil Moisture & 5 & -59.80 & 4.79 & 0.02 \\
\hline \multicolumn{5}{|l|}{ Imidacloprid Model Selection } \\
\hline$()$. & 2 & -64.59 & 0.00 & 0.46 \\
\hline Tx Presence & 3 & -63.96 & 0.62 & 0.34 \\
\hline Tx Tree DBH & 3 & -62.99 & 1.59 & 0.21 \\
\hline Variables & $\beta$ & SE & $85 \%$ & \\
\hline \multicolumn{5}{|l|}{ (. ) + Tx Presence } \\
\hline Intercept & 0.05 & 0.02 & \multicolumn{2}{|c|}{$0.02-0.09$} \\
\hline Tx Presence & -0.04 & 0.03 & \multicolumn{2}{|c|}{$-0.09-0.01$} \\
\hline \multicolumn{5}{|l|}{ (. ) + Tx Tree $D B H$} \\
\hline Intercept & 0.03 & 0.02 & \multicolumn{2}{|c|}{$0.01-0.06$} \\
\hline Tx Tree DBH & -0.01 & 0.02 & \multicolumn{2}{|c|}{$-0.04-0.01$} \\
\hline
\end{tabular}




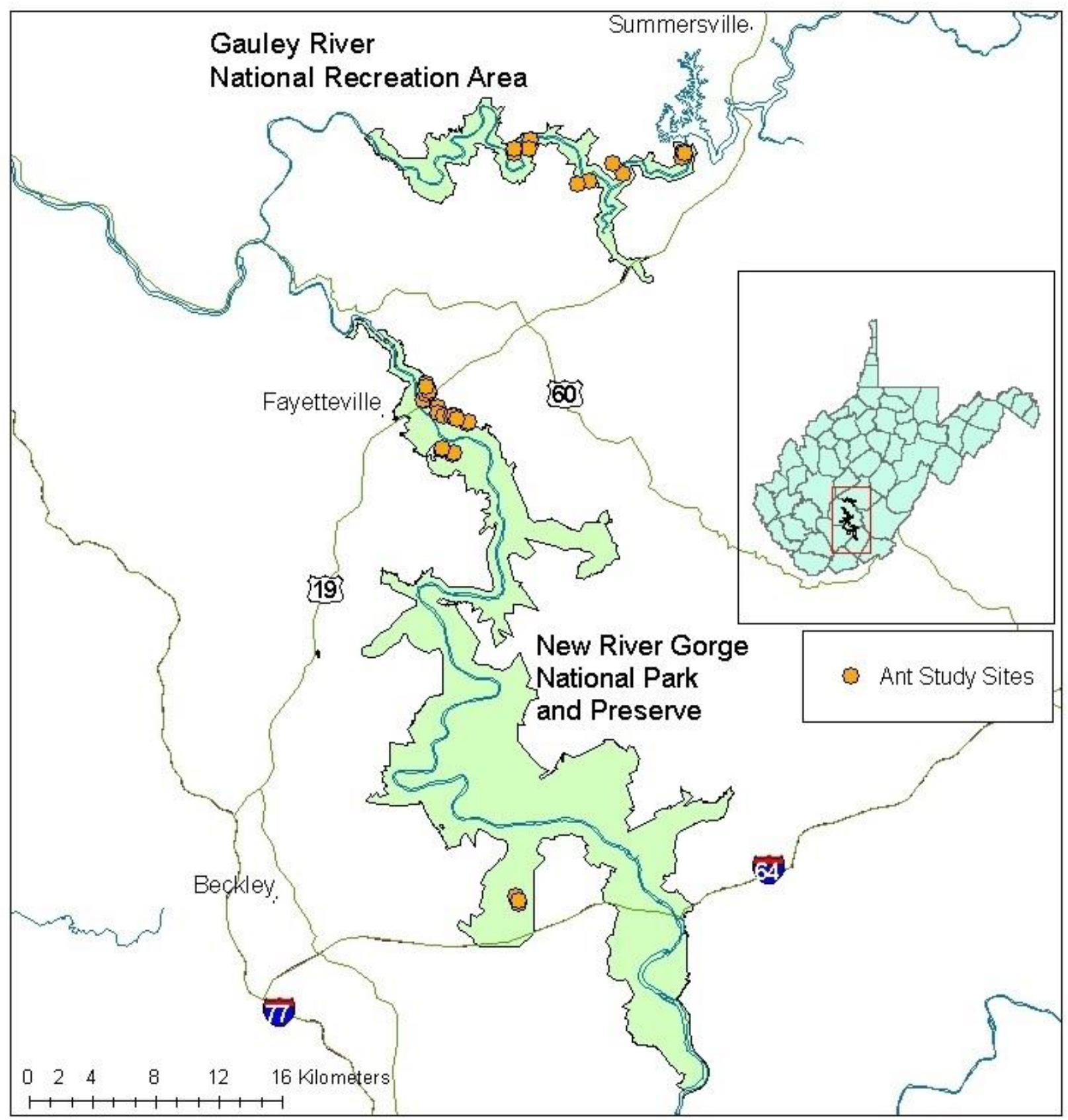

Figure 3-1. Map of imidacloprid study sites used in this study investigating potential effects of imidacloprid on ant species relative abundance and diversity in eastern hemlock (Tsuga canadensis) forests in Gauley River National Recreation Area and New River Gorge National Park and Preserve, West Virginia, USA. There were 18 sites consisting of a treatment plot and a control plot, for a total of 36 plots sampled three times in 2020. 


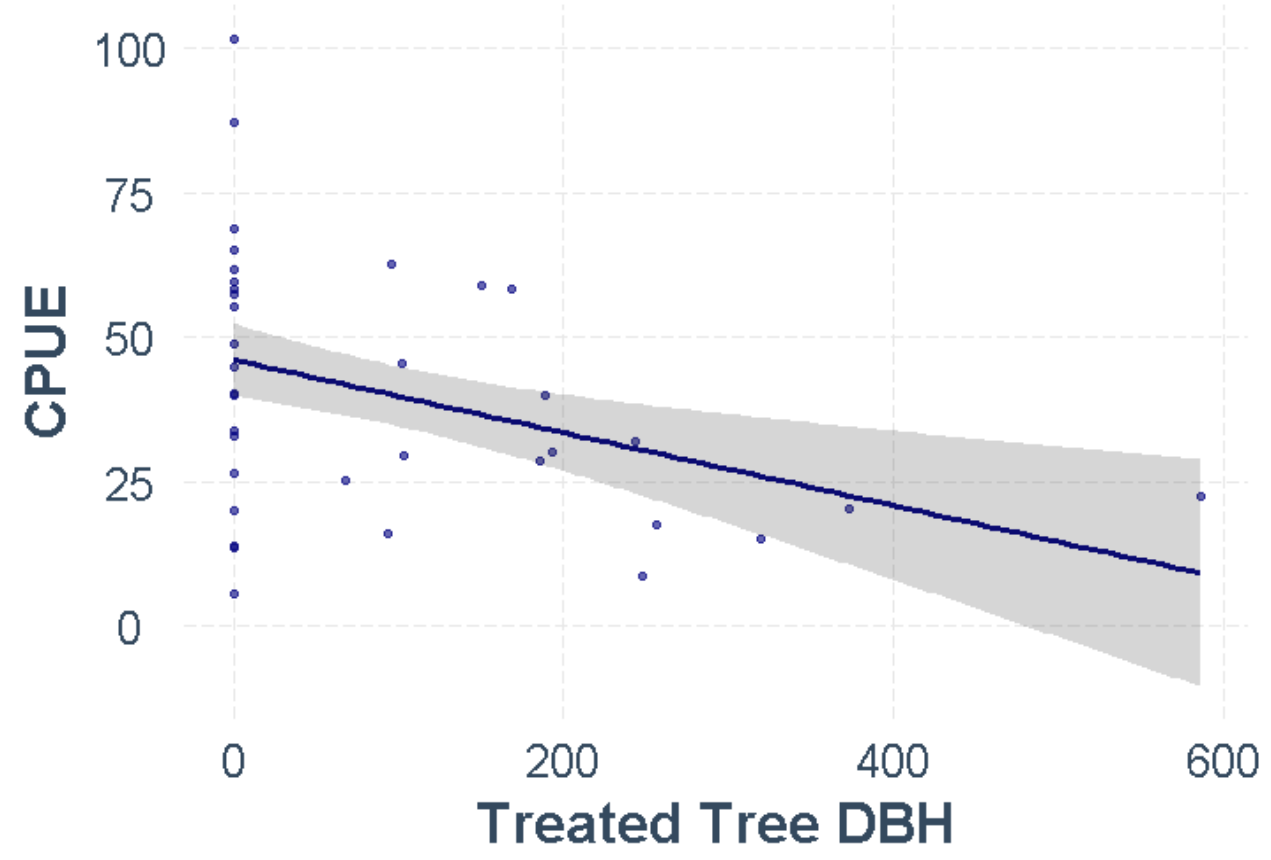

Figure 3-2. Model-estimated influence of treated tree diameter at breast height (DBH) on Aphaenogaster picea captures-per-unit effort (CPUE) in untreated and treated eastern hemlock (Tsuga canadensis) plots in Gauley River National Recreation Area and New River Gorge National Park and Preserve, West Virginia, USA. The variable total treated tree DBH was standardized prior to analyses, but is displayed in its original units in the figure. The gray band represents the $85 \%$ confidence interval of the estimated relationship. 


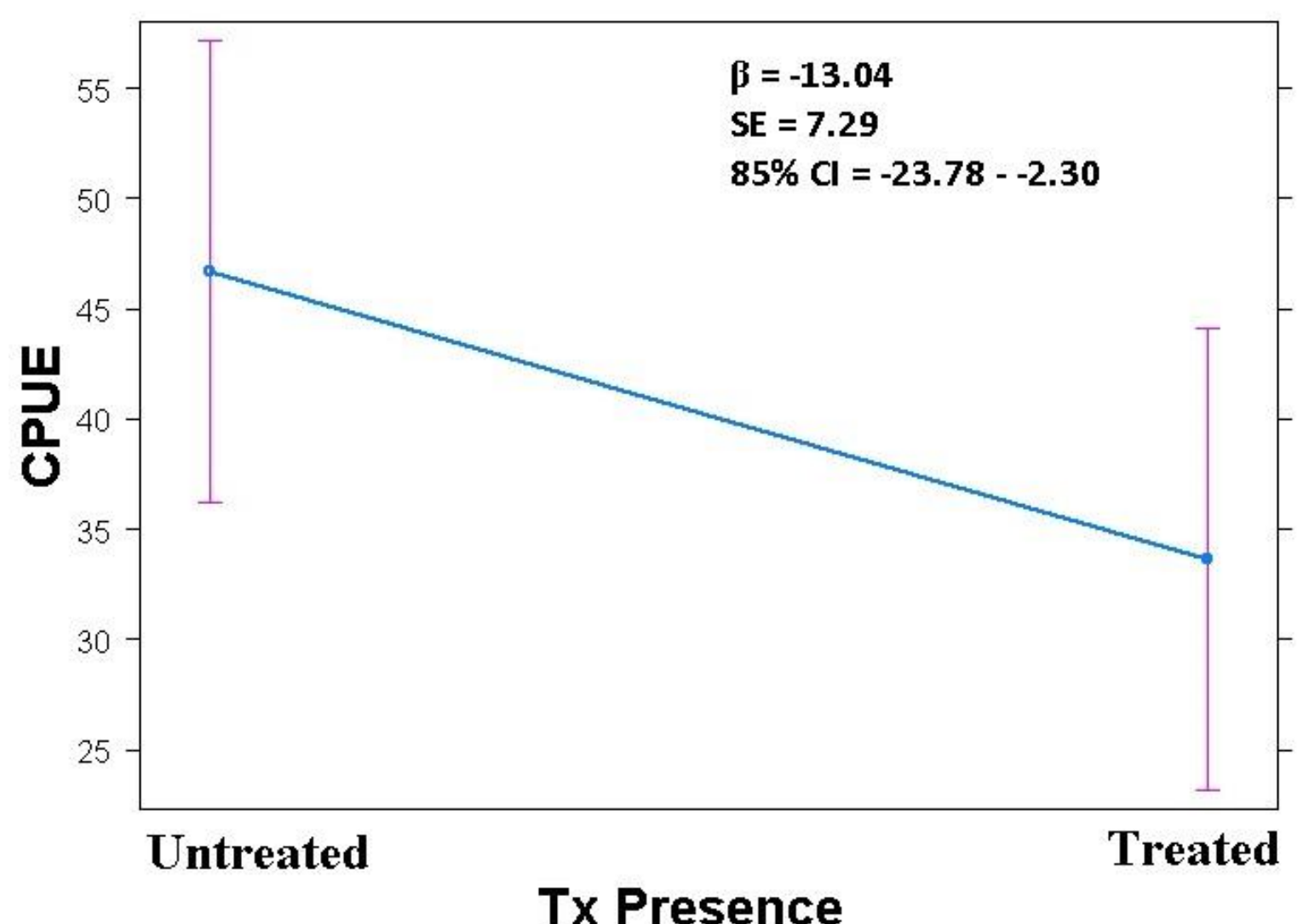

Figure 3-3. Model-estimated influence of imidacloprid treatment presence (Tx Presence) on Aphaenogaster picea captures-per-unit effort (CPUE) in untreated and treated eastern hemlock (Tsuga canadensis) plots in Gauley River National Recreation Area and New River Gorge National Park and Preserve, West Virginia, USA. We calculated CPUE by dividing total captures by number of subplot samples per plot. 


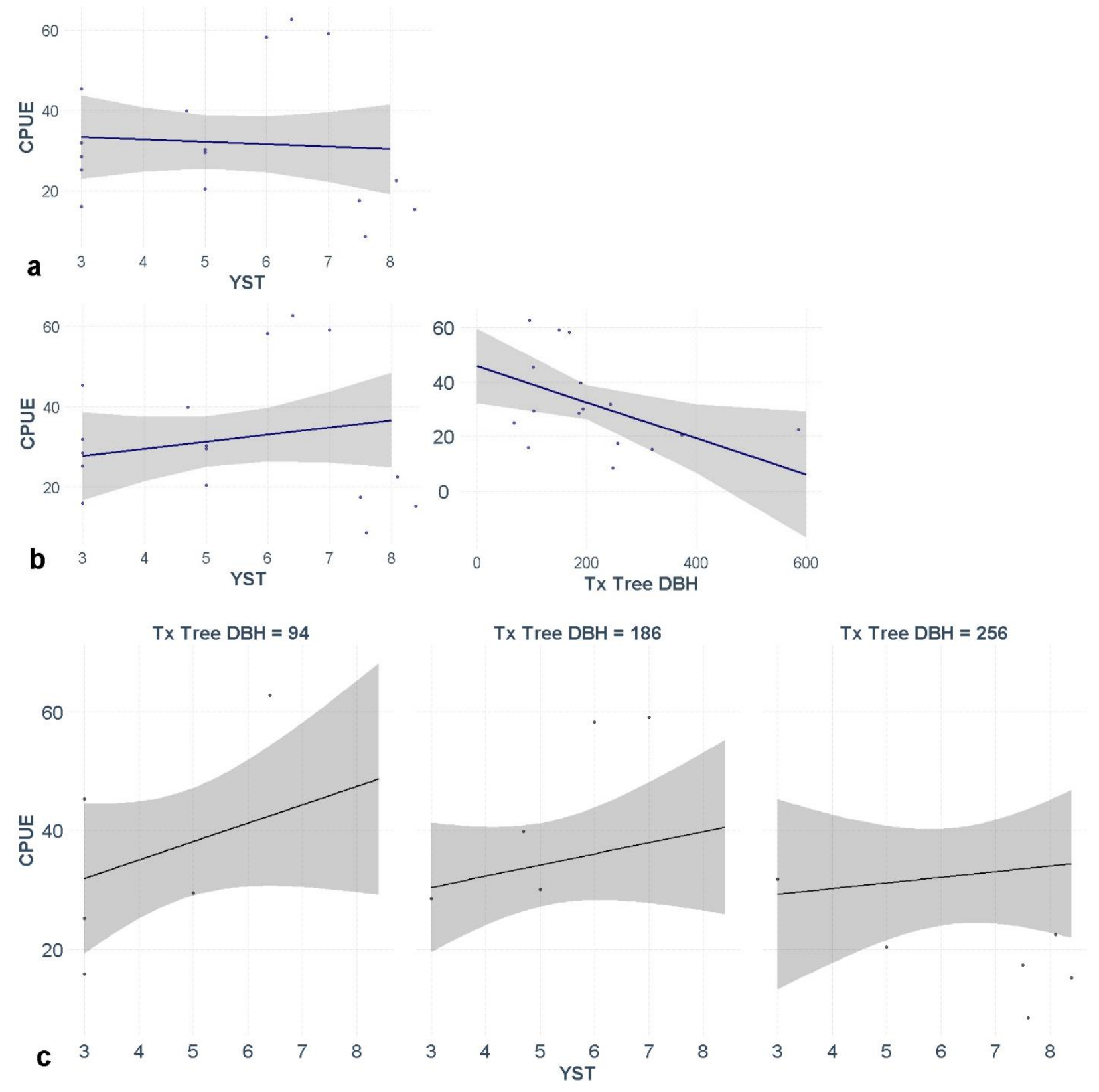

Figure 3-4. Model-estimated relationship of the effects of years since treatment (YST) and treated tree diameter at breast height $(\mathrm{Tx}$ Tree $\mathrm{DBH} ; \mathrm{cm})$ on Aphaenogaster picea captures-perunit-effort (CPUE) in eastern hemlock (Tsuga canadensis) plots treated with imidacloprid in Gauley River National Recreation Area and New River Gorge National Park and Preserve, West Virginia, USA, including: a) estimated relationship between CPUE and YST without accounting for Tx Tree DBH; b) estimated relationship between CPUE and YST and CPUE and Tx Tree DBH (additive effect); c) estimated relationship between CPUE and YST at the mean $(186 \mathrm{~cm})$ and $+/-1$ standard deviation of all plot Tx Tree DBH sizes (interaction effect). Imidacloprid variables were standardized prior to analyses, but are displayed in their original units in the figure. The gray bands represents the $85 \%$ confidence interval of the estimated relationships. 